SLAC-R-555

\title{
Annual Site Environmental Report
}

\author{
January- December 1999
}

Prepared for the Department of Energy

under contract number DE-AC 03-76SF00515

Environment, Safety, and Health Division

August 2000

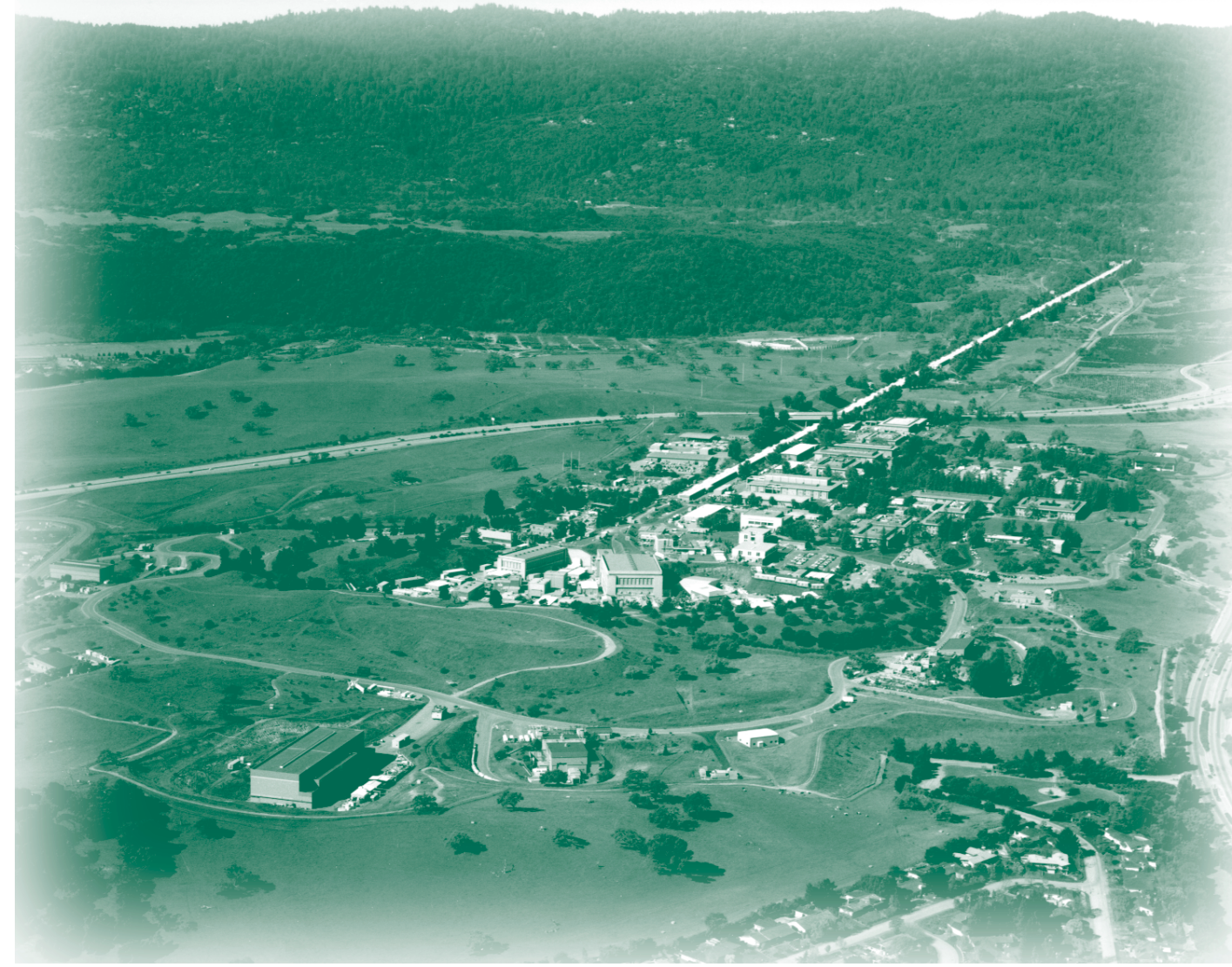

STAN FO RD LIN EAR ACCELERATO R CENTER 
This document and the material and data contained therein, was developed under sponsorship of the U nited States G overnment. N either the U nited States nor the Department of Energy, nor the Leland Stanford Junior University, nor their employees, makes any warranty, express or implied, or assumes any liability or responsibility for accuracy, completeness or usefulness of any information, apparatus, product or process disclosed, or represents that its use will not infringe privately-owned rights. Mention of any product, its manufacturer, or suppliers shall not, nor is it intended to, imply approval, disapproval, or fitness for any particular use. A royalty-free, non-exclusive right to use and disseminate same for any purpose whatsoever, is expressly reserved to the U nited States and the U niversity. 


\section{Site Environmental Report \\ Calendar Year 1999 \\ (January- December)}

\section{ENVIRO N MENT, SAFETY, \\ AND \\ HEALTH DIVISION}

\section{SLAC Report 555}

August 2000

Prepared for the Department of Energy under contract number DE-AC03-76SF00515

STAN FO RD LIN EAR ACCELERATO R CENTER

Stanford U niversity Stanford, California 


\section{Authors}

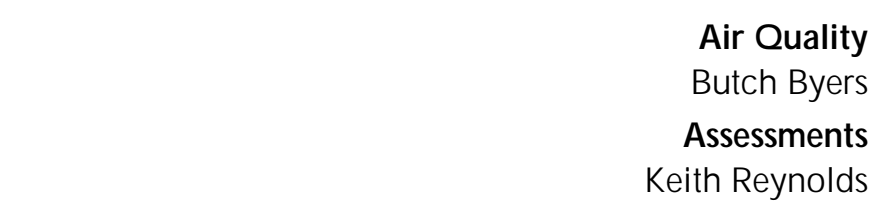

Environmental Restoration and Groundwater Programs

Helen Nuckolls

Industrial Wastewater, Environmental Programs, Community Relations

Kirk Stoddard

Hazardous Material Business Plan

Valerie Stone

Incidents and Releases, Surface and Stormwater

Michael Hug

Q uality Assurance

Jack Hahn

Radiological Program

Tom G wise

Ken Kawabata

Q uang Le

Roger Sit

W aste Management

Michael Scharfenstein

W aste Minimization

Rich Cellamare

\section{Contributors}

Environmental Restoration, G raphics, Illustrations, Maps, and Publication

Terry Anderson

Michelle Decamara

Jeremy N elson

Dellilah Sabba

Crystal Tighlman

Susan W itebsky

\section{Coordinators}

Helen Nuckolls Mike G rissom Editor 


\section{Table of Contents}

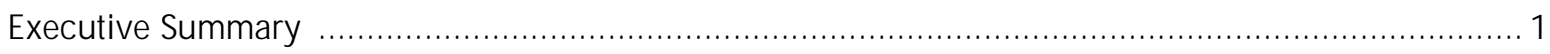

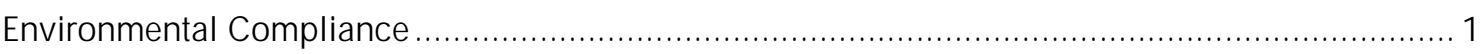

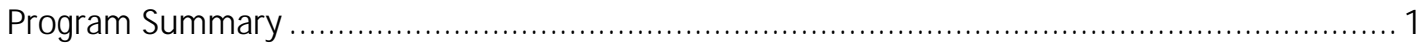

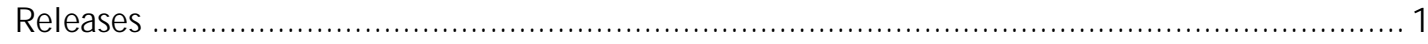

Environmental N on-Radiological Program ..................................................................... 1

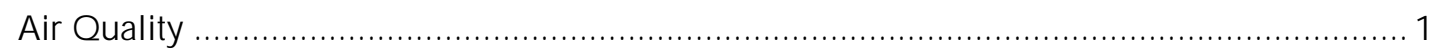

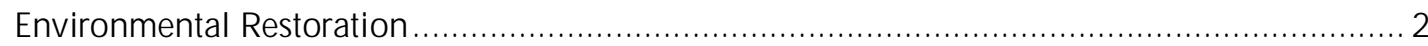

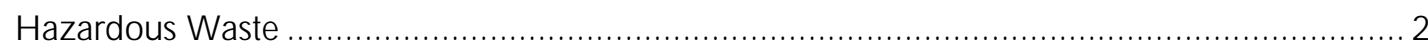

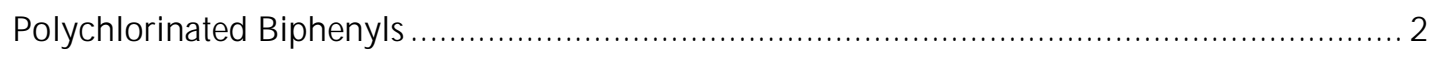

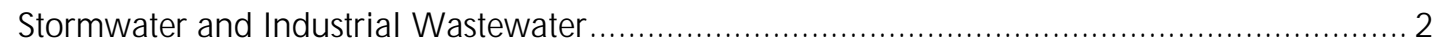

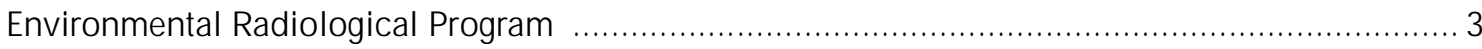

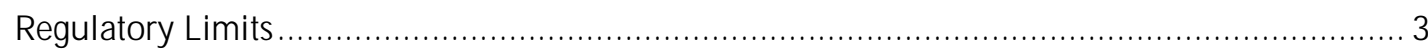

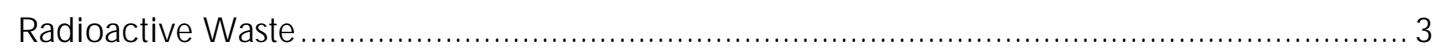

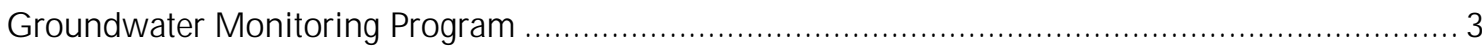

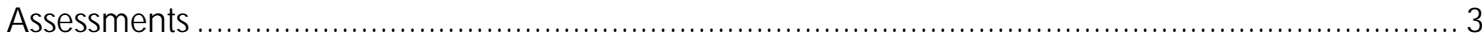

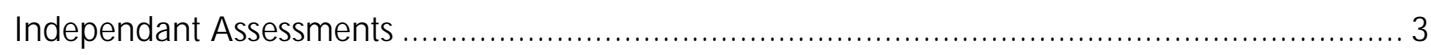

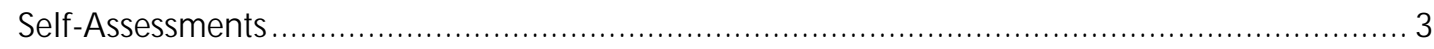

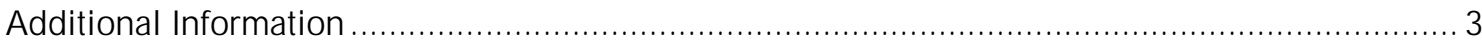

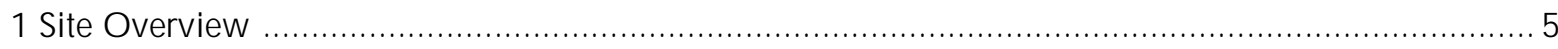

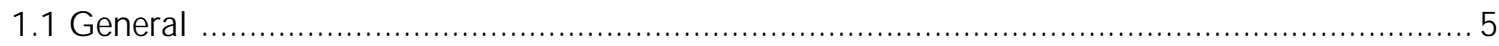

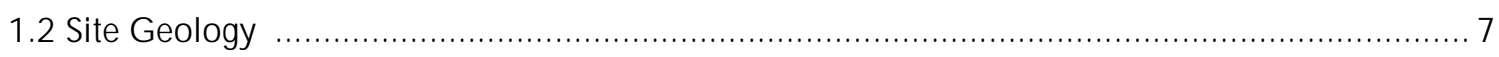

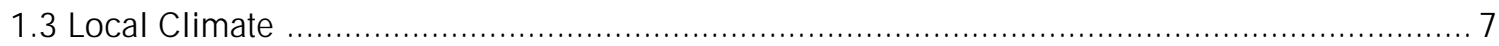

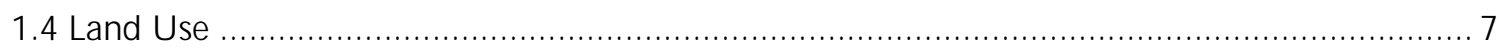

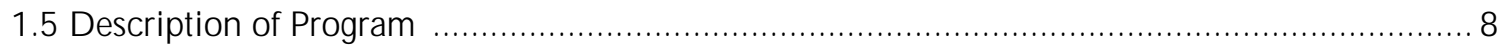

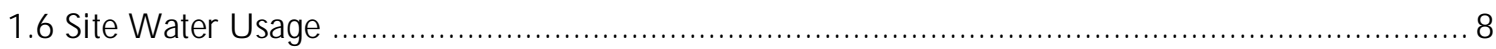

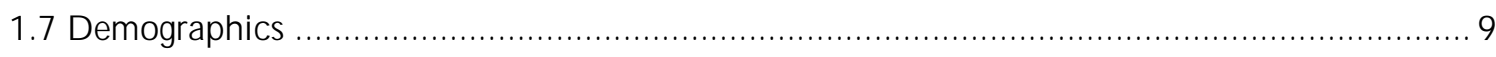

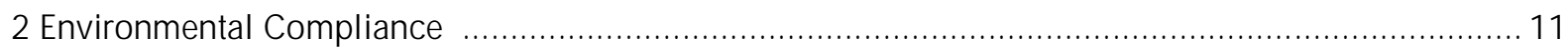

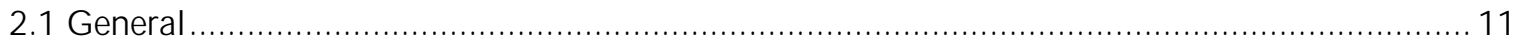

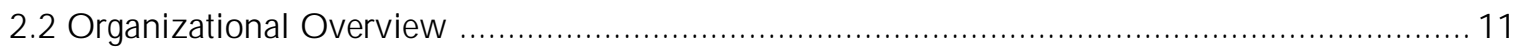

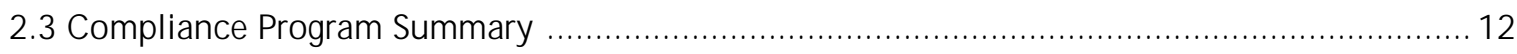

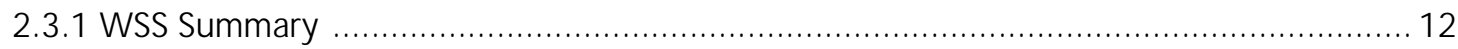

2.3.2 Safety M anagement System Summary ……….................................................. 12

2.3.3 Environmental Permits Summary (Table) ……………………………………….... 13

2.3.4 Assessments, Inspections, and Q uality Assurance Summaries ................................. 14 


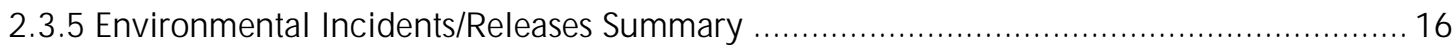

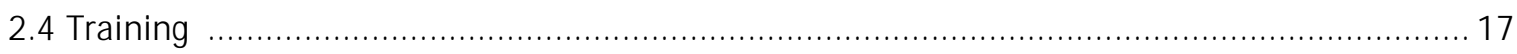

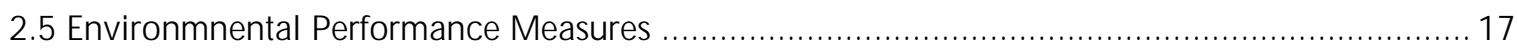

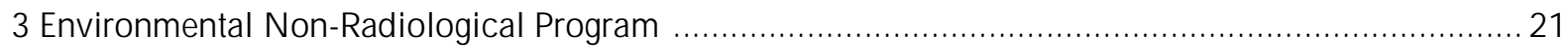

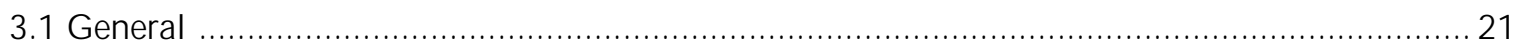

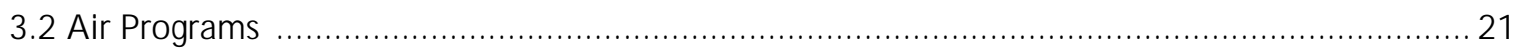

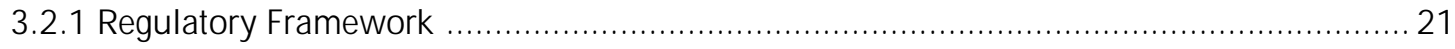

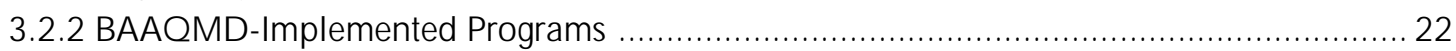

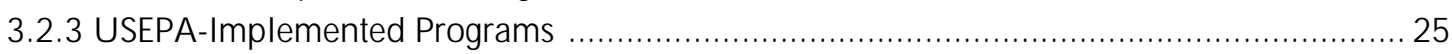

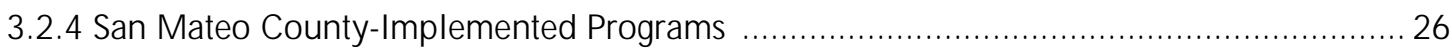

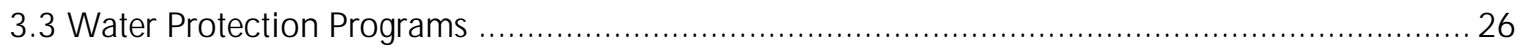

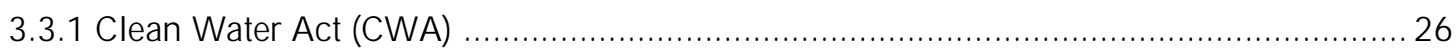

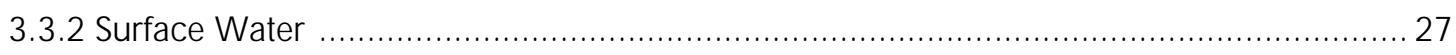

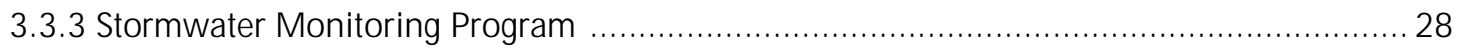

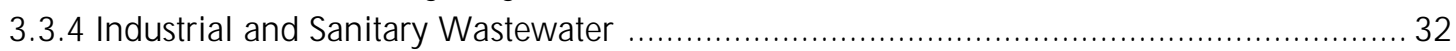

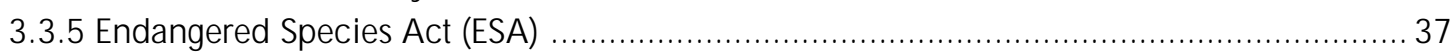

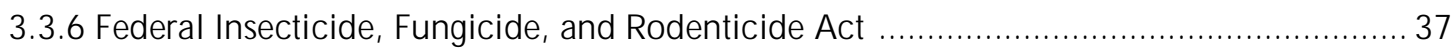

3.3.7 Executive O rder 11990, "Protection of W etlands" ..................................................... 39

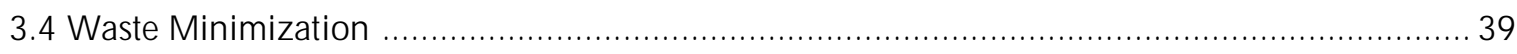

3.4.1 Site-W ide Program Planning and Development .............................................. 39

3.4.2 W aste Minimization and Pollution Prevention

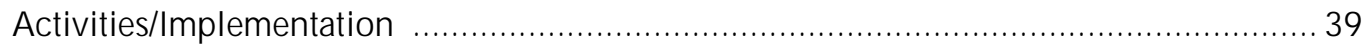

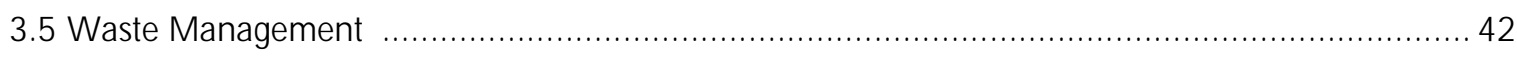

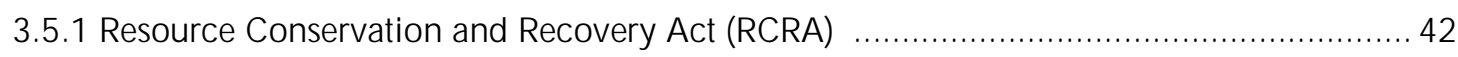

3.5.2 Waste Prevention, Recycling, and Federal Acquisition ........................................ 44

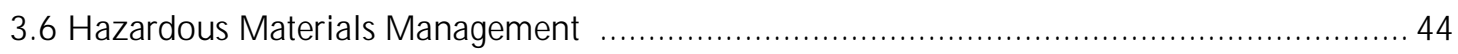

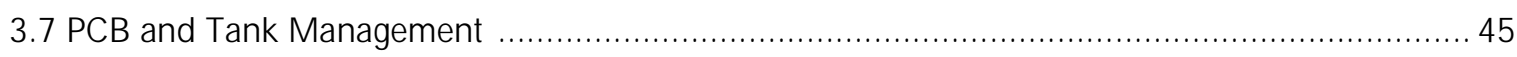

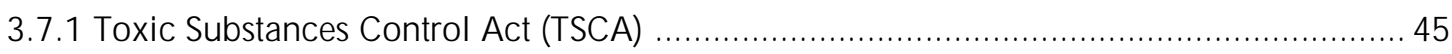

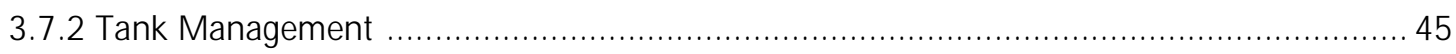

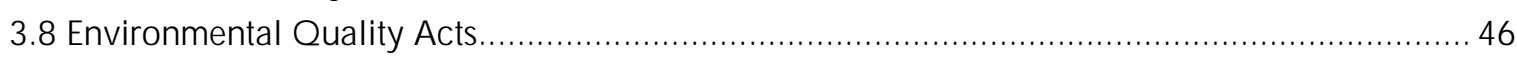

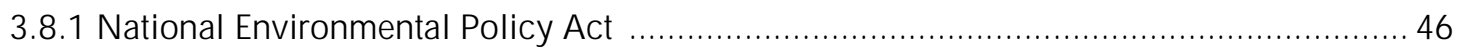

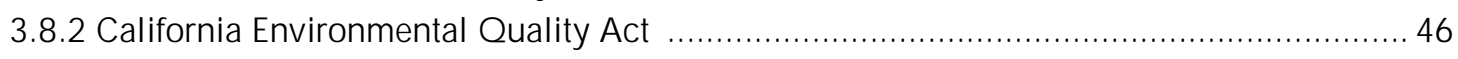

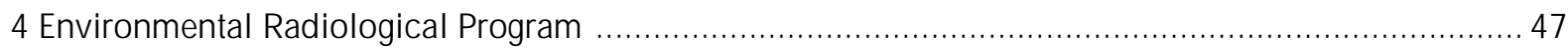

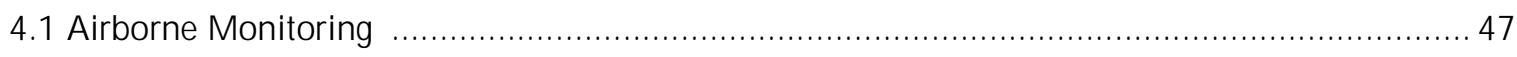

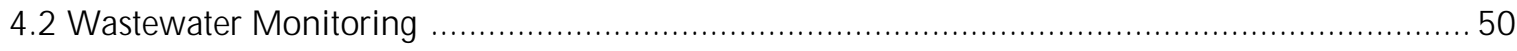

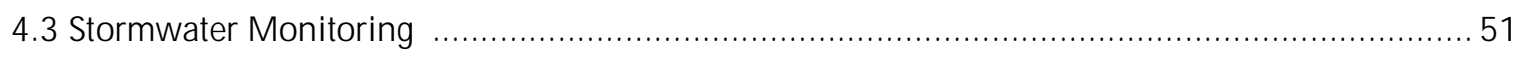

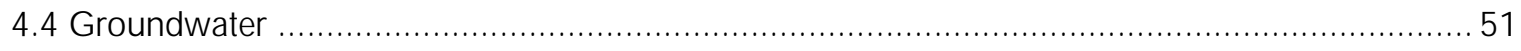

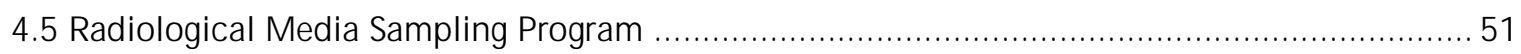

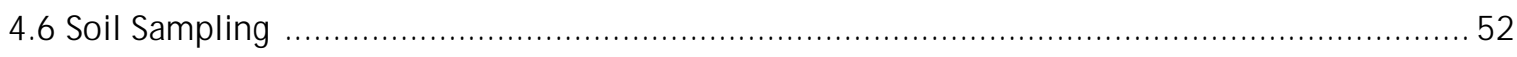

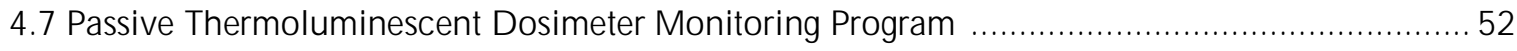

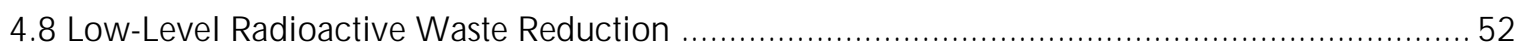




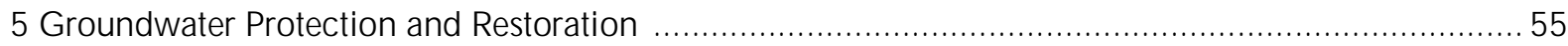

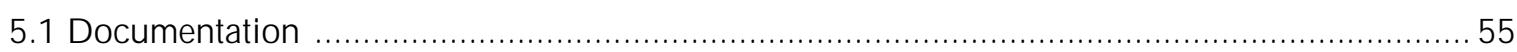

5.2 Identification and Summary of Potentially Contaminated Areas.............................................. 56

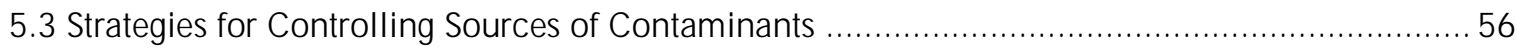

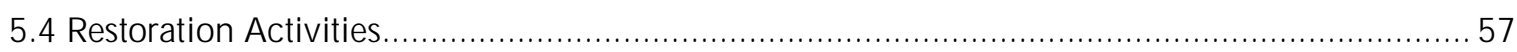

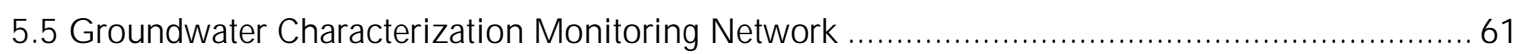

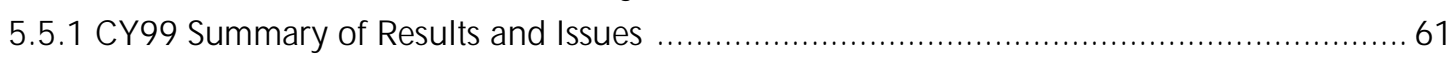

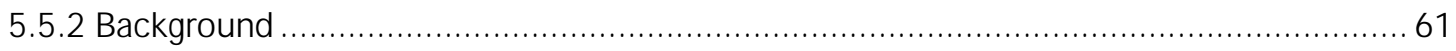

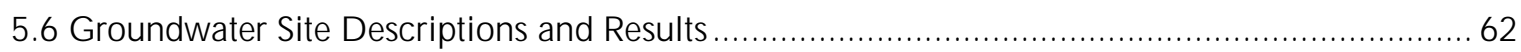

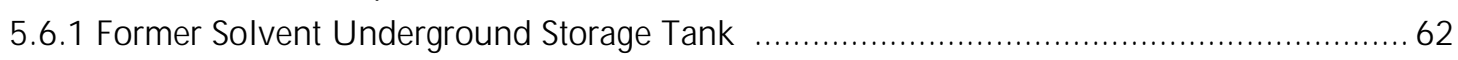

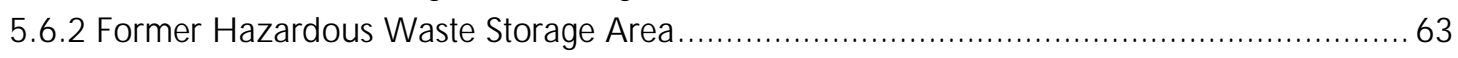

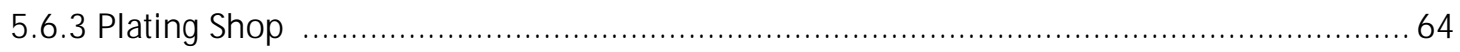

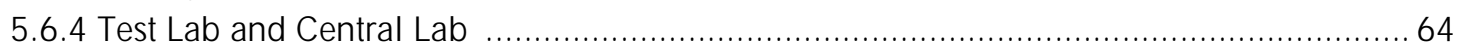

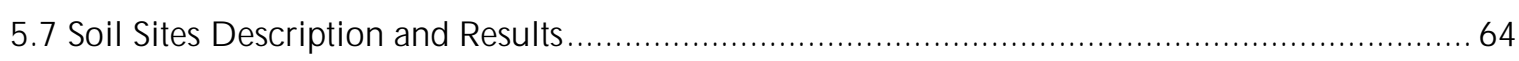

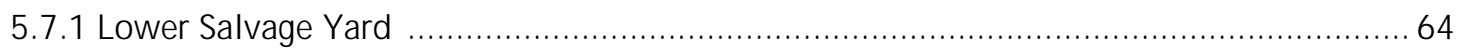

5.7.2 IR-6 Drainage Channel and Research Yard Investigation and Remediation .................... 65

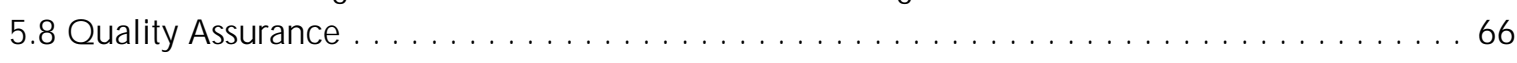

Appendices

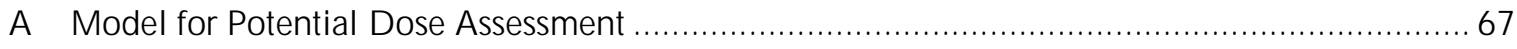

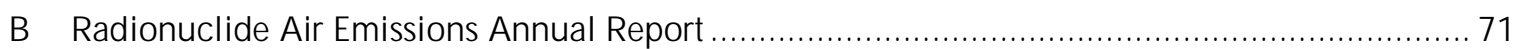

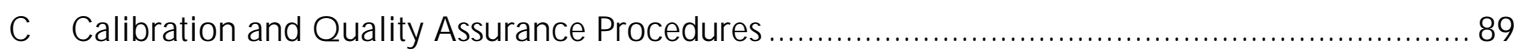

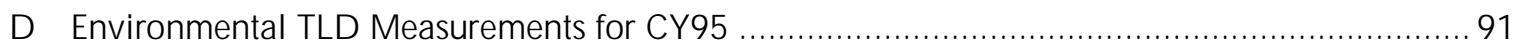

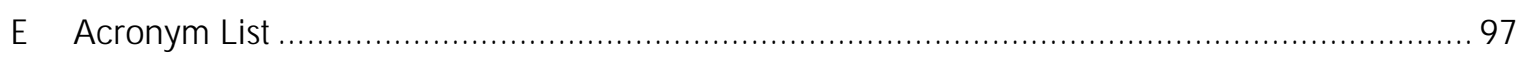

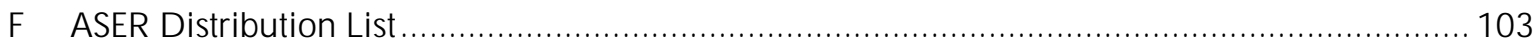

ASER Reader Survey 
Figures

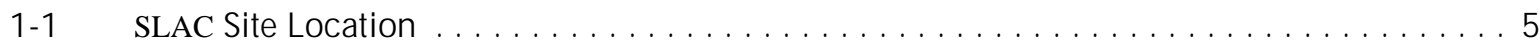

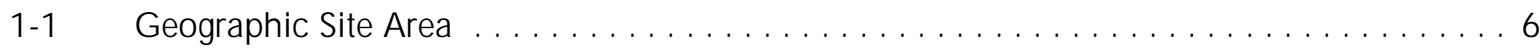

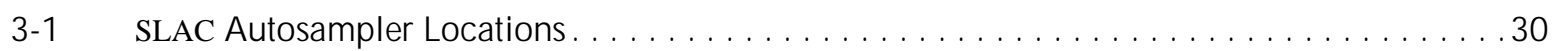

3-2 Facility Map Showing San Francisquito Creek $\ldots \ldots \ldots \ldots \ldots \ldots \ldots \ldots \ldots \ldots \ldots \ldots \ldots$

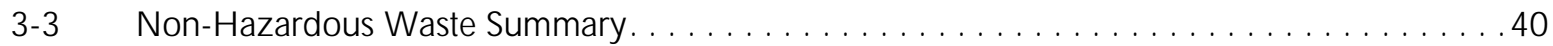

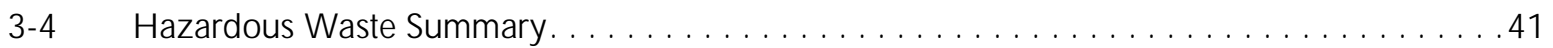

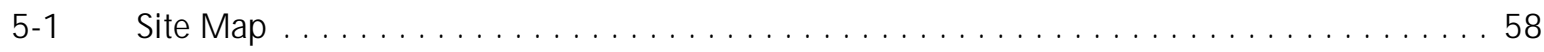

5-2 Location of W estern Groundwater Monitoring W ell N etwork and Areas with $\mathrm{G}$ roundwater Contamination . . . . . . . . . . . . . . . . . . . . 59

5-3 Location of Eastern Groundwater M onitoring W ell N etwork and Areas with $\mathrm{G}$ roundwater Contamination . . . . . . . . . . . . . . . . . . . . 60

A-1 Neutron Measurements Made Along a Line Between End Station A and the

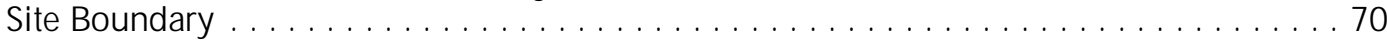

D-1 Environmental TLD Monitoring Stations, Sectors 0 through $12 \ldots \ldots \ldots \ldots \ldots \ldots$

D-2 Environmental TLD Monitoring Stations, Sectors 12 through $27 \ldots \ldots \ldots \ldots \ldots \ldots$

D-3 Environmental TLD Monitoring Stations, Sector 27 through SLC $\ldots \ldots \ldots \ldots \ldots \ldots$ 
1-1 Demographic Data . . . . . . . . . . . . . . . . . . . . 9

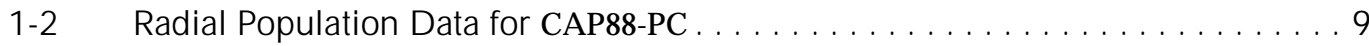

2-1 General Permits and Notifications $\ldots \ldots \ldots \ldots \ldots \ldots \ldots \ldots \ldots \ldots \ldots \ldots \ldots$

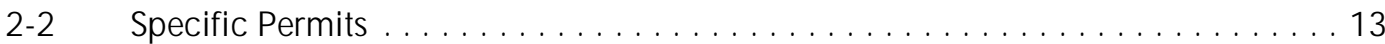

2-3 Enforcement Inspections....................... 14

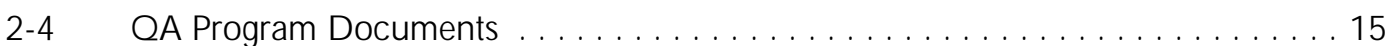

2-5 Environmental Incidents/Releases summary $\ldots \ldots \ldots \ldots \ldots \ldots \ldots \ldots \ldots$

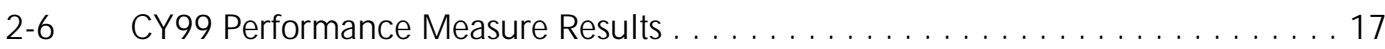

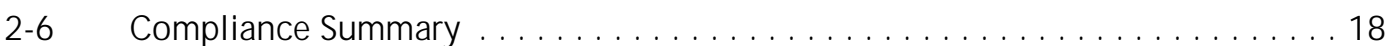

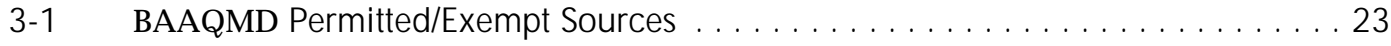

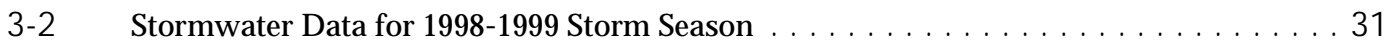

3-3 CY99 Flow Meter Station Sampling Data (First Half) $\ldots \ldots \ldots \ldots \ldots \ldots \ldots \ldots \ldots$

3-4 CY99 Flow Meter Station Sampling Data (Second Half) $\ldots \ldots \ldots \ldots \ldots \ldots \ldots . \ldots . \ldots$

3-5 CY99 Rinse Water Treatment Plant Sampling Data $\ldots \ldots \ldots \ldots \ldots \ldots \ldots$

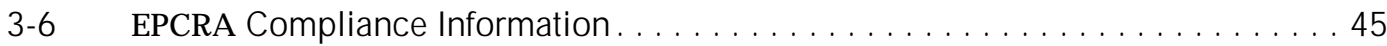

4-1 Radioactive Gases Related to Atmosphere $\ldots \ldots \ldots \ldots \ldots \ldots \ldots \ldots \ldots$

4-2 Summary of Annual Effective Dose Equivalents due to 1999 Laboratory 0 perations ............................... 49

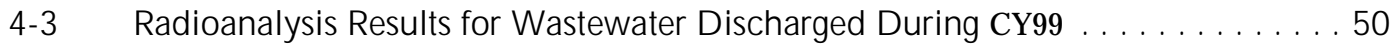

4-4 History of Radioactivity Discharged $\ldots \ldots \ldots \ldots \ldots \ldots \ldots \ldots \ldots \ldots \ldots \ldots \ldots$

5-1 Purpose and Location of Monitoring Wells................... 62 


\section{Appendix B (NESHAPs)}

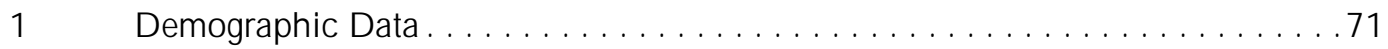

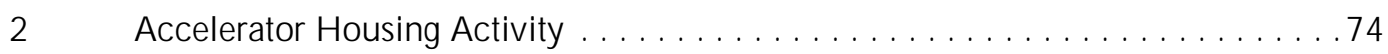

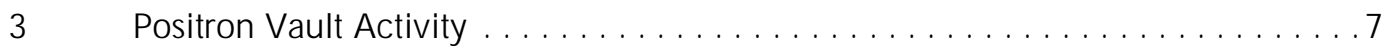

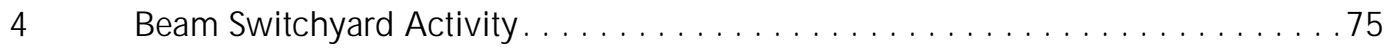

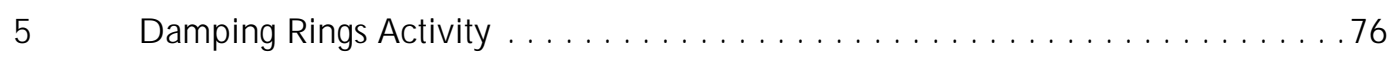

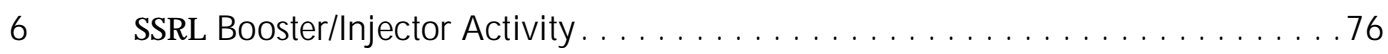

$7 \quad$ Final Focus Test Beam Activity $\ldots \ldots \ldots \ldots \ldots \ldots \ldots \ldots \ldots \ldots \ldots \ldots \ldots \ldots \ldots \ldots$

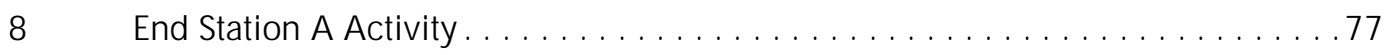

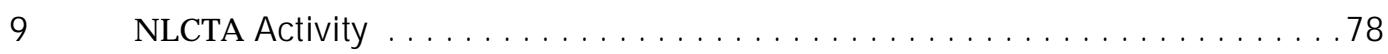

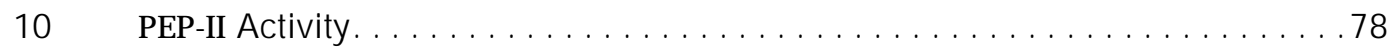

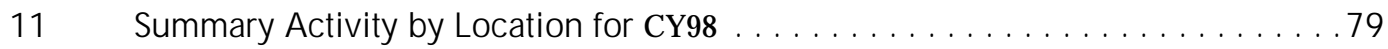

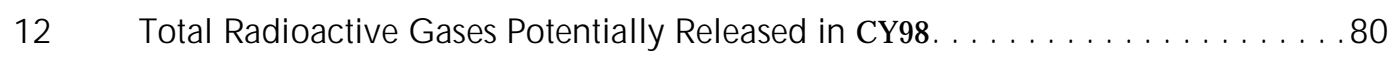

13 Determination of Maximally Exposed Individual. . . . . . . . . . 83

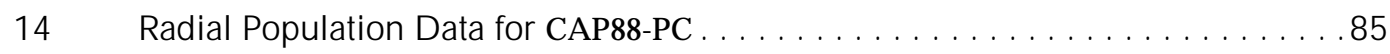

\section{Appendix D}

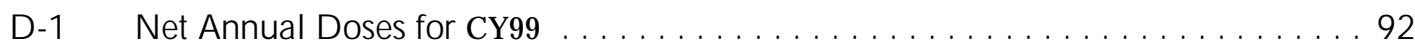




\section{Executive Summary}

This report provides information about environmental programs and compliance with environmental regulations in calendar year 1999 (CY99) at the Stanford Linear Accelerator Center (SLAC). The most noteworthy information in this report is summarized in this section.

\section{Environmental Compliance}

Section 2 contains the complete Environmental Compliance information.

\section{Program Summary}

In CY99, SLAC operated under the Work Smart Standards (WSS) Set, which are incorporated in SLAC's Management and Operating contract. The WSS Set includes all applicable statutory and regulatory requirements for public and worker safety and environmental protection. The WSS Set also includes a number of industry standards that were found to be necessary to control specific hazards present at SLAC.

\section{Releases}

Air

No notices of violation (NOVs) or notices to comply (NTCs) were received from the Bay Area Air Quality Management District (BAAQMD) during CY99.

\section{Industrial W astewater}

No wastewater discharge permit violations occurred during CY99.

\section{Stormwater}

Four accidental releases entered the storm drain system. The Regional Water Quality Control Board (RWQCB) was notified of these releases as appropriate. The materials released included untreated sewage and domestic water.

All four releases were determined to represent minimal or negligible risk. To identify corrective actions for the site-wide sanitary sewer system, an assessment was completed in CY99. Funding has been requested to repair the highest priority areas.

\section{Environmental Non-Radiological Program}

Section 3 contains the bulk of the environmental non-radiological information. Section 5 contains the bulk of the groundwater program information.

\section{Air Q uality}

A total of 20 air emission sources were included in the SLAC Permit to Operate from the Bay Area Air Quality Management District (BAAQMD) at year-end. Five permit applications were pending at year-end. BAAQMD conducted an annual inspection of SLAC on June 3, 1999. No instances of noncompliance were noted. All permitted emission sources were operated in compliance with their respective emissions limitations in CY99. 
During 1999, BAAQMD revised its regulations implementing Title V of the Clean Air Act. As a result, SLAC became subject to the Title V permitting program and is required to take one of the following actions by October 20, 2000:

- Apply for a Major Facility Review Permit

- Demonstrate that the SLAC "potential to emit" is below the major facility thresholds defined in BAAQMD Regulation 2-6-312

- Apply for and receive a Synthetic Minor Operating Permit (SMOP).

Accordingly, SLAC conducted Phase One of a baseline air emissions inventory and formed a "Chemical Use Tracking Work Group" with a charter to recommend a chemical information system suitable for supporting a Title V program. Phase Two of the baseline air emissions inventory, and a decision as to which of the above actions SLAC plans to take to meet its Title V compliance obligation, are anticipated to be completed by April 2000.

SLAC is expecting that the San Mateo County Department of Health Services (the County) will initiate a dialogue in either CY00 or CY01 regarding the California Accidental Release Prevention Program (CalARP) requirements that will be applied to SLAC.

\section{Environmental Restoration}

As a part of the SLAC, the Environmental Protection and Restoration (EPR) Department, the Environmental Restoration Program continued work on site characterization and evaluation of remedial alternatives at four sites with detected volatile organic compounds (VOCs) in groundwater. In addition, EPR continued active participation in various public activities throughout the year.

\section{H azardous Waste}

The San Mateo County Division of Environmental Health conducted a Permit-by-Rule Inspection from March through November 1999. The report states: "No violations noted."

SLAC complied with all waste management requirements for disposal of hazardous waste in CY99 as required under federal, state, and local regulations. During CY99, all hazardous waste for off-site disposal was successfully shipped from SLAC within 90 days of generation.

\section{Polychlorinated Biphenyls}

SLAC has some equipment filled with oil or other dielectric fluids which contain Polychlorinated Biphenyls (PCBS). In CY99, SLAC continued to reduce its inventory of PCBs by replacing or disposing of nearly half of the remaining PCB-containing transformers on site, as well as other PCB-containing equipment. SLAC will continue to remove, or retrofill and reclassify, the remaining 13 PCBcontaminated transformers over the next few years.

\section{Stormwater and Industrial Wastewater}

SLAC updated the Stormwater Pollution Prevention Plan in accordance with the new permit, which became effective on July 1, 1997. There were no sanitary sewer permit violations in CY99. Twelve illicit stormwater connections were eliminated in CY99.

SLAC completed four erosion control projects in CY99. Monitoring continued for both Stormwater and Industrial Wastewater programs. The results were tabulated in annual or semi-annual reports. All monitoring data indicated continued compliance with corresponding permit conditions. 


\section{Environmental Radiological Program}

Section 4 contains the complete Environmental Radiological information.

\section{Regulatory Limits}

SLAC monitors potential radiological releases to the environment through wastewater, air emissions, and direct radiation from accelerator operations. SLAC did not exceed regulatory limits for radioactivity released to the environment in CY99. In addition, there were no known instances of noncompliance for radionuclide air emissions in CY99.

\section{Radioactive Waste}

SLAC continues to manage its radioactive waste safely and in compliance with all applicable regulations. In addition, major efforts were put into projects during CY99 to clear the site of "legacy waste". Two thousand cubic feet of low-level radioactive waste was sorted, inventoried, characterized, and packaged for eventual disposal. A volume reduction of over $70 \%$ was achieved in the process. Another project involved the de-watering of 1,500 pounds of spent ion-exchange resin. This resin was later packaged and shipped to the Pacific Northwest National Laboratory (PNNL) in Hanford, Washington for disposal.

\section{G roundwater Monitoring Program}

The groundwater monitoring program at SLAC is managed through EPR. Groundwater samples were collected from monitoring wells for surveillance purposes, as well as to investigate the extent of VOCs in groundwater. Both hazardous substances and tritium are monitored under this program.

\section{Assessments}

\section{Independent Assessments}

Dames and Moore Quality Assurance (QA) environmental assessments were conducted in December of 1998. Safety related QA assessments were conducted in the second quarter of CY99. Environmental assessments are scheduled for the first quarter of 2000.

\section{Self-Assessments}

SLAC held its fourth annual Safety and Environmental (S\&E) Discussion on March 12, 1999. The discussions provided employees the opportunity to raise safety and environmental concerns.

Employee issues were entered into a database and tracked. Of the 165 issues raised, 57 were environmental. Fifty-nine tasks were developed to address the issues. As of December 31, 1999, 50 of the 59 tasks had been addressed.

\section{Additional Information}

A reader's survey has been provided at the end of this document. Additional information about SLAC is available at: http://www.slac.stanford.edu/. 


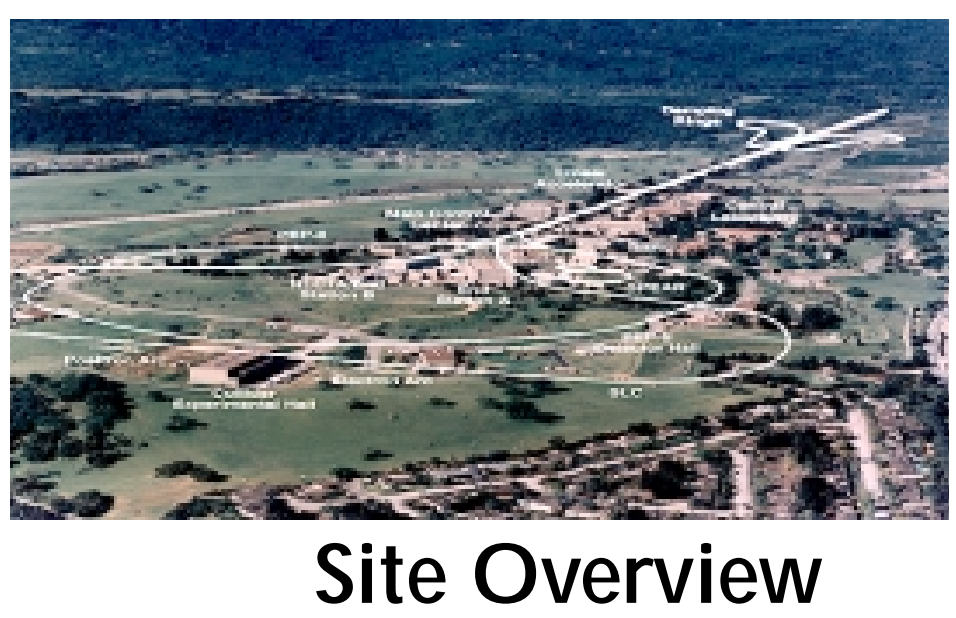

\section{$1.1 \quad$ General}

The Stanford Linear Accelerator Center (SLAC) is a national facility operated by Stanford University under contract with the Department of Energy (DOE). SLAC is located on the San Francisco Peninsula, about halfway between San Francisco and San Jose, California (see Figure 1-1).

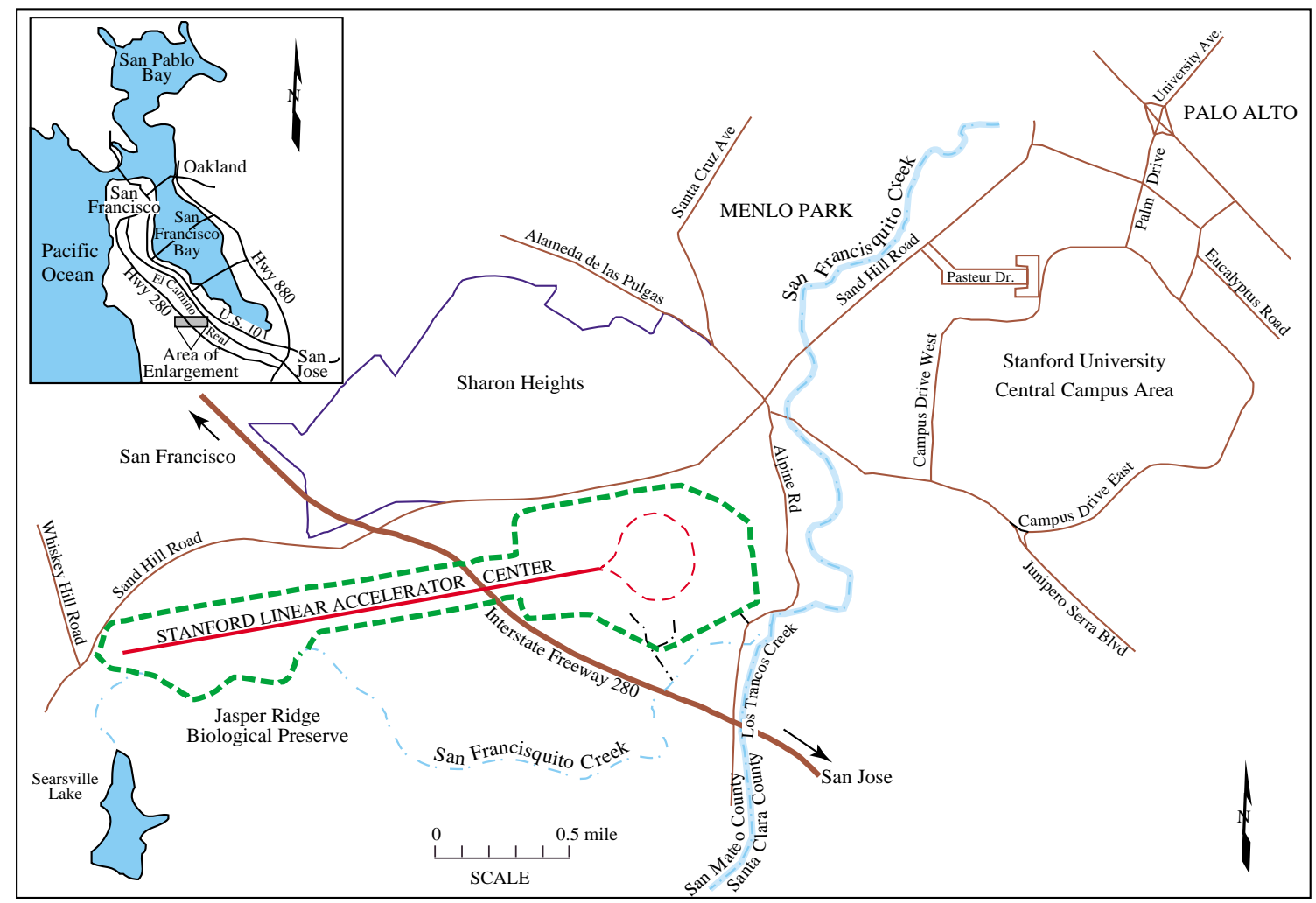

Figure 1-1 SLAC Site Location 
The site area is in a belt of low, rolling foothills lying between the alluvial plain bordering San Francisco Bay on the east and the Santa Cruz Mountains on the west. The accelerator site varies in elevation from 53 to 114 meters (m) above sea level. The alluvial plain to the east around the Bay lies less than $46 \mathrm{~m}$ above sea level; the mountains to the west rise abruptly to over $610 \mathrm{~m}$ (see Figure 1-2).

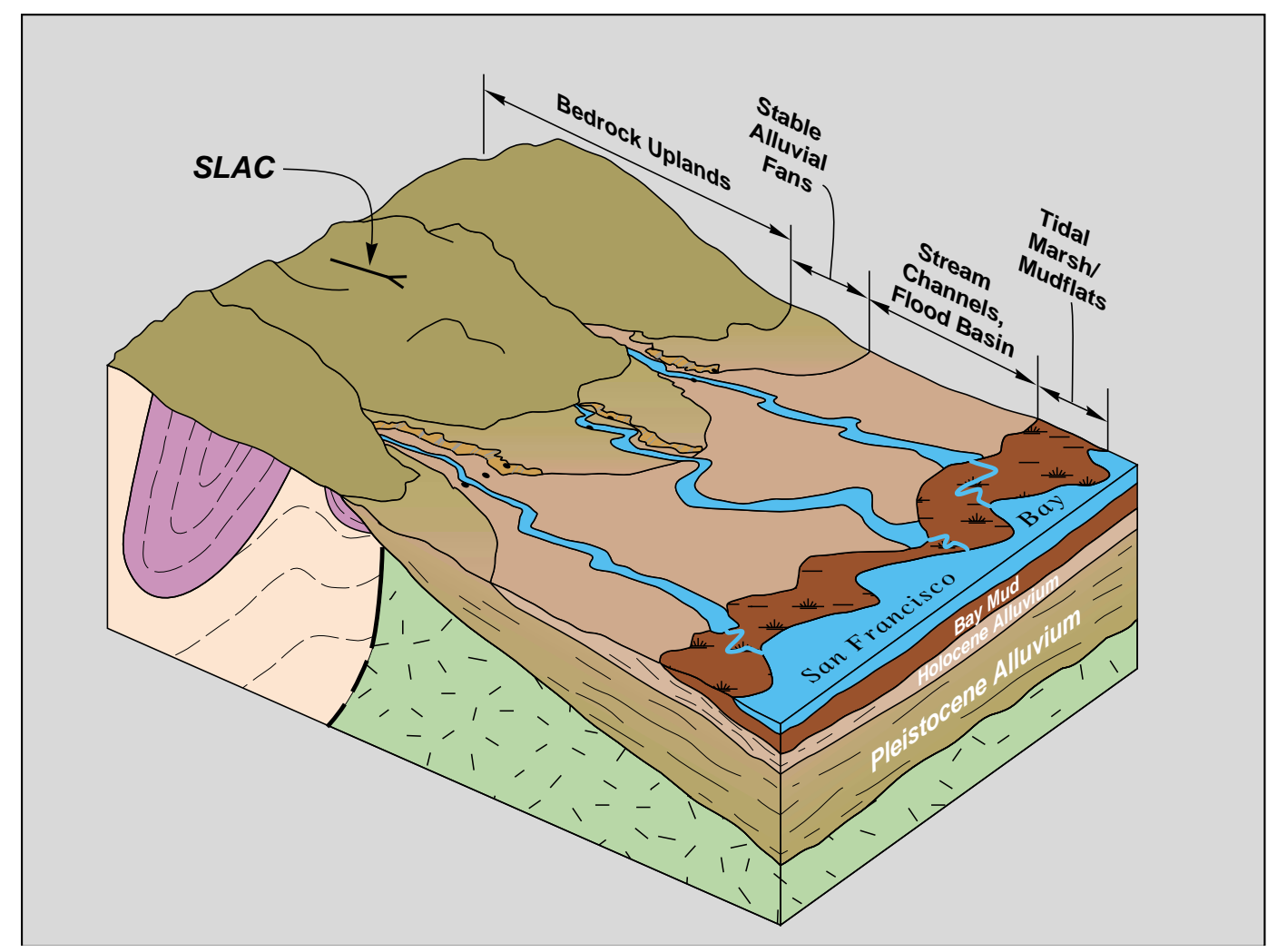

Figure 1-2 G eographic Site Area

The SLAC site occupies 170 hectares of land owned by Stanford University. The property was leased in 1962 for purposes of research in the basic properties of matter. The original lease to the Atomic Energy Commission (AEC), now DOE, was for fifty years. The lease was given for the purpose of researching the basic properties of matter. The land is part of Stanford's "academic reserve," and is located west of the University and the City of Palo Alto in an unincorporated portion of San Mateo County.

The site is bordered on the north by Sand Hill Road and on the south by San Francisquito Creek. The laboratory is located on a parcel roughly $300 \mathrm{~m}$-wide and 3.2 kilometers $(\mathrm{km})$ long, running in an east-west direction. The parcel widens to about $910 \mathrm{~m}$ at the target (east) end to allow space for buildings and experimental facilities.

The SLAC population currently numbers about 1,350 people, of which 150 are $\mathrm{Ph} . \mathrm{D}$. physicists. Approximately 800 staff members are professional, composed of physicists, engineers, programmers, and other scientific-related personnel. The balance of the staff is composed of support personnel including technicians, crafts personnel, laboratory assistants, and administrative associates. In addition to the regular population, at any given time there are between 900 and 1,000 visiting scientists. 


\subsection{Site G eology}

The SLAC site is underlain by sandstone, with some basalt at the far eastern end of the site boundary. In general, the bedrock on which the western half of the SLAC linac rests is the Whiskey Hill Formation (Eocene age), and the bedrock under the eastern half is the Ladera Formation (Miocene age). On top of this bedrock at various places along the accelerator alignment is the Santa Clara Formation (Pleistocene age), where alluvial deposits of sand and gravel are found. At the surface is a soil overburden of non-consolidated earth material averaging from 0.1 to $1.5 \mathrm{~m}$ in depth. A more detailed description of the SLAC geology can be found in the SLAC Hydrogeologic Review Report (SLAC-I-750-2A15H-002).

\subsection{Local Climate}

The climate in the SLAC area is Mediterranean. Winters are cool and moist, and summers are mostly warm and dry. Long-term weather data describing conditions in the area have been assembled from official and unofficial weather records at Palo Alto Fire Station Number 3, which is 4.8 $\mathrm{km}$ east of SLAC. The SLAC site is 60 to $120 \mathrm{~m}$ higher than the Palo Alto Station and is free of the moderating influence of the city; temperatures therefore average about two degrees lower than those in Palo Alto. Daily mean temperatures are seldom below zero degrees Centigrade or above 30 degrees Centigrade.

Rainfall averages about 560 millimeters $(\mathrm{mm})$ per year. The distribution of precipitation is highly seasonal. About $75 \%$ of the precipitation, including most of the major storms, occurs during the four-month period from December through March. Most winter storm periods are from two days to a week in duration. The storm centers are usually characterized by relatively heavy rainfall and high winds. The combination of topography and air movement produces substantial fluctuations in intensity, which can best be characterized as a series of storm cells following one another so as to produce heavy precipitation for periods of five to fifteen minutes with lulls in between.

\subsection{Land U se}

San Mateo County has the ultimate planning responsibility with respect to University lands that are within the county, but not within an incorporated city. The San Mateo County General Plan is the primary land-use regulatory tool with respect to such lands. Adherence is made to all applicable federal, state, and local regulations, including chemical and sanitary discharges that might (directly or indirectly) adversely affect environmental quality.

The Board of Trustees of Stanford University is responsible for preserving and protecting Stanford's land endowment for the use of present and future generations of students and faculty. While financial and political influences on land-use policy are taken into account, the dominant and prevailing consideration is the appropriateness of those policies in the furtherance of the University's academic mission. Board policies are designed to encourage land uses consistent with the institutional characteristics and purposes of Stanford, and to discourage those uses or claims which do not relate to or support the mainstream activities of the University. SLAC falls into the former category.

The purpose of the Stanford land endowment is to provide adequate land for facilities and space for instructional and research activities of the University. The use of lands is planned in a manner consistent with the characteristics of Stanford as a residential teaching and research university, and provides flexibility for unanticipated changes in academic needs. Cooperation with adjoining communities is important and the concerns of neighboring jurisdictions are considered in the planning process. 


\subsection{Description of Program}

The SLAC program centers around experimental and theoretical research in elementary particle physics using accelerated electron beams and a broad program of research in atomic and solid-state physics, chemistry, and biology using synchrotron radiation from accelerated electron beams. There is also an active program in the development of accelerators, detectors, and new sources and instrumentation for synchrotron radiation research. Scientists from all parts of the United States and from throughout the world participate in the experimental programs at SLAC.

The main instrument of research is the 3.2-km linear accelerator (linac), which generates highintensity beams of electrons and positrons up to $50 \mathrm{GeV}$. These are among the highest-energy electron and positron beams available in the world. The linac is also used for injecting electrons and positrons into colliding-beam storage rings for particle physics research.

The Positron-Electron Project (PEP) storage ring is about 800 meters in diameter. While the original PEP program was completed in 1990, the storage ring has since been upgraded to serve as an Asymmetric $B$ Factory (known as PEP-II) to study the $B$ meson. PEP-II uses much of the existing PEP equipment and infrastructure and completed final commissioning with the BaBar detector in 1999.

A smaller storage ring, the Stanford Positron-Electron Asymmetric Ring (SPEAR), contains a separate, shorter linac and a booster ring for injecting accelerated beams of electrons. SPEAR is fully dedicated to synchrotron radiation research. The synchrotron light generated by the SPEAR storage ring is used by the Stanford Synchrotron Radiation Laboratory (SSRL) to perform experiments. SLAC is also host of the Next Linear Collider (NLC) test facilities, including the Final Focus Test Beam (FFTB), and the Next Linear Collider Test Accelerator (NLCTA).

\subsection{Site Water U sage}

SLAC domestic water is furnished via the Menlo Park Municipal Water Department (MPMWD), whose source is the City of San Francisco-operated Hetch Hetchy aqueduct system from reservoirs in the Sierra Nevada. SLAC and the neighboring Sharon Heights development, including the shopping center, receive water service from an independent system (called Zone 3) within the MPMWD.

This separate system taps the Hetch Hetchy aqueduct and pumps water up to a 7,600-cubic meter reservoir west of Sand Hill Road. The Zone 3 system was constructed in 1962 under special agreements between the City of Menlo Park, the developer of Sharon Heights, Stanford University, and the DOE. Since the cost of construction, including reservoir, pump station, and transmission lines, was shared among the various parties, each party has a vested interest in, and is entitled to, certain capacity rights in accordance with these agreements.

Drinking water and process water are supplied to SLAC by the City of Menlo Park from the Hetch Hetchy water system. Drinking water and process water are transported throughout the facility by a distribution system protected by backflow prevention devices. The backflow prevention devices are maintained by the Facilities Office. There are no drinking-water wells at SLAC. The nearest drinking-water well to SLAC is 1,500 feet from the SLAC border.

Use of water at SLAC is about equally divided between accelerator and equipment cooling, and domestic uses (such as landscape irrigation, sanitary sewer and drinking water). The average water consumption by SLAC for CY99 was 338,200 gallons per day. Since half of the water is necessary for machine cooling, the daily consumption of this component of water usage varies directly with the accelerator running schedule, and hence also varies directly with electric power demand (the domestic water usage is relatively constant and is insensitive to the accelerator schedule). 
The relationship between power and water consumption can be appreciated if one considers that $85 \%$ of the power used in linac operation is finally dissipated by water evaporation, in the ratio of about 630 kilowatt-hours (kWh) per cubic meter of water. SLAC now employs six cooling-water towers with a total cooling capacity of 79 megawatts (MW) to dissipate the heat generated by the linac and other experimental apparati.

Power-consuming devices are cooled directly by a recycling closed-loop system of low conductivity water (LCW). The LCW is piped from the accelerator (or other devices to be cooled) to the cooling towers, where heat is transferred from the closed system to the domestic water in the towers.

Prior to discharge, the LCW from the closed system is sampled and analyzed for radioactivity. A portion of the tower water is ultimately evaporated into the atmosphere. Because of this constant evaporation during operation, the remaining water gradually increases in mineral content, and eventually must be discarded as "blowdown" water. SLAC discharged a total of 14,139,102 gallons of wastewater to the sanitary sewer system in 1999, an average of 38,737 gallons per day.

\subsection{Demographics}

The populated area around SLAC is a mixture of offices, schools, single-family housing, apartments, condominiums, the university, and grazing lands. SLAC is surrounded mainly by five communities: Atherton town, West Menlo Park, Woodside town, Portola Valley town, and Stanford. Population and housing unit data from the most recent census (1990) of these five communities are shown in Table 1-1.

Table 1-1 Demographic Data

\begin{tabular}{|l|c|c|c|c|}
\hline Geographic Area & $\begin{array}{c}\text { Population } \\
\text { (persons) }\end{array}$ & $\begin{array}{c}\text { Pop. Density } \\
\text { (per sq mile) }\end{array}$ & $\begin{array}{c}\text { Housing } \\
\text { (units) }\end{array}$ & $\begin{array}{c}\text { Land Area } \\
\text { (sq mile) }\end{array}$ \\
\hline \hline Atherton town & 7,163 & $1,463.32$ & 2,518 & 4.895 \\
\hline West Menlo Park & 3,959 & $7,086.19$ & 1,701 & 0.559 \\
\hline Portola Valley town & 4,194 & 458.02 & 1,675 & 9.157 \\
\hline Woodside town & 5,035 & 428.88 & 1,892 & 11.740 \\
\hline Stanford & 18,097 & $6,569.14$ & 4,770 & 2.755 \\
\hline Total & 38,448 & NA & 12,556 & 29.105 \\
\hline
\end{tabular}

A population estimate within $80 \mathrm{~km}$ of SLAC was determined as part of the required input to the CAP88-PC computer code used to demonstrate compliance with the Clean Air Act (CAA). Population data from the 1990 census of San Mateo County and Santa Clara County were used in this study. The area was divided into 13 concentric circles and 16 compass sectors. The population distribution is summarized in Table 1-2 .

Table 1-2 Radial Population Data for CAP88-PC

\begin{tabular}{|c|c|c|c|c|c|c|c|c|c|c|c|c|c|}
\hline $\begin{array}{l}0.1 \\
\mathrm{~km}\end{array}$ & $\begin{array}{l}0.3 \\
\text { km }\end{array}$ & $\begin{array}{l}0.5 \\
\mathrm{~km}\end{array}$ & $\begin{array}{l}1.0 \\
\mathrm{~km}\end{array}$ & $\begin{array}{l}2.0 \\
\mathrm{~km}\end{array}$ & $\begin{array}{l}4.0 \\
\mathrm{~km}\end{array}$ & $\begin{array}{l}6.0 \\
\mathrm{~km}\end{array}$ & $\begin{array}{l}8.0 \\
\text { km }\end{array}$ & $\begin{array}{c}10.0 \\
\mathrm{~km}\end{array}$ & $\begin{array}{c}30.0 \\
\mathrm{~km}\end{array}$ & $\begin{array}{r}40.0 \\
\text { km }\end{array}$ & $\begin{array}{c}60.0 \\
\mathrm{~km}\end{array}$ & $\begin{array}{c}80.0 \\
\text { km }\end{array}$ & Total \\
\hline 0 & 0 & 1,214 & 2,825 & 14,106 & 31,679 & 42,832 & 131,629 & 114,377 & 665,574 & $1,232,353$ & $1,716,571$ & 964,283 & $4,917,443$ \\
\hline
\end{tabular}




\section{Protection of
Environment \\ Environmental Compliance}

\section{$2.1 \quad$ General}

This section of the 1999 Site Environmental Report provides an overview of the Environment, Safety, and Health (ES\&H) Division's organization and its responsibilities for environmental compliance. The ES\&H program is designed to ensure that the Stanford Linear Accelerator Center (SLAC) operates in a safe, environmentally responsible manner, and complies with all the applicable ES\&H laws, regulations, and standards. Further information about the ES\&H Division is available at:

http://www.slac.stanford.edu/esh/esh.html

\subsection{O rganizational O verview}

The ES\&H Division consists of five departments, a division office, and a Program Planning Office. Their shared goal is to help ensure that SLAC operates in compliance with federal, state, and local regulations, as well as Department of Energy (DOE) Orders related to environment, safety, and health. The five departments are:

- Environmental Protection and Restoration (EPR)

The EPR Department oversees the majority of the SLAC environmental programs, including environmental restoration, air quality, storm water and industrial wastewater, polychlorinated biphenyls and groundwater.

- Operational Health Physics (OHP)

The OHP Department oversees radiological monitoring and dosimetry at SLAC.

- Radiation Physics (RP)

The RP Department conducts beam checkouts of new experiments to ensure shielding adequacy for the protection of the workers and members of the general public.

- Safety, Health, and Assurance (SHA)

The SHA Department oversees audits for quality assurance for SLAC's environmental activities.

- Waste Management (WM)

The WM Department develops and implements waste minimization and pollution prevention plans and coordinates the disposal of regulated waste. 


\subsection{Compliance Program Summary}

\subsubsection{WSS Summary}

The laws and regulations that specify the environment, safety and health requirements for the laboratory have been identified and are contained in the SLAC Work Smart Standards (WSS) Set. This set of standards was incorporated into the SLAC Management and Operating contract and is reviewed annually.

The WSS Set requirements are based on potential hazards that have been identified by the people who work at SLAC. It is not necessary for every worker to know the details of these laws and regulations; staff in the ES\&H Division are available to assist, upon request. However, it is necessary that workers know about the hazards associated with their jobs and that managers and supervisors know how to get help with understanding the parts of the SLAC WSS Set that apply to them.

\subsubsection{Safety Management System Summary}

The DOE requires its contractors, including Stanford University for SLAC, to manage and perform work in accordance with a documented Safety Management System (SMS). This directive comes from DOE P 450.4, Safety Management System Policy, which commits the DOE to institutionalizing an integrated SMS throughout the DOE complex. The requirement is implemented through the incorporation of a contract clause from the DOE Acquisition Regulations (DEAR) 970.5204-2, "Integration of Environment Safety, and Health Into Planning and Execution." This clause was incorporated into the contract between DOE and Stanford University for operation of SLAC on February 5, 1998.

The contract between Stanford University and the DOE for the operation of SLAC states, in part:

The Contractor [SLAC] will perform work safely in a manner that ensures adequate protection for employees, the public, and the environment and shall be accountable for the safe performance of work. The Contractor shall exercise a degree of care commensurate with the work and the associated hazards. The Contractor shall ensure that management of environment, safety, and health (ES\&H) functions and activities becomes an integral but visible part of the Contractor's work planning and execution processes.

SLAC's commitment to integrating ES\&H considerations into its mission preceded the establishment of the DOE SMS requirements. This is evident in the strong ES\&H Program developed by SLAC long before the SMS clause was incorporated into the operating contract.

The SLAC Safety Management System document, (SLAC-I-720-0A008-001), describes the SLAC SMS program and how SLAC integrates safety and environmental protection into management and work practices at all levels so that its mission is accomplished while protecting the worker, the public, and the environment. 


\subsubsection{Environmental Permits and N otifications Summary}

The general permits held by SLAC in calendar year 1999 (CY99) are shown in Table 2-1.

The specific permits held by SLAC in CY99 are shown in Table 2-2.

Table 2-1 G eneral Permits and N otifications

\begin{tabular}{|c|l|}
\hline Quantity & \multicolumn{1}{c|}{ Name } \\
\hline \hline 20 & $\begin{array}{l}\text { Sources listed on the Bay Area Air Quality Management District (BAAQMD) } \\
\text { Permit-to-Operate (13 Permitted Sources - 7 Exempt Sources) } \\
\text { For more information, see Table 3-1. }\end{array}$ \\
\hline 4 & $\begin{array}{l}\text { Notifications to USEPA for halogenated solvent cleaning units are under the } \\
\text { National Emission Standards for Hazardous Air Pollutants (NESHAPs Program). } \\
\text { Two of these sources had been permitted by the BAAQMD at year-end, and two } \\
\text { were pending. }\end{array}$ \\
\hline 2 & Tiered Permits for Fixed Treatment Units (Permit-By-Rule [PBR] Permit) \\
\hline 1 & Tiered Permit for Fixed Treatment Units (Conditional Authorization Permit) \\
\hline 1 & Industrial Activities Storm Water General Permit \\
\hline 1 & $\begin{array}{l}\text { Hazardous Waste Generator Environmental Protection Agency (EPA) ID No. } \\
\text { CA8890016126 }\end{array}$ \\
\hline
\end{tabular}

Table 2-2 Specific Permits

\begin{tabular}{|c|c|c|c|}
\hline Permit From & Permit Type & Permit N umber & Expiration D ate \\
\hline BAAQMD & Permit-to-Operate & Plant No. 556, 20 listed sources & July 1, 1999 \\
\hline \multirow[t]{3}{*}{$\begin{array}{l}\text { Department of Toxic } \\
\text { Substances Control (TSCA) }\end{array}$} & \multirow[t]{3}{*}{$\begin{array}{l}\text { Tiered Permit for fixed } \\
\text { treatment units }\end{array}$} & $\begin{array}{l}\text { Unit } 1 \text {-Building } 038, \text { PBR } \\
\text { Permit for Rinse Water Treat- } \\
\text { ment Plant (RWTP) }\end{array}$ & March 30, 2000 \\
\hline & & $\begin{array}{l}\text { Unit 2-Building 038, Sludge } \\
\text { Dryer (PBR) }\end{array}$ & March 30, 2000 \\
\hline & & $\begin{array}{l}\text { Unit } 3 \text {-Building } 460 \text {, } \\
\text { Conditional Authorization Per- } \\
\text { mit for Batch Treatment Plant } \\
(\mathrm{BTP})^{\mathrm{a}}\end{array}$ & March 30, 2000 \\
\hline \multirow[t]{3}{*}{$\begin{array}{l}\text { West Bay Sanitary District } \\
\text { and South Bayside System } \\
\text { Authority }\end{array}$} & \multirow[t]{3}{*}{ Wastewater Discharge } & $\begin{array}{l}\text { Permit No. WB970401-F } \\
\text { (Flow Meter Station at Sand } \\
\text { Hill Road) }\end{array}$ & March 31, 2002 \\
\hline & & $\begin{array}{l}\text { Permit No. WB970401-P } \\
\text { (Rinsewater Treatment Plant) }\end{array}$ & March 31, 2002 \\
\hline & & $\begin{array}{l}\text { Permit No. WB970401-HX } \\
\text { (Batch Treatment Plant) }\end{array}$ & March 31, 2002 \\
\hline $\begin{array}{l}\text { San Francisco Bay Regional } \\
\text { Water Quality Control Board } \\
\text { (RWQCB) }\end{array}$ & $\begin{array}{l}\text { Industrial Activities } \\
\text { Storm Water General } \\
\text { Permit }\end{array}$ & Permit No. CAS000001 & July 1,2002 \\
\hline
\end{tabular}

1 In the Tiered Permits, this plant is referred to as a facility. 


\subsubsection{Assessments, Inspections, and Q uality Assurance Summaries}

\subsubsection{Assessments}

Quarterly conduct-of-operations audits of the Environmental Radiological Program were performed by DOE. The California Department of Health Services, Radiation Health Branch conducts an ongoing site-boundary radiation monitoring program. There were four thermoluminescent dosimeter changeouts in 1999.

\subsubsection{Self-Assessment Program}

An annual system of site-wide Safety and Environmental (S\&E) Discussions is used at SLAC to identify and correct ES\&H deficiencies. This program provides the opportunity for all laboratory employees, in small discussion groups, to reflect on the most important ES\&H issues and suggest solutions. Divisions may take action on this information directly, or they may develop site-wide corrective action plans. No serious environmental issues were identified in CY99.

In 1999, laboratory staff were provided information (through memos, briefings, internal publications, and a S\&E web site) to ensure they were aware of detailed suggestions for environmental issues in their work areas.

\subsubsection{Inspections}

A summary of the enforcement inspections for CY99 is shown in Table 2-3

Table 2-3 Enforcement Inspections

\begin{tabular}{|l|l|l|l|}
\hline Inspection Date & \multicolumn{1}{|c|}{ Inspection Type } & Inspection Agency & \multicolumn{1}{c|}{ Findings/Results } \\
\hline \hline June 3, 1999 & $\begin{array}{l}\text { Annual Air } \\
\text { Inspection }\end{array}$ & BAAQMD & $\begin{array}{l}\text { Satisfactory. } \\
\text { For details, see 3.2.2 }\end{array}$ \\
\hline $\begin{array}{l}\text { March-September, } \\
1999\end{array}$ & $\begin{array}{l}\text { Hazardous Waste } \\
\text { Generator }\end{array}$ & San Mateo County & $\begin{array}{l}\text { Findings of non-compliance. } \\
\text { Corrective actions initiated. For } \\
\text { details, see 3.5.2 }\end{array}$ \\
\hline December 1999 & $\begin{array}{l}\text { Tiered Permit for } \\
\text { fixed treatment units }\end{array}$ & San Mateo County & No findings. \\
\hline
\end{tabular}

\subsubsection{Quality Assurance}

The SLAC site-wide Quality Assurance (QA) Program has been influenced by the requirements of DOE Order 5700.6C. The QA Program is described in the SLAC Institutional Quality Assurance Program Plan (SLAC-I-7700A17M-001). This document was approved by the DOE in May 1993. The plan defines the roles, responsibilities, and authorities for implementation of the ten criteria from DOE Order 414.1, which replaced DOE Order 5700.6C in CY99. 
The SHA Department is responsible for:

- $\quad$ Auditing the line QA as well as environment, safety, and health $(\mathrm{ES} \& \mathrm{H})$ programs.

- Maintaining the SLAC Institutional Quality Assurance Program Plan.

- $\quad$ Providing direction for implementation of the ten criteria from DOE Order 5700.6C.

\section{Independent Assessment Program}

A major multi-year program of ES\&H assessments is currently in place at the laboratory. This assessment is conducted twice a year by the consulting firm of Dames and Moore. The assessment personnel are highly qualified ES\&H professionals. The Dames and Moore assessment activities covered the following topics in 1999:

- $\quad$ Electrical Safety

- Fire Protection

- General Health and Safety

- Hoisting and Rigging

- Medical Services

- Non-ionizing Radiation

\section{Radioanalysis Laboratory}

In CY99, SLAC participated in one external blind sample quality assessment program, the DOE Quality Assessment Program (QAP), run by the Environmental Measurements Laboratory (EML).

Participation in the QAP consisted of analyzing water samples provided by EML for tritium and gamma-emitting radionuclides and reporting the results to EML. There were two QAP evaluations in CY99, one in March and one in September.

The gamma-emitting radionuclides detected in the QAP samples that are found at SLAC are: Cobalt-60 $\left({ }^{60} \mathrm{Co}\right)$ and Cesium-137 $\left({ }^{137} \mathrm{Cs}\right)$. SLAC's performance in these evaluations was acceptable.

\section{Environmental Monitoring}

Table 2-4 lists the procedures and policies used to support the QA Program for environmental monitoring activities.

Table 2-4 Q A Program D ocuments

\begin{tabular}{|l|l|}
\hline \multicolumn{1}{|c|}{ Document \# } & \multicolumn{1}{|c|}{ Title } \\
\hline \hline QC-030-004-00-R0 & Radioactive Water Sampling/Analysis Audit Procedure \\
\hline SLAC-I-770-0A19C-001 & Oversight Procedure \\
\hline SLAC-I-770-2A19C-004 & Non-Radiological Sampling Audit Procedure \\
\hline SLAC-I-770-0A16Z-001 & Establishing Data Quality Objectives \\
\hline
\end{tabular}




\section{Environmental Restoration Program}

The Environmental Restoration Program uses the Quality Assurance Project Plan for the Remedial Investigation and Feasibility Study for soil and groundwater contamination investigations. This document has most of the components required of Quality Assurance Project Plans according to EPA, the Comprehensive Environmental Response, Compensation, and Liability Act (CERCLA, or Superfund), and DOE guidance documents. These components include defining required laboratory and field QA/QC procedures and corrective actions, as well as data validation and reporting.

\subsubsection{Environmental Incidents/Releases Summary}

Table 2-5 summarizes incidents and releases which exceeded regulatory permit limits or local, state, or federal reporting requirements.

Note: The releases shown in Table 2-5 were unauthorized non-stormwater discharges under the General Industrial Stormwater Permit.

Table 2-5 Environmental Incidents/ Releases Summary

\begin{tabular}{|l|c|l|l|l|l|}
\hline Date & Material & \multicolumn{1}{|c|}{ Amount } & Location & \multicolumn{1}{|c|}{ Description } & \multicolumn{1}{|c|}{$\begin{array}{l}\text { Corrective Action } \\
\text { Taken/To Be Taken }\end{array}$} \\
\hline \hline $5 / 11 / 99$ & Sewage & 900 gallons & IR-12 & Sanitary sewer overflow. & Roots removed. \\
\hline $6 / 8 / 99$ & Sewage & 1200 gallons & IR-12 & Sanitary sewer overflow. & Sewer lines cleaned. \\
\hline $6 / 14 / 99$ & LCW $^{1}$ & 2,500 gallons & IR-6 & Failed line connection. & Repaired connection. \\
\hline $12 / 16 / 99$ & LCW & 70,000 gallons & SSRL & $\begin{array}{l}\text { Release of water due to } \\
\text { spontaneous pipe failure } \\
\text { (aging infrastructure). }\end{array}$ & $\begin{array}{l}\text { Repaired connection. } \\
\text { Reviewed status with } \\
\text { operations. }\end{array}$ \\
\hline
\end{tabular}

1 LCW = Low conductivity water.

\subsubsection{Radiological}

There were no reportable quantity releases of radioactive material to the environment exceeding limits in CY99.

\subsubsection{Non-Radiological}

No wastewater discharge permit violations occurred during CY99. Four accidental releases entered the storm drain system. The RWQCB was notified as appropriate. The materials released included untreated sewage and domestic water.

All four releases were determined to represent minimal or negligible risk. To identify corrective actions for the site-wide sanitary sewer system, an assessment was completed in CY99. Funding has been requested to repair the highest priority areas. 


\subsubsection{Program Compliance Summary}

Table 2-7 lists the major statutes, executive orders, and main documents that govern the activities at SLAC. It also indicates the location of the data in this document, along with any pertinent comments.

\section{$2.4 \quad$ Training}

In CY99, personnel who handle hazardous chemicals and waste received instruction in chemical and waste management, waste minimization, pollution prevention, stormwater protection, on-site transportation of hazardous chemicals and waste, and spill and emergency response. The classroom instruction provided was intended to increase awareness in the aforementioned areas and to ensure environmental compliance.

\subsection{Environmental Performance Measures}

SLAC evaluates its performance against performance measures. The performance measures include:

- Environmental Violations and Releases

- Environmental Restoration Goals

- Waste Minimization/Pollution Prevention Goals

- Hazardous and Radioactive Waste

\subsubsection{Specific Measures}

The specific performance measures can be found at:

http://www.slac.stanford.edu/esh/perfmeas/perfmeas.html

\subsubsection{Results}

The performance measure results for CY99, as found in the Stanford Linear Accelerator Center Environment, Safety, and Health Third Quarter Report (July 1-September 30, 1999) are shown in Table 2-6.

Table 2-6 CY99 Performance Measure Results

\begin{tabular}{|c|c|}
\hline Performance Measure & Results \\
\hline \hline Environmental Violations and Releases & Far Exceeds Expectations \\
\hline Environmental Restoration Goals & Exceeds Expectations \\
\hline Hazardous and Radioactive Waste & Far Exceeds Expectations \\
\hline Waste Minimization/Pollution Prevention Goals & Far Exceeds Expectations \\
\hline
\end{tabular}


Table 2-7 Compliance Summary

\begin{tabular}{|c|c|c|c|c|}
\hline Major Statute/ Executive Order & Governing Document & Status & ASER Location & Comments \\
\hline $\begin{array}{l}\text { Superfund Amendments and Reautho- } \\
\text { rization Act } \\
\text { (SARA)/ EPCRA } \\
42 \text { USC, Section11022 (Tier II) }\end{array}$ & $\begin{array}{l}\text { San Mateo County } \\
\text { Ordinance } \\
\text { California Health and Safety } \\
\text { (CHS), Chapter 6.95; Article } \\
\text { 80, Uniform Fire Code }\end{array}$ & $\begin{array}{l}\text { Meets } \\
\text { Requirements }\end{array}$ & Section 3.6 .1 & $\begin{array}{l}\text { The Hazardous Materials Business } \\
\text { Plan and Hazardous Material } \\
\text { Annual } \\
\text { Inventory }\end{array}$ \\
\hline $\begin{array}{l}\text { Executive Order (EO) \#12843/ Emer- } \\
\text { gency Planning and Community Right- } \\
\text { to-Know Act (EPCRA) }\end{array}$ & 40CFR372 & $\begin{array}{l}\text { Meets } \\
\text { Requirements }\end{array}$ & Section 3.6.1 & Toxic Release Inventory \\
\hline $\begin{array}{l}\text { Resource Conservation and Recovery } \\
\text { Act (RCRA) 40CFR261 and } \\
\text { following sections. }\end{array}$ & $\begin{array}{l}\text { Title } 22 \text { California Code of } \\
\text { Regulations }\end{array}$ & $\begin{array}{l}\text { Corrective } \\
\text { Actions Initiated }\end{array}$ & Section 3.5 .1 & $\begin{array}{l}\text { Hazardous Waste Generator } \\
\text { requirements }\end{array}$ \\
\hline $\begin{array}{l}\text { National Environmental Policy Act } \\
\text { (NEPA) }\end{array}$ & $\begin{array}{l}\text { NEPA- } 42 \text { USC } 4321-4347,(40 \\
\text { CFR parts } 1500-1508)\end{array}$ & $\begin{array}{l}\text { Meets } \\
\text { Requirements }\end{array}$ & Section 3.8 .1 & \\
\hline $\begin{array}{l}\text { Clean Air Act } \\
\text { 40CFR63 } \\
\text { 40CFR82 }\end{array}$ & $\begin{array}{l}\text { BAAQMD } \\
\text { Rules and Regulations }\end{array}$ & $\begin{array}{l}\text { Meets } \\
\text { Requirements }\end{array}$ & $\begin{array}{l}\text { Section 3.2.1- Regulatory } \\
\text { Framework }\end{array}$ & $\begin{array}{l}\text { SLAC has both a Rad and non-Rad } \\
\text { Air quality protection program. }\end{array}$ \\
\hline Clean Water Act- Groundwater & $\begin{array}{l}\text { Federal Water Pollution Con- } \\
\text { trol Act (Clean Water Act) - } 33 \\
\text { USC } 1344 \\
\text { ( } 40 \text { CFR Section } 400 \text { et seq.) }\end{array}$ & $\begin{array}{l}\text { Meets } \\
\text { Requirements }\end{array}$ & Section 3.3 .1 & $\begin{array}{l}\text { New wells were installed in CY99 } \\
\text { to evaluate specific locations for } \\
\text { potential contaminants near SLAC } \\
\text { facilities. }\end{array}$ \\
\hline Clean Water Act- Surface Water & $\begin{array}{l}\text { Stormwater Pollution } \\
\text { Prevention Plan (SWPPP) }\end{array}$ & $\begin{array}{l}\text { Meets } \\
\text { Requirements }\end{array}$ & Section 3.2.1- Surface Water & $\begin{array}{l}\text { SLAC is in the process of eliminat- } \\
\text { ing identified illicit connections } \\
\text { consisting primarily of infiltrating } \\
\text { groundwater into below-grade } \\
\text { structures. This is a multi-year pro- } \\
\text { gram. }\end{array}$ \\
\hline $\begin{array}{l}\text { Clean Water Act- } \\
\text { Industrial Wastewater }\end{array}$ & $\begin{array}{l}\text { Permit No. WB970401-F } \\
\text { Permit No. WB970401-P } \\
\text { Permit No. WB970401-HX }\end{array}$ & $\begin{array}{l}\text { Meets } \\
\text { Requirements }\end{array}$ & $\begin{array}{l}\text { Section 3.3.4 - Industrial and } \\
\text { Sanitary Wastewater }\end{array}$ & $\begin{array}{l}\text { SLAC was in compliance with all } \\
\text { specified permit limits. }\end{array}$ \\
\hline
\end{tabular}


Table 2-7 Compliance Summary (continued)

\begin{tabular}{|c|c|c|c|c|}
\hline Major Statute/ Executive Order & Governing Document & Stahus & ASER Location & Comments \\
\hline Safe Drinking Water Act (SDWA) & & $\begin{array}{l}\text { Meets } \\
\text { Requirements }\end{array}$ & Section 3.3 .1 & $\begin{array}{l}\text { The Facilities Department main- } \\
\text { tains a backflow prevention program } \\
\text { to protect all drinking and process } \\
\text { water distribution systems. }\end{array}$ \\
\hline Toxic Substances Control Act (TSCA) & 40CFR761 & $\begin{array}{l}\text { Meets } \\
\text { Requirements }\end{array}$ & Section 3.7 .1 & \\
\hline $\begin{array}{l}\text { Federal Insecticide, Fungicide, and } \\
\text { Rodenticide Act (FIFRA) }\end{array}$ & $\begin{array}{l}7 \text { USC Section 136, and } \\
\text { following sections }\end{array}$ & $\begin{array}{l}\text { Meets } \\
\text { Requirements }\end{array}$ & Section 3.3 .6 & $\begin{array}{l}\text { SLAC uses licensed subcontractors } \\
\text { to apply registered pesticides. Proce- } \\
\text { dures were developed in CY94 that } \\
\text { are incorporated into the subcon- } \\
\text { tracts for landscape maintenance and } \\
\text { pest control. SLAC personnel apply } \\
\text { general-use pesticides only. }\end{array}$ \\
\hline $\begin{array}{l}\text { Endangered Species Act (ESA) } \\
16 \text { USC, } 1531 \text { and following sections }\end{array}$ & $\begin{array}{l}\text { Pre-Construction Notice, US } \\
\text { Army Corps of Engineers }\end{array}$ & $\begin{array}{l}\text { Meets } \\
\text { Requirements }\end{array}$ & Section 3.3 .5 & $\begin{array}{l}\text { California red-legged frog desig- } \\
\text { nated as threatened by the federal } \\
\text { government. }\end{array}$ \\
\hline $\begin{array}{l}\text { National Historic Preservation Act } \\
\text { (NHPA) }\end{array}$ & NHPA 16 USC 470f & $\begin{array}{l}\text { Meets } \\
\text { Requirements }\end{array}$ & Not Applicable & No eligible NHPA sites at SLAC. \\
\hline $\begin{array}{l}\text { Executive Order 11988, } \\
\text { Floodplain Management }\end{array}$ & $\begin{array}{l}\text { Executive Order 11988- } \\
\text { Floodplain Management (10 } \\
\text { CFR Part } 1022\end{array}$ & $\begin{array}{l}\text { Meets } \\
\text { Requirements }\end{array}$ & Section 3.3 .7 & $\begin{array}{l}\text { According to the Federal Emergency } \\
\text { Management Agency (FEMA), a } \\
\text { one-percent flood event would not } \\
\text { reach the SLAC facility, but would } \\
\text { be confined to San Francisquito } \\
\text { Creek. }\end{array}$ \\
\hline $\begin{array}{l}\text { Executive Order 11990, Protection of } \\
\text { Wetlands }\end{array}$ & $\begin{array}{l}\text { Executive Order 11990- } \\
\text { Protection of wetlands }\end{array}$ & $\begin{array}{l}\text { Meets } \\
\text { Requirements }\end{array}$ & Section 3.3 .6 & $\begin{array}{l}\text { Jurisdictional wetlands represent } \\
\text { less than one acre of the } 426 \text {-acre } \\
\text { SLAC leaseholding. }\end{array}$ \\
\hline $\begin{array}{l}\text { Tank Management } \\
\text { Above-ground Petroleum Storage Act }\end{array}$ & CHS Code, Section 25270 & $\begin{array}{l}\text { Meets } \\
\text { Requirements }\end{array}$ & Section 3.7 .2 & $\begin{array}{l}\text { Next biennial report and fees to } \\
\text { State are due on } 7 / 1 / 2000 \text {. }\end{array}$ \\
\hline
\end{tabular}




\section{$x_{2}$ \\ Environmental Non-Radiological Program}

\subsection{General}

This section provides an overview of environmental activities that are performed at the Stanford Linear Accelerator Center (SLAC). Such activities are designed to comply with laws and regulations, to enhance environmental quality, and to improve understanding of the effects of potential environmental pollutants from site operations.

\subsection{Air Programs}

\subsubsection{Regulatory Framework}

In the San Francisco Bay Area, most federal and state air regulatory programs are implemented through the rules and regulations of the Bay Area Air Quality Management District (BAAQMD). Included in BAAQMD's roles and responsibilities are implementation of Title V of the Clean Air Act (CAA). The primary mechanisms by which BAAQMD regulates SLAC air emissions include:

- New source permit evaluations.

- Annual information updates for existing permitted sources.

- Annual information updates for emissions of air toxics as identified by the California Air Resources Board in its Toxic Substances Check List.

- Annual enforcement inspections.

On October 20, 1999, BAAQMD adopted significant revisions to Regulation 2, Permits, Rule 6, Major Facility Review. This is the regulation by which BAAQMD implements Title V of the Clean Air Act. The net impact of these revisions was that SLAC became subject to BAAQMD's Title $\mathrm{V}$ permitting program and is required to take one of the following three actions by October 20, 2000:

- Apply for a Major Facility Review Permit

- Demonstrate that its "potential to emit" is below the major facility thresholds defined in BAAQMD Regulation 2-6-312

- Apply for and receive a Synthetic Minor Operating Permit (SMOP). 
SLAC is also subject to air quality regulatory programs that are administered by agencies other than the BAAQMD. These programs include the following.

- The National Emission Standards for Halogenated Solvent Cleaning, under Title 40 Code of Federal Regulations,(40CFR), Part 63.460 (40CFR63.460), which is administered through the Air Division of Region 9 of the Environmental Protection Agency (EPA)

- The Protection of Stratospheric Ozone requirements (40CFR82), also administered through the Air Division of EPA, Region 9

- The Toxic Chemical Release Reporting: Community Right-to-Know requirements (40CFR312). SLAC provides the appropriate information to meet these program requirements to Department of Energy at Oakland (DOE/OAK), which in turn provides the information from all DOE facilities under its jurisdiction to the EPA

- The California Accidental Release Program (CalARP), which combines the requirements of Section 112(r) of the CAA with California-specific requirements, and is administered through the San Mateo County Department of Health Services (SMC/ DHS)

\subsubsection{BAAQ MD-Implemented Programs}

\subsubsection{Source Permitting}

At the beginning of CY99, SLAC had one pending permit application with $\mathrm{BAAQMD}$, for the BaBar particle detector that is part of the new Asymmetric $\mathrm{B}$ Factory project. BAAQMD agreed with SLAC's position that two gas systems within the BaBar detector should be separately permitted, and on April 15 granted SLAC permits to operate the following:

- Source S-55, Drift Chamber System/BaBar Detector

- Source S-56, Resistive Plate Chamber System/BaBar Detector.

Permit Condition 16324.1 specified that total Precursor Organic Compound (POC) emissions from the two sources shall not exceed 2600 pounds in any consecutive 12-month period. This condition specifically caps the emissions of isobutane from the two gas systems.

As SLAC gained operating experience with the BaBar gas systems during CY99, it became apparent that emissions would be somewhat larger than were described in SLAC's original permit application. Discussions with BAAQMD clarified that increases of isobutane emissions beyond the range estimated in SLAC's original application would be acceptable as long as emissions stayed below the 2600 pound per 12 month criteria set forth in Permit Condition 16324.1. Other discussions clarified that emissions of $\mathrm{H}-$ 134a, a component of the Resistive Plate Chamber System gas mixture, were not subject to either Permit Condition 16324.1 or BAAQMD's general 15 pound per day organic gas emissions limitation, because $\mathrm{H}-134 \mathrm{a}$ is not classified by BAAQMD as a POC.

On January 11, 1999, SLAC submitted a permit application package for a new sludge dryer, abated by a wet scrubber. SLAC received an Authority to Construct the sludge dryer and scrubber on April 20, and following successful completion of a source test upon start-up, a Permit to Operate the sludge dryer and scrubber was received on October 28. 
Following completion of the permit process for the BaBar detector and the sludge dryer, SLAC had a total of 20 "current" sources listed in its facilitywide Permit to Operate, including 13 permitted and 7 exempt sources. Information regarding these sources is presented in Table 3-1.

Table 3-1 BAAQMD Permitted/Exempt Sources

\begin{tabular}{|c|c|c|c|}
\hline Source N umber & Source D escription & Permitted/Exempt & Emitted Chemicals/Materials ${ }^{\mathrm{a}}$ \\
\hline$\overline{\mathrm{S}-4}$ & Batch Vapor Degreaser & Permitted & Trichloroethane (TCA) \\
\hline S-5 & Paint Spray Booth & Permitted & Paints, Solvents \\
\hline S-11 & Metal Cutting Operations & Exempt & - \\
\hline S-17 & Metal Grinding Operations & Exempt & - \\
\hline $\mathrm{S}-21$ & $\begin{array}{l}\text { Anodizing, Pickling, \& Bright } \\
\text { Dip Operations }\end{array}$ & Permitted & Sulfuric Acid \\
\hline S-26 & Batch Solvent Cold Cleaner & Permitted & De-Greeze 500 \\
\hline S-34 & Batch Solvent Cold Cleaner & Permitted & De-Greeze 500 \\
\hline S-36 & Wipe Cleaning Operations & Permitted & $\begin{array}{l}\text { Isopropyl Alcohol, Acetone, } \\
\text { Methanol, TCA, other solvents }\end{array}$ \\
\hline S-37 & Batch Solvent Cold Cleaner & Permitted & Isopropyl Alcohol \\
\hline S-42 & Diesel Fuel Storage Tank & Exempt & - \\
\hline S-43 & Diesel Fuel Storage Tank & Exempt & - \\
\hline S-44 & Diesel Fuel Storage Tank & Exempt & - \\
\hline S-45 & Diesel Fuel Storage Tank & Exempt & - \\
\hline S-49 & Cyanide Room Scrubber & Exempt & - \\
\hline S-52 & Horizontal Firetube Boiler & Permitted & $\mathrm{NOx}, \mathrm{CO}_{2}, \mathrm{CO}$ \\
\hline S-53 & Horizontal Firetube Boiler & Permitted & $\mathrm{NOx}, \mathrm{CO}_{2}, \mathrm{CO}$ \\
\hline S-54 & $\begin{array}{l}\text { Near Zero Emissions (NZE) } \\
\text { Closed Loop Vapor } \\
\text { Degreaser }\end{array}$ & Permitted & Perchloroethylene \\
\hline S-55 & $\begin{array}{l}\text { Drift Chamber/BaBar Detec- } \\
\text { tor }\end{array}$ & Permitted & Isobutane \\
\hline S-56 & $\begin{array}{l}\text { Resistive Plate Chambers } \\
\text { BaBar Detector }\end{array}$ & Permitted & Isobutane, $\mathrm{H}-134 \mathrm{a}$ \\
\hline S-57 & Sludge Dryer & Permitted & $\mathrm{Cr}^{+6}, \mathrm{Cu}, \mathrm{Ni}$, other metals \\
\hline
\end{tabular}

a Emitted chemicals/materials not listed for exempt sources.

On June 18, SLAC submitted an information package to BAAQMD regarding its Lower Salvage Yard soil remediation project, designed to remove soil contaminated with polychlorinated biphenyls (PCBs) and volatile organic compounds (VOCs) from the Lower Salvage Yard. On June 23, BAAQMD notified SLAC that it agreed with SLAC's conclusion that the project was exempt from BAAQMD permitting requirements. 
During December 1999, SLAC submitted five source applications to BAAQMD. These application were pending at year-end. It was anticipated that of these five applications, four would likely result in SLAC being granted Permits to Operate the subject equipment, and the fifth would likely result in a determination that the source was exempt from permitting requirements. There was also the potential that BAAQMD would assess retroactive permitting fees and/or penalties, as all of the sources had been operated prior to submittal of the permit applications.

Ten other source evaluations were completed during 1999 which resulted in SLAC determining that the subject sources were exempt from BAAQMD permitting requirements. Completion of these evaluations meant that all "priority sources" (sources categorized as "new source evaluations" or "major historical source evaluations") had been completed. However, at year-end numerous "non-priority" air emissions sources remained backlogged.

\subsubsection{Annual U pdate/Air Toxics Reporting}

SLAC submitted its Annual Update to BAAQMD on April 14. As part of its submittal, SLAC informed BAAQMD that it intended to perform an "air emissions baseline inventory" (see Section 3.3.2.4) that would enable SLAC to develop better assess its reporting obligations vis-à-vis the Toxic Substances Check List information request distributed with BAAQMD's Annual Update Request. SLAC envisions revisiting its reporting obligations, if any, under the Toxic Substances Check List reporting program beginning in CY00, following the completion of the baseline inventory.

\subsubsection{Annual Facility Inspection}

On June 3, BAAQMD conducted its annual inspection of SLAC's facilities. No violations were noted at the time of the inspection, although the inspector requested that SLAC submit follow-up information regarding Sources S-5 (Paint Booth), S-52 and S-53 (Main Boilers), and S-56 (Resistive Plate Chambers/BaBar Detector). A copy of BAAQMD's inspection report was received on November 19, which formally documented that no Notices of Violation (NOVs) or Notices to Comply (NTCs) would be forthcoming as a result of the 1999 inspection.

\subsubsection{Baseline Air Emissions Inventory/Title V Permitting}

In order to determine its compliance obligations under BAAQMD's revised Title V permitting regulations, SLAC conducted Phase 1 of a baseline air emissions inventory project in CY99.

The scope of Phase 1 included all the currently permitted air emission sources at SLAC, as well as three major manufacturing/assembly areas (Buildings 25, 26, and 31) and historical large-scale physics particle detectors (SLD, Mark II). Phase 1 was completed in September.

The Phase 1 results indicated that SLAC's "potential to emit" approached the Title V permitting thresholds for individual Hazardous Air Pollutants (HAPs). 
While all the air emissions sources believed to be "major" sources of emissions were included in the scope of Phase 1, the major sources represent less than half of the total number of emission sources. Therefore, a decision was made that it would be prudent to conduct a second phase of the baseline inventory, in order to include many of the "minor" sources of air emissions at SLAC and thus more fully evaluate SLAC's Title V compliance obligations.

Phase 2 of the baseline inventory was to be conducted during the first quarter of 2000, with SLAC's decision as to which of the three required permitting actions to take (see Section 3.2.1) shortly thereafter. It is important to note that SLAC's actual emissions appear to be far below all Title V thresholds; however, the determination of whether a facility is "in" or "out" of the Title V permitting program rests on its "potential to emit", not its actual emissions.

An outgrowth of the Phase 1 baseline air emissions inventory and other Title V program development activities was an increasing awareness that SLAC's existing chemical information management systems would be inadequate to support the recordkeeping requirements of a Title V permit. Thus, in December 1999 the ESH Associate Director convened a 15-member "Chemical Use Tracking Work Group" to make recommendations regarding development of a computer-based information system necessary to support a Title $\mathrm{V}$ permit. The work group is scheduled to complete its activities in April 2000.

\subsubsection{U SEPA-Implemented Programs}

During CY99, SLAC identified two additional processes as being subject to the National Emissions Standards for Halogenated Solvent Cleaning, bringing the total number of site processes regulated under the program to four. An initial notification letter for the first additional process (Building 025 Plating Shop Tank 68) was submitted to EPA on December 2; the initial notification letter for the second process (Accelerator Department TCE cleaning process, Building 006) was submitted to EPA on January 31, 2000.

The two existing site processes regulated under the program were Source S-4, the Plating Shop's TCA degreaser, and Source S-54, the Plating Shop's NZE degreaser. These two degreasers were operated in compliance with the emissions limitations promulgated under the "Alternative Standards" portion of the Halogenated Solvent Cleaning standards at all times during CY99.

A meeting was held on August 6 with EPA representatives to discuss application of the Alternative Standards and Test Methods regulations to Source S-54. Source S-54 is a relatively unique piece of equipment and does not fit neatly into the operating procedures prescribed in the Test Methods portion of the regulations. Issue resolution is expected to occur in CY00.

No releases of stratospheric ozone depleting substances (ODSs) were reported during CY99 that were sufficiently large to be subject to the release reporting and corrective action requirements in the ODS regulations. In order to comply with a DOE directive and to improve the status of SLAC's ODS programs, it is anticipated that SLAC's existing ODS inventory will be upgraded during CY00 or CY01. 
SLAC is required by Executive Order 12856 to comply with "Right-to-Know" laws and pollution prevention requirements. One "Right-to-Know" regulatory program is incorporated into SLAC's air quality program, the Toxic Chemical Release Reporting: Community Right to Know program (more commonly known as the Toxics Release Inventory, or TRI, program). Based on available information such as Stores distribution records, Purchase Requisitions, and recordkeeping performed by certain chemical users, it did not appear that SLAC "otherwise used" any TRI-listed chemical above its threshold quantity during CY99.

However, it did appear that SLAC approached the threshold quantities for, at minimum, the following chemicals: nitric acid; 1,1,1-trichloroethane (TCA); and tetrachloroethylene (also known as perchloroethylene, or PERC). SLAC anticipates that the information system to be recommended by its "Chemical Use Tracking Work Group" in CY00 will significantly increase the degree of certainty that SLAC has that it is under the TRI threshold quantities.

\subsubsection{San Mateo County-Implemented Programs}

SLAC submitted its CalARP registration information to the San Mateo County Department of Health Services (the County) on 3/3/98. The original registration information was subsequently amended on 5/15/98. The net result of SLAC's submittals is that SLAC is currently registered under the CalARP program for the "Table 3" substances nitric acid and potassium cyanide.

Information received from the California Office of Emergency Services during CY99 appears to indicate that SLAC has an excellent case for "de-registering" its use of nitric acid. Additionally, a case can potentially be made for de-registering potassium cyanide based on the way SLAC actually manages and processes the chemical.

If SLAC's CalARP registration status is not changed (for example, SLAC is unable to deregister its use of nitric acid and potassium cyanide), then SLAC will be subject to CalARP program regulations for Table 3 substances. Under this aspect of the CalARP program, the County is required to make a determination regarding whether a Risk Management Plan (RMP) will be required of SLAC. As of CY99 year-end, the County had not made its determination.

If the County makes a determination that a RMP is necessary, then the County is required to give SLAC a minimum of 12 months, and a maximum of 36 months, to submit the RMP. In the event an RMP is required, at minimum SLAC will need to prepare offsite consequence analyses of worst case and alternative release scenarios for its registered CalARP chemicals, accident histories for the registered chemicals, and general descriptions of its prevention programs.

\subsection{Water Protection Programs}

\subsubsection{Clean Water Act}

The Federal Water Pollution Control Act, also referred to as the Clean Water Act (CWA), was enacted nearly thirty years ago in order to halt the degradation of our nation's waters. Amendments to the CWA in 1972 established the National Pollutant Discharge Elimination System, which regulates discharges of wastewater from point sources such as Publicly Owned Treatment Works and categorically regulated industrial facilities such as electroplating shops. In 1987, the CWA was amended again to include non-point source discharges such as stormwater run-off from industrial, municipal, and construction activities. The CWA is the primary driver behind the SLAC water compliance programs. See Section 5 for information on groundwater. 


\subsubsection{Surface Water}

Federal regulations allow authorized states to issue general permits to regulate industrial stormwater, or non-point source discharges. California is an authorized state, and on November 19, 1991, the State Water Resources Control Board adopted the Industrial Activities Stormwater General Permit (General Permit). SLAC filed a Notice of Intent to comply with the General Permit on March 27, 1992. The General Permit was then reissued, effective July 1, 1997.

The Stormwater Pollution Prevention Plan (SWPPP), which includes Best Management Practices (BMPs) and the Monitoring Plan, was revised per the new General Permit, effective July 1, 1997. The annual stormwater report was submitted to the Regional Water Quality Control Board (RWQCB) on July 1, 1999. The goal of the General Permit is to reduce pollution in the waters of the state by regulating the amounts of pollutants in stormwaters associated with industrial activities.

During CY99, SLAC made progress in completing the following items:

- Illicit Connections

A comprehensive survey was performed in 1996. Since then, 89 connections have been eliminated. Two hundred thirty-three known connections remained at the end of 1999 , with an estimated cost of $\$ 800 \mathrm{~K}$ for elimination of these connections.

During CY99, the design work was completed to eliminate the connections inside the PEP tunnel. A consultant will review the project and prioritize areas to be corrected. Environmental Protection and Restoration (EPR) staff is accumulating flow and water sample data.

- Training

During CY99, EPR staff provided Stormwater BMP training to approximately 70 employees from the Facilities and Plant Engineering Departments.

- Storm Drain Installation

To reduce the amount of rainwater entering the renovated Master Substation, funding was approved for the installation of a storm drain north of Building 16. Phase one of the project, the drain installation from Building 15 to the corner of Sector 30 was completed in CY99.

- Inspections

In CY99, inspection procedures and forms were prepared by EPR staff and approved by the Facilities Department. These procedures were followed to complete the comprehensive inspection of July 1999. Three hundred and twenty catch basins were inspected. Of these, 22 catch basins were cleaned in the fall of 1999, and 14 were identified as needing new covers.

- Funding

Generating environmental project funding through the Activity Data Sheet (ADS) process has been successful. The ADS process is a method to compile and prioritize projects with potential safety and environmental impacts. Elimination of illicit connections, controlling erosion, secondary containments, and sanitary sewer assessments are among the projects receiving funding. 


\subsubsection{Stormwater Monitoring Program}

SLAC's stormwater monitoring program consists of:

1. Two stormwater sampling events per wet season.

2. Monthly visual observations during the wet season.

3. Quarterly visual observations during the dry season.

4. A comprehensive annual site inspection.

During the 1998/1999 wet season (October-May), SLAC analyzed stormwater run-off samples for $\mathrm{pH}$, specific conductance, total petroleum hydrocarbons (TPH) as diesel and motor oil, polychlorinated biphenyls (PCBs), heavy metals, and radioactivity.

There are no enforceable limits, but rather numerical objectives which apply to the data collected for this program based on the RWQCB Basin Plan. The data are used as a general reference for determining whether SLAC appears to be generating stormwater pollutants and whether implementation of BMPs have been effective. Autosamplers were employed for sampling and proved to be a useful asset.

The four sampling locations, as shown in Figure 3-1 on page 30, are identified as:

- Main Gate.

- Northeast Adit.

- IR-6.

- IR-8.

The Main Gate and Northeast Adit watersheds are not, by definition, Industrial Activities areas, unlike the areas discharging at IR-6 and IR-8. IR- 6 receives stormwater contributions from the Research Yard, which includes the Stanford Synchrotron Radiation Laboratory (SSRL) and the Positron-Electron Project (PEP) ring. IR-8 collects water from the campus, fabrication, and Master Substation areas of the facility. Stormwater results are shown in Table 3-2 on page 31 .

Heavy flows of rain mobilized sediment and increased groundwater flows. Straw bales were used extensively to minimize sediment transport into catch basins. As of July 1 , 1999 , fourteen of the original seventeen erosion control projects identified were completed, along with two projects identified after the original list was generated.

These projects ranged from placing riprap in an unlined channel to cleaning out the stormdrain lines in the Research Yard. The other nine projects are either in progress, awaiting regulatory approval or under the jurisdiction of another entity, such as the California Department of Transportation or the Stanford Management Company.

Natural drainages traverse the SLAC facility at two points along the linac: Sector 14 and Sector 18. Erosion and sediment control projects have been completed for both drainages.

Given the complex and time-consuming permitting process, SLAC is looking into developing an agreement with the U.S. Fish and Wildlife Service to facilitate long-term management of sensitive species in natural drainages. 


\subsubsection{Metals}

Metals may be both naturally occurring and anthropogenic. The metals that may be present due to human activities or industrial processes are

- Cadmium

- Chromium

- Copper

- Nickel

- Lead

- Silver

- Zinc

Some metals may be due to vehicle emissions associated with:

- Motor oil.

- Coolant drippings.

- Brake linings.

- Tire fines (minute particles produced as vehicle tires wear down).

Although numerical standards do not exist for stormwater, concentrations reported are consistently low, and are similar to those seen in industrial wastewater samples, which are well within regulatory limits.

\subsubsection{Total Suspended Solids}

Significant levels of suspended silt are generated when it rains. Levels of Total Suspended Solids (TSS) continued to vary greatly with each storm event.

TSS values were consistently low, ranging from 5.3 to $68 \mathrm{mg} / \mathrm{l}$. The elevated concentrations measured the previous fall at IR- 6 did not recur.

\subsubsection{TPH as D iesel}

All of SLAC's regular sampling stations receive run-off from paved areas such as roads and parking lots. However, no TPH was detected in this season's samples, possibly due to dilution from the substantial rainfall.

\subsubsection{PCBs}

PCBs were below detection limits for both rounds of sampling at IR-6 and IR-8. These are the only two locations monitored for PCBs. See Table 3-2 on page 31 for stormwater data. 


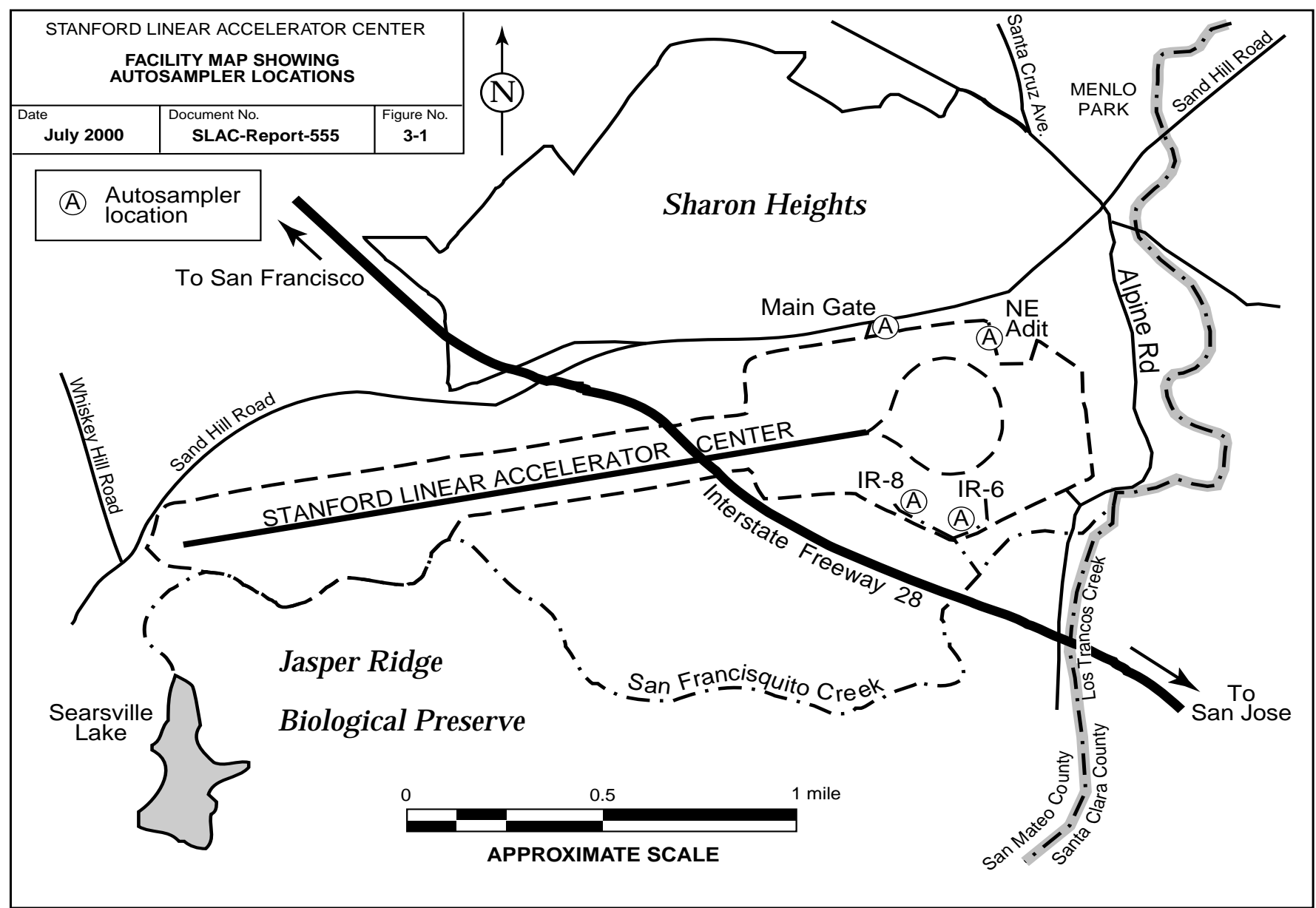


Table 3-2 Stormwater Data for 1998-1999 Storm Season

\begin{tabular}{|c|c|c|c|c|c|c|c|c|}
\hline \multirow[b]{2}{*}{ Date } & \multicolumn{2}{|c|}{ Main Gate } & \multicolumn{2}{|c|}{ North Adit } & \multicolumn{2}{|c|}{ IR-6 } & \multicolumn{2}{|c|}{ IR-8 } \\
\hline & January 18 & March 14 & January 15 & March 14 & January 18 & March 3 & October 25 & March 8 \\
\hline Parameter $^{a}$ & $\begin{array}{l}\text { First Storm } \\
\text { Event }\end{array}$ & $\begin{array}{l}\text { Second Storm } \\
\text { Event }\end{array}$ & $\begin{array}{l}\text { First Storm } \\
\text { Event }\end{array}$ & $\begin{array}{c}\text { Second Storm } \\
\text { Event }\end{array}$ & $\begin{array}{c}\text { First Storm } \\
\text { Event }\end{array}$ & $\begin{array}{l}\text { Second Storm } \\
\text { Event }\end{array}$ & $\begin{array}{c}\text { First Storm } \\
\text { Event }\end{array}$ & $\begin{array}{c}\text { Second Storm } \\
\text { Event }\end{array}$ \\
\hline \multicolumn{9}{|l|}{ Metals $^{\mathbf{b}}$} \\
\hline Cadmium & $<0.0010^{c}$ & $<0.0010$ & $<0.0010$ & $<0.0010$ & $<0.0010$ & $<0.0010$ & $<0.0010$ & 0.0015 \\
\hline Chromium & 0.0058 & 0.0022 & 0.0048 & 0.0026 & 0.0035 & 0.0011 & 0.0036 & 0.0030 \\
\hline Copper & 0.011 & 0.0068 & 0.017 & 0.0043 & 0.011 & 0.018 & 0.032 & 0.014 \\
\hline Lead & 0.0068 & $<0.0020$ & 0.0047 & $<0.0020$ & $<0.0020$ & $<0.0020$ & 0.010 & 0.002 \\
\hline Nickel & $<0.12$ & 0.010 & 0.074 & 0.0073 & $<0.005$ & $<0.005$ & $<0.100$ & 0.023 \\
\hline Silver & $<0.0010$ & $<0.0010$ & $<0.0010$ & $<0.0010$ & $<0.0010$ & $<0.0010$ & $<0.0010$ & $<0.0010$ \\
\hline Zinc & 0.068 & 0.043 & 0.043 & 0.021 & 0.10 & $<0.25$ & 0.44 & 0.0800 \\
\hline \multicolumn{9}{|l|}{ Non-Metals } \\
\hline $\mathrm{TSS}^{\mathrm{d}}$ & 20 & 28 & 9.6 & 68 & 7.0 & 5.3 & 31 & 15 \\
\hline $\mathrm{TPH}^{\mathrm{e}}$ & $<5.0$ & $<5.0$ & $<5.0$ & $<5.0$ & $<5.0$ & $<5.0$ & $<5.0$ & $<5.0$ \\
\hline $\mathrm{PCBs}^{\mathrm{f}}$ & $\mathrm{NS}^{\mathrm{g}}$ & NS & $\mathrm{N}^{\mathrm{g}}$ & NS & $<0.0035^{h}$ & $<0.0035$ & $<0.035^{\mathrm{i}}$ & $<0.0035$ \\
\hline $\mathrm{pH}$ (no units) & 7.36 & 7.50 & 8.01 & 7.69 & 7.36 & 7.37 & 6.60 & 7.72 \\
\hline $\begin{array}{l}\text { Specific Conductance } \\
(\text { umhos } / \mathrm{cm})^{\mathrm{j}}\end{array}$ & 220 & 390 & 3400 & 220 & 100 & 68 & $\mathrm{NS}^{\mathrm{g}}$ & 620 \\
\hline
\end{tabular}

a All values in milligrams per liter $(\mathrm{mg} / \mathrm{l})$ unless otherwise noted.

b Metals results represent total concentrations.

c " $<$ "symbol denotes less than a reporting limit.

d $\quad$ TSS $=$ Total Suspended Solids.

e TPH = Total Petroleum Hydrocarbons.

f $\mathrm{PCBs}=$ Polychlorinated Biphenyls.

g $\mathrm{NS}=$ Not Sampled for this parameter

h Reporting Limit (RL) of $0.0035 \mathrm{mg} / \mathrm{l}$ for PCBs represents sum of individual RLs of $0.005 \mathrm{mg} / \mathrm{l}$ for each of 7 Aroclors.

Non-detected PCB value of $<0.035 \mathrm{mg} / \mathrm{l}$ reflects raised reporting limit due to matrix interference.

Umhos $/ \mathrm{cm}=$ micromhos per centimeter 


\subsubsection{Industrial and Sanitary Wastewater}

SLAC currently operates under three separate Mandatory Wastewater Discharge Permits. These permits set discharge limits for the sanitary sewer and are in effect from April 1, 1997 until they expire on March 31, 2002.

The SLAC industrial and sanitary wastewaters are treated by the South Bayside System Authority (SBSA) in Redwood City, California before being discharged to San Francisco Bay.

The three active SLAC wastewater discharge permits are:

1. WB 970401-F, which regulates SLAC as a whole, including industrial and sanitary wastewaters.

2. WB 970401-P, which regulates operations at the Rinse Water Treatment Plant (RWTP).

3. WB 970401-HX, which regulates operations at the Batch Treatment Plant (BTP).

Permit requirements for SLAC include:

1. Semi-annual sampling for seven heavy metals, Total Toxic Organics (TTO), and $\mathrm{pH}$ at the RWTP.

2. Semi-annual sampling for cyanide at the final rinse tank for the Plating Shop cyanide treatment tank.

3. Semi-annual sampling for seven heavy metals, Total Toxic Organics (TTO), and $\mathrm{pH}$ at the BTP.

4. Signs posted throughout the site advising personnel not to discharge non-permitted material to the sanitary sewer and providing emergency response numbers should there be an accidental release.

5. Quarterly sampling for seven heavy metals and $\mathrm{pH}$ at the Sand Hill Road Flow Meter Station.

SLAC discharged a total of 14,139,102 gallons of wastewater to the sanitary sewer system in 1999, an average of 38,737 gallons per day. The total volume represents a $31 \%$ decrease relative to the CY98 volume. This reduction stems in part from sustained efforts to comply with the volume limit delineated in the Total Facility Discharge Permit, discussed below. In CY99, SLAC's Sanitary Wastewater Monitoring Program consisted of the following three permits:

\subsubsection{Total Facility Discharge Permit}

The Total Facility Discharge Permit (Permit No. WB 970401-F) covers SLAC's total ${ }^{1}$ contribution to the sanitary sewer, including the combined flow from the RWTP and all other wastewater discharges on-site.

SBSA monitors the discharge quarterly to ensure compliance with the permit. SLAC split samples with SBSA during these monitoring events and analyzes them to compare results for quality assurance purposes. All analytical results from samples collected in CY99 are presented in Table 3-3 on page 33 and Table 3-4 on page 34 .

${ }^{1}$ A small portion of SLAC's domestic wastewater is carried off-site via the sanitary sewer on the south side of the facility. Historically, the volume of this wastewater is considered by the sewage authorities to be trivial, and is not routinely monitored. However, a flow meter is scheduled to be installed near the southern facility boundary in CY00 to quantify the southern discharge. 
Table 3-3 CY99 Fow Meter Station Sampling Data (First Half)

\begin{tabular}{|c|c|c|c|c|c|c|c|c|c|}
\hline \multirow[b]{2}{*}{ Parameter } & \multirow[b]{2}{*}{$\begin{array}{c}\text { DISCHARGE } \\
\text { UMIT' } \\
\text { (Ib/day) }\end{array}$} & \multicolumn{4}{|c|}{ February 3} & \multicolumn{4}{|c|}{ April 20} \\
\hline & & $\begin{array}{c}\text { SLAC } \\
\text { Monitoring } \\
\text { Results } \\
(\mathbf{m g} / \mathbf{l})\end{array}$ & $\begin{array}{c}\text { SBSA } \\
\text { Monitoring } \\
\text { Results } \\
(\mathbf{m g} / \mathbf{l})\end{array}$ & $\begin{array}{c}\text { SLAC } \\
\text { Calculated } \\
\text { Results }^{b} \\
\text { (Ib/day) }\end{array}$ & $\begin{array}{c}\text { SBSA } \\
\text { Calculated } \\
\text { Results } \\
\text { (Ib/day) }\end{array}$ & $\begin{array}{c}\text { SLAC } \\
\text { Monitoring } \\
\text { Results } \\
(\mathbf{m g} / \mathbf{l})\end{array}$ & $\begin{array}{c}\text { SBSA } \\
\text { Monitoring } \\
\text { Results } \\
(\mathbf{m g} / \mathbf{l})\end{array}$ & $\begin{array}{c}\text { SLAC } \\
\text { Calculated } \\
\text { Results } \\
\text { (lb/day) }\end{array}$ & $\begin{array}{c}\text { SBSA } \\
\text { Calculated } \\
\text { Results } \\
\text { (lb/day) }\end{array}$ \\
\hline \multicolumn{10}{|l|}{ Metals (mg/l) } \\
\hline Cadmium & 0.036 & 0.0014 & $<0.0070^{\mathrm{c}}$ & 0.0005 & $<0.0027$ & 0.0071 & $<0.0070$ & 0.0031 & $<0.0031$ \\
\hline Chromium & 0.48 & 0.0042 & $<0.0200$ & 0.0016 & $<0.0078$ & 0.0066 & $<0.0200$ & 0.0029 & $<0.0088$ \\
\hline Copper & 0.35 & 0.0650 & 0.1100 & 0.0255 & 0.0431 & 0.090 & 0.1400 & 0.0398 & 0.0619 \\
\hline Lead & 0.33 & 0.0035 & $<0.0500$ & 0.0014 & $<0.0196$ & 0.012 & $<0.0500$ & 0.0053 & $<0.0221$ \\
\hline Nickel & 0.064 & 0.0270 & $<0.0300$ & 0.0106 & $<0.0117$ & 0.024 & 0.1000 & 0.0106 & 0.0442 \\
\hline Silver & 0.076 & $<0.0010$ & 0.0500 & $<0.0004$ & 0.0196 & $<0.0010$ & $<0.0030$ & $<0.00004$ & $<0.0013$ \\
\hline Zinc & 0.7 & 0.1100 & 0.1070 & 0.0431 & 0.0419 & 0.19 & 0.2060 & 0.0841 & 0.0911 \\
\hline \multicolumn{10}{|l|}{ Non-Metals } \\
\hline $\mathrm{pH}$ & $6.0-12.5^{\mathrm{d}}$ & $\mathrm{NS}^{\mathrm{e}}$ & 8.10 & $\mathrm{NA}^{\mathrm{f}}$ & NA & 7.46 & 8.00 & NA & NA \\
\hline Flow (gpd) & 62,175 & 46,953 & 46,953 & NA & NA & 53,043 & 53,043 & NA & NA \\
\hline
\end{tabular}

a Discharge Limit $=$ SBSA Annual Average Limit (determined by comparison of limit with the average of all samples collected during each one-year term of this permit)

b Converted Results in lb/day $=($ gal $/$ day $)(\mathrm{mg} / \mathrm{l}$ pollutant $)(8.34 \mathrm{lb} / \mathrm{gal})\left(10 \mathrm{E}^{6} \mathrm{l} / \mathrm{mg}\right)$

c " $<$ 'Symbol denotes less than a reporting limit

$=$ Daily Maximum, rather than Annual Average Limit

e NS = Not Sampled

f $\mathrm{NA}=$ Not applicable 
Table 3-4 CY99 Fow Meter Station Sampling Data (Second Half)

\begin{tabular}{|c|c|c|c|c|c|c|c|c|c|}
\hline \multirow[b]{2}{*}{ Parameter } & \multirow[b]{2}{*}{$\begin{array}{c}\text { DISCHARGE } \\
\text { UMIT' } \\
\text { (lb/day) }\end{array}$} & \multicolumn{4}{|c|}{ July 20} & \multicolumn{4}{|c|}{ November 16} \\
\hline & & $\begin{array}{c}\text { SLAC } \\
\text { Monitoring } \\
\text { Results } \\
\text { (mg/l) }\end{array}$ & $\begin{array}{c}\text { SBSA } \\
\text { Monitoring } \\
\text { Results } \\
\text { (mg/l) }\end{array}$ & $\begin{array}{c}\text { SLAC } \\
\text { Calculated } \\
\text { Results }^{\text {b }} \\
\text { (lb/d) }\end{array}$ & $\begin{array}{c}\text { SBSA } \\
\text { Calculated } \\
\text { Results } \\
\text { (lb/d) }\end{array}$ & $\begin{array}{c}\text { SLAC } \\
\text { Monitoring } \\
\text { Results } \\
\text { (mg/l) }\end{array}$ & $\begin{array}{c}\text { SBSA } \\
\text { Monitoring } \\
\text { Results } \\
\text { (mg/l) }\end{array}$ & $\begin{array}{l}\text { SLAC } \\
\text { Calculated } \\
\text { Results } \\
\text { (lb/d) }\end{array}$ & $\begin{array}{c}\text { SBSA } \\
\text { Calculated } \\
\text { Results } \\
\text { (lb/d) }\end{array}$ \\
\hline \multicolumn{10}{|l|}{ Metals (mg/l) } \\
\hline Cadmium & 0.036 & $<0.0010^{\mathrm{c}}$ & $<0.0070$ & 0.0005 & $<0.0034$ & 0.0009 & $<0.070$ & $0.0003^{\mathrm{d}}$ & $<0.0012$ \\
\hline Chromium & 0.48 & 0.0030 & 0.0200 & 0.0015 & 0.0097 & $<0.0032$ & $<0.0200$ & $<0.0011$ & $<0.0034$ \\
\hline Copper & 0.35 & 0.10 & 0.1600 & 0.0484 & 0.0775 & 0.057 & 0.0800 & 0.0193 & 0.0275 \\
\hline Lead & 0.33 & 0.0081 & $<0.0500$ & 0.0039 & $<0.0242$ & 0.0065 & $<0.0500$ & 0.0022 & $<0.0086$ \\
\hline Nickel & 0.064 & 0.015 & $<0.0300$ & 0.0073 & $<0.0145$ & 0.011 & $<0.0300$ & 0.0037 & $<0.0051$ \\
\hline Silver & 0.076 & $<0.0010$ & $<0.0030$ & 0.0005 & $<0.0015$ & $<0.0027$ & $<0.0030$ & $<0.0009$ & $<0.0005$ \\
\hline Zinc & 0.7 & 0.14 & 0.1340 & 0.0649 & 0.0649 & 0.34 & 0.2940 & 0.12 & 0.10 \\
\hline \multicolumn{10}{|l|}{ Non-Metals } \\
\hline $\mathrm{pH}$ & $6.0-12.5^{\mathrm{e}}$ & 7.93 & 8.30 & NA & NA & 8.32 & 8.30 & NA & NA \\
\hline Flow (gpd) & 62,175 & 58,062 & 58,062 & $N A^{f}$ & $\mathrm{NA}$ & 41,133 & 41,133 & NA & NA \\
\hline
\end{tabular}

a Discharge Limit =SBSA Annual Average Limit (determined by comparison of limit with the average of all samples collected during each one-year term of this permit)

b Calculated Results in lb/day + (gal/day)(mg/l pollutant)(8.34 lb/gal)(10E-6 l/mg)

c "<'Symbol denotes less than a reporting limit

d Value used in calculation is between the Practical Quantitation Limit (PQL) and the Method Detection Limit (MDL).

e =Daily Maximum, rather than Annual Average Limit

f $\mathrm{NA}=$ Not applicable 


\subsubsection{Rinse Water Treatment Plant (Permit No. W B 970401-P)}

SLAC conducted metal finishing operations in an on-site electro plating shop during CY99. Rinsewater baths from the Plating Shop were processed through the RWTP prior to being discharged to the sanitary sewer. The RWTP discharged 1.05 million gallons of effluent to the sanitary sewer in CY99. Effluent from the RWTP consistently met required federal metal finishing pre-treatment standards, which are specified in the permit.

As required by federal standards, SBSA periodically monitored the metal finishing discharges, as well as the rinsewater from a cyanide treatment process in the Plating Shop. Again, SLAC and SBSA split samples from the RWTP and cyanide tank for quality assurance purposes. SBSA and SLAC's analytical results for CY99 are presented in Table 3-5 on page 36. As usual, the results indicate that SLAC continues to operate in compliance with applicable regulations

\subsubsection{Batch Treatment Plant (Permit N o. W B 970401-HX)}

The BTP is permitted to treat effluent from the heat-exchanger descaling operation prior to discharge to the sanitary sewer. It accumulates batches of up to 4,000 gallons, which are then treated to remove metals and adjust $\mathrm{pH}$. The BTP was operated once in CY99, discharging approximately 1,800 gallons of effluent to the sanitary sewer in one operation.

\subsubsection{Sanitary Sewer Assessment}

A sanitary sewer assessment was conducted by EPR during CY99. The purpose of this project was to address periodic sewer overflows and to assess the degree of compliance with SLAC's stormwater and wastewater discharge permits, as well as with the local sanitary district's entitlement contract.

Pipe capacities and conditions were assessed using temporary flow monitoring, smoke testing, and closed-circuit television inspections. The findings of this assessment included:

- A better understanding of discharge flow, which led to the planned installation of a permanent flow meter at the Alpine Road sanitary sewer connection and an upgrade of the existing flow meter at the Sand Hill Road connection.

- The development of a prioritized sewer system repair list that the Facilities Department began to implement.

- Confirmation that, other than those flowing into the Research Yard and ring tunnels, very few sources of rainwater exist that flow to the sanitary sewer.

- Recommendations for preventive maintenance activities and schedules, including more frequent root cutting, routine line cleaning, irrigation overflow control, and additional inspection work using closedcircuit television cameras. 
Table 3-5 CY99 Rinse Water Treatment Plant Sampling Data

\begin{tabular}{|c|c|c|c|c|c|c|c|c|}
\hline \multirow[b]{3}{*}{ Constituent } & \multirow[b]{3}{*}{$\begin{array}{l}\text { Federal } \\
\text { Daily } \\
\text { Maximum } \\
\text { (mg/l) }\end{array}$} & \multirow[b]{3}{*}{$\begin{array}{l}\text { Federal } \\
\text { Monthly } \\
\text { Average } \\
\text { (mg/l) }\end{array}$} & \multirow{2}{*}{\multicolumn{2}{|c|}{$\begin{array}{c}\text { First Round } \\
\text { March } 4\end{array}$}} & \multirow{2}{*}{\multicolumn{2}{|c|}{$\begin{array}{r}\text { Second Round } \\
\text { October } 29\end{array}$}} & \multirow{2}{*}{\multicolumn{2}{|c|}{$\begin{array}{r}\text { Third Round } \\
\text { December } 7\end{array}$}} \\
\hline & & & & & & & & \\
\hline & & & $\begin{array}{c}\text { SLAC } \\
\text { Monitoring } \\
\text { Results } \\
\text { (mg/l) }\end{array}$ & $\begin{array}{c}\text { SBSA } \\
\text { Monitoring } \\
\text { Results } \\
(\mathbf{m g} / \mathbf{l})\end{array}$ & $\begin{array}{c}\text { SLAC } \\
\text { Monitoring } \\
\text { Results } \\
(\mathbf{m g} / \mathbf{l})\end{array}$ & $\begin{array}{c}\text { SBSA } \\
\text { Monitoring } \\
\text { Results } \\
\text { (mg/l) }\end{array}$ & $\begin{array}{c}\text { SLAC } \\
\text { Monitoring } \\
\text { Results } \\
(\mathbf{m g} / \mathbf{l})\end{array}$ & $\begin{array}{c}\text { SBSA } \\
\text { Monitoring } \\
\text { Results } \\
(\mathrm{mg} / \mathrm{l})\end{array}$ \\
\hline \multicolumn{9}{|l|}{ Metals $\left(\mathrm{mg} / \mathrm{I}^{\mathrm{a}}\right)$} \\
\hline Cadmium & 0.69 & 0.26 & $<0.0010 \mathrm{~b}$ & $<0.007$ & $0.00029^{c}$ & $N S^{d}$ & $<0.000046$ & $N S^{d}$ \\
\hline Chromium & 2.77 & 1.71 & 0.016 & $<0.02$ & 0.02 & $N S^{d}$ & $<0.0032$ & $N S^{d}$ \\
\hline Copper & 3.38 & 2.07 & 0.042 & 0.2900 & 0.161 & $N S^{d}$ & 0.037 & $N S^{d}$ \\
\hline Lead & 0.69 & 0.43 & 0.0025 & $<0.005$ & $0.00086^{\mathrm{c}}$ & $N S^{d}$ & $<0.0004$ & $N S^{d}$ \\
\hline Nickel & 3.98 & 2.38 & 0.34 & 0.1800 & 0.102 & $N S^{d}$ & 0.014 & $\mathrm{NS}^{\mathrm{d}}$ \\
\hline Silver & 0.43 & 0.24 & 0.011 & $<0.003$ & 0.018 & $N S^{d}$ & 0.011 & $\mathrm{NS}^{\mathrm{d}}$ \\
\hline Zinc & 2.61 & 1.48 & $<0.020$ & 0.0560 & $<0.00089$ & $N S^{d}$ & $<0.00089$ & $N S^{d}$ \\
\hline \multicolumn{9}{|l|}{ Non-Metals } \\
\hline Cyanide (mg/l) & 1.20 & 0.65 & $<0.010$ & 0.0130 & 0.012 & $N S^{d}$ & 0.03 & $N S^{d}$ \\
\hline $\mathrm{TTO}^{\mathrm{e}, \mathrm{h}}$ & 2.13 & $N^{f}$ & 0.0072 & 0.0125 & $0.144^{\mathrm{g}}$ & $N S^{d}$ & 0.00634 & $\mathrm{NS}^{\mathrm{d}}$ \\
\hline TTO (11-2-99) & & & & & 0.014 & 0.0169 & & \\
\hline $\mathrm{pH}$ & $6.0--12.5$ & $\mathrm{NA}^{\mathrm{d}}$ & 7.18 & 7.70 & 9.33 & $N S^{d}$ & 8.31 & $\mathrm{NS}^{\mathrm{d}}$ \\
\hline
\end{tabular}

$\mathrm{mg} / \mathrm{l}=$ milligrams per liter (= parts per million)

$<=$ Precedes reporting limits for individual parameters, for example, non-detected.

c Value reported is between the Practical Quantitation Limit (PQL) and the Method Detection Limit (MDL)

NS $=$ Not Sampled

TTO $=$ Total Toxic Organics (analyzed by EPA Method 8240)

$\mathrm{N}=$ Not Applicable

October TTO value of 0.144 includes $0.13 \mathrm{mg} / \mathrm{l}$ as methylene chloride (lab error).

h Chloroform and methylene chloride were the primary TTOs detected in 1999. 


\subsubsection{Endangered Species Act}

Based on information provided by the California Department of Fish and Game and the U. S. Department of Fish and Wildlife, 14 animal species and 13 plant species occurring in San Mateo County are currently listed as endangered, threatened, proposed, or of concern. Of these, three of the animal species may occur on or immediately adjacent to the SLAC leaseholding: the California red-legged frog (Rana aurora, subspecies draytonii), the San Francisco garter snake (Thamnophis sirtalis tetrataenia), and the steelhead trout (Oncorhynchus mykiss). All three are aquatic or semi-aquatic species associated with San Francisquito Creek, which is located south of and roughly parallel to the linac. The creek receives run-off from SLAC via three natural drainages, although no part of the creek is on the SLAC leaseholding. SLAC and San Francisquito Creek are shown in Figure 3-2 on page 38 .

The red-legged frog, which was granted threatened status at the federal level in August 1997, is common in and around San Francisquito Creek. However, this frog is truly amphibious and can be found as far as one mile from the nearest water body. Accordingly, it may occur at SLAC, and has figured prominently in the permitting process for erosioncontrol and sediment-control projects in the on-site natural drainages. However, no verified sitings of red-legged frogs have been recorded to date on the SLAC leaseholding. Stanford University's Center for Conservation Biology routinely performs biological surveys on Stanford lands; the first such surveys were done at SLAC in CY99, and a report is expected in summer of 2000.

Historically, the San Francisco garter snake has occurred on and around the SLAC facility. However, this common name encompasses several subspecies, and the subspecies designated as endangered by the federal government ( $T$. s. tetrataenia) intergrades with a similar subspecies (T. s. infernalis) in southeastern San Mateo County and northwestern Santa Clara County. In other words, the SLAC facility lies near the northeastern edge of the endangered subspecies' distribution, rather than near its center. This distributional limit, coupled with specific habitat requirements, makes the endangered subspecies unlikely to occur at SLAC.

Steelhead populations are increasing in the creek, due in large part to the efforts of the local watershed consortium established under the Coordinated Resource Management and Planning process, of which Stanford University and SLAC are founding members. However, this species is highly unlikely to occur on the SLAC leaseholding, due to the seasonal water flow patterns, the small sizes of the on-site drainages, and downstream drainage modifications by other Stanford University leaseholders.

\subsubsection{Federal Insecticide, Fungicide, and Rodenticide Act}

The Federal Insecticide, Fungicide, and Rodenticide Act regulates pesticide use in the United States. The term "pesticide" refers to insecticides, rodenticides, and herbicides. SLAC uses licensed subcontractors to apply "registered use" pesticides. SLAC personnel apply "general use" pesticides only. In CY99, SLAC used pesticide and herbicide handling and storage procedures that were developed in CY94. These procedures were incorporated into the subcontracts for landscape maintenance and pest control, and have been implemented by the subcontractors. 


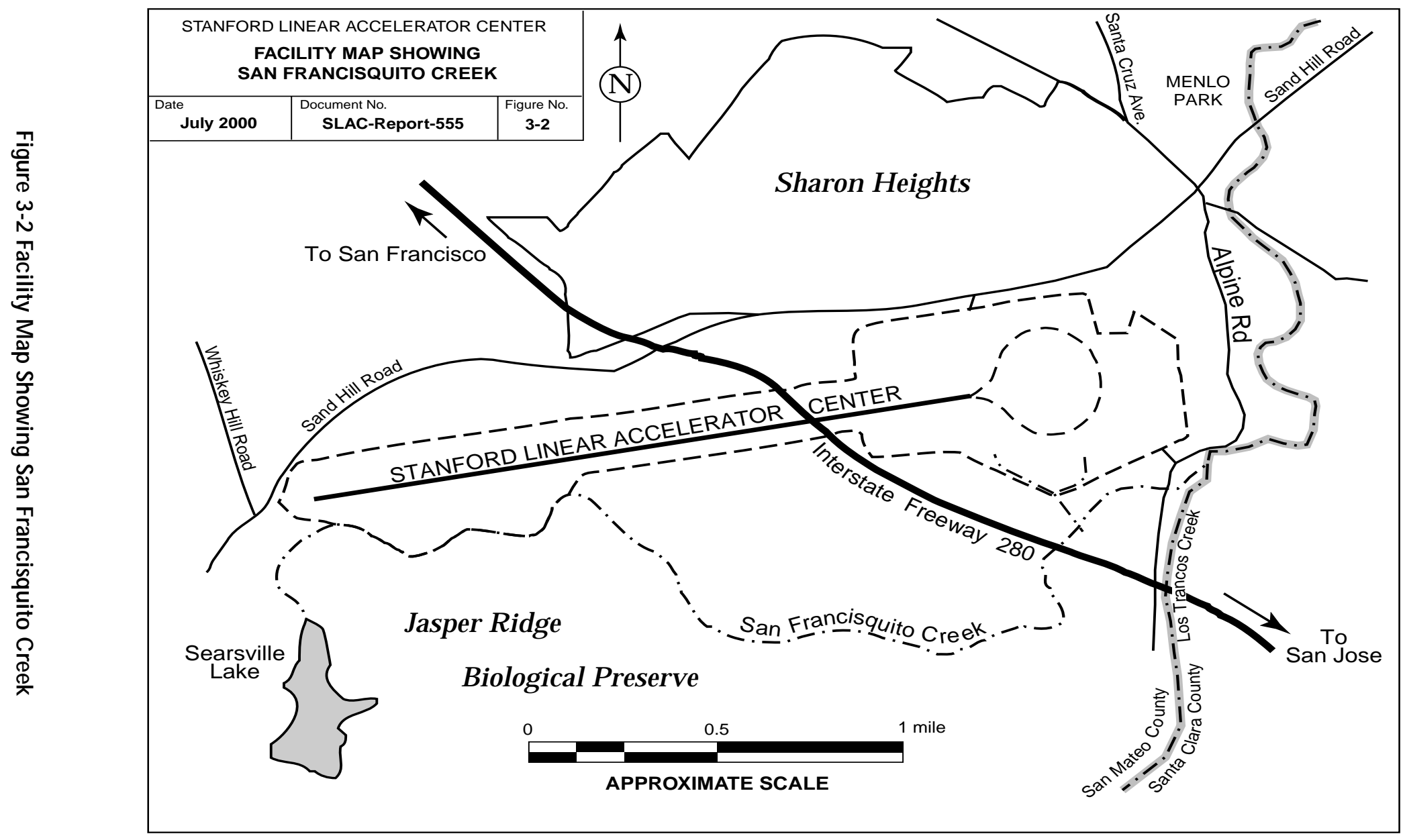




\subsubsection{Executive O rder 11990, Protection of Wetlands}

As part of an environmental assessment conducted in CY91, SLAC had a subcontractor perform a survey to determine whether any area(s) within or next to the SLAC facility should be formally designated as wetlands, which are specifically protected under Section 404 of the CWA. The field survey and evaluation were performed using established federal guidance.

According to the survey, the IR-8 drainage ditch showed characteristics of wetlands, but a definitive evaluation was not possible because of continuing drought conditions and because the study was performed in the fall, when reproductive structures on aquatic vegetation are generally absent.

The portion of the IR- 8 drainage channel that represents the majority of the potential wetlands at and around SLAC is approximately 4,000 square feet, less than one-tenth of an acre. By comparison, in practice the US Army Corps of Engineers (COE) uses ten acres as their functional cutoff for "significant" wetlands.

Representatives from the COE, the RWQCB, and the DFG have been on-site to observe erosion-related problems at Sectors 14 and 18. The COE stated that the Sector 18 area appeared to be a wetland, and that the Corps would treat it as such for permitting purposes. Nevertheless, a follow-up to the 1991 survey would be required for a definitive determination. In the meantime, SLAC has operated proactively under the assumption that wetlands do exist within and adjacent to the facility boundaries.

\subsection{Waste Minimization}

\subsubsection{Site-Wide Program Planning and D evelopment}

SLAC has been implementing its waste minimization program in accordance with established waste minimization plans. The plans address the reduction of specific hazardous waste streams in accordance with regulations and provide strategies to increase employee awareness on waste reduction measures for non-hazardous and low-level radioactive wastes as well as hazardous wastes.

Implementation of waste minimization and pollution prevention is a SLAC line responsibility. Some of the highlights of SLAC implementation of waste minimization and pollution prevention measures are discussed in Section 3.4.2, below.

SLAC has a Waste Minimization and Pollution Prevention Citizens Committee. The committee is composed of a representative from each division, an ES\&H Coordinator from the Research Division, and the ES\&H Waste Minimization and Pollution Prevention Coordinator. The committee reviews waste streams and identifies pollution prevention opportunities.

\subsubsection{Waste Minimization and Pollution Prevention Activities/Implementation}

In CY99 SLAC continued to make progress in the implementation of waste reduction measures for non-hazardous (municipal) wastes, hazardous wastes, and low-level radioactive wastes. An overview of the program activities and implemented waste reduction measures follows. 


\subsubsection{Site-wide Recycling}

SLAC implemented a site-wide program for recycling of various paper, corrugated cardboard, and beverage cans and bottles based on its CY98 pilot recycling project.

\subsubsection{N on-hazardous Waste Reduction}

The quantities of non-hazardous waste and the materials recycled or diverted from landfills from 1990 to 1999 are summarized in Figure 3-3. Material recycled or diverted is shown with and without scrap metal recycling to show the contribution of scrap metals. In 1999, SLAC achieved 33 percent diversion without scrap metal and 56 percent diversion with scrap metal.

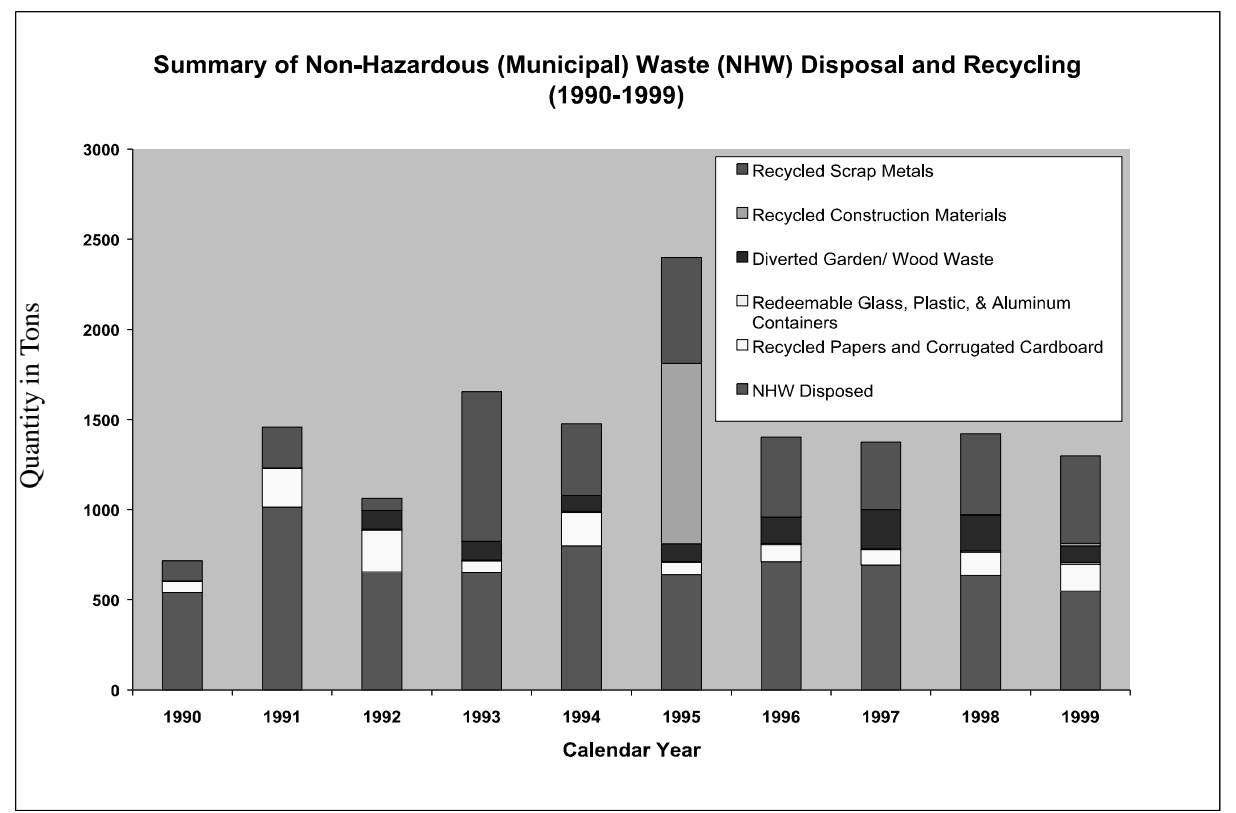

Figure 3-3 Non-Hazardous Waste Summary

\subsubsection{Hazardous Waste}

Hazardous waste has been reduced through a combination of techniques, including:

- Converting empty metal containers and drums to scrap metal.

- Exchanging chemicals with other users (both on and off-site).

- Reusing chemicals.

- Returning unused material back to the vendor or manufacturer.

- Sending electrical equipment off site for re-use by other organizations.

- Treating acid and alkaline wastes in accordance with the California Tiered Permit Program.

Due to the above listed activities, hazardous waste was reduced or reused by more than 32 tons during CY99. 


\subsubsection{Hazardous Waste Reduction}

Figure 3-4 shows the trends in the generation of hazardous waste for three major categories: operational, Toxic Substances Control Act (TSCA), and remediation-related hazardous waste.

Some of the operational hazardous wastes are classified as non-routine due to their one-time or highly infrequent generation. As of CY99, SLAC has reduced its hazardous waste by $61 \%$ relative to 1993 and by $83 \%$ relative to 1990.

TSCA wastes result from removal of old electrical equipment (PCB-containing equipment) and construction practices (asbestos-containing materials). These wastes result from the phasing out of these materials from use in SLAC operations. Remediation wastes are the result of past practices or accidental spills.

TSCA and remediation wastes are expected to decrease over time due to elimination of the sources of PCB and asbestos wastes and by cleanup of wastes from past practices and spills.

\section{Hazardous Waste Generation for Routine and Non-Routine Operations, TSCA, and Remediation (1990 - 1999)}

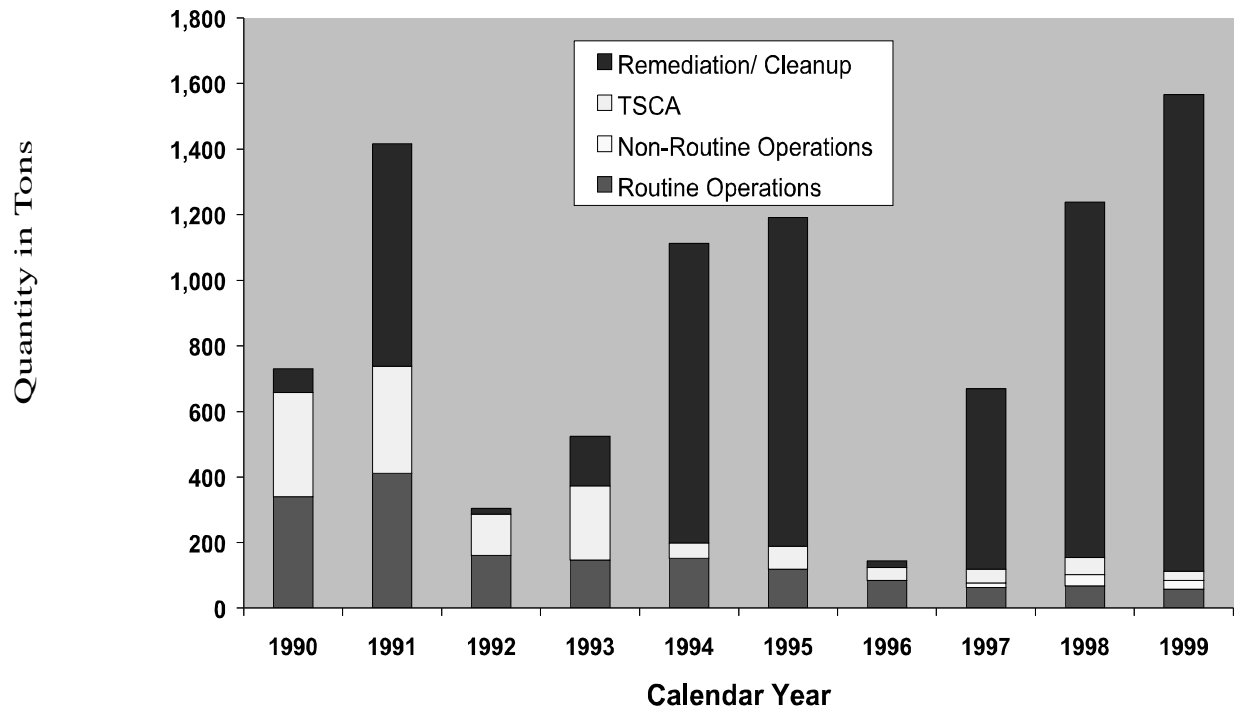

Notes:

o Routine or non-routine operations are associated with research projects, supporting operations, and facility maintenance activities and exclude Toxic Substances Control Act (TSCA) and Remediation wastes. Routine operational hazardous wastes are those from repeated activities. Non-routine operational hazardous waste are those from major one-time projects or activities.

o Non-routine operational hazardous waste in 1991 was due to a major one-tine cleanup activity. Routine and non-routine operations were not tracked in 1991 and are only reported here as routine.

o TSCA waste includes polychlorinated biphenyls (PCBs) from electric equipment replacement and asbestos wastes from building renovations.

o Remediation waste are from site restoration activities, usually removal of soils contaiminated with PCBs, oils, solvents or metals.

Figure 3-4 Hazardous Waste Summary 


\subsubsection{Low-Level Radioactive Waste Reduction}

Although little of the low-level radioactive materials or waste generated at SLAC are routine, SLAC reduces these materials and waste through measures such as segregation and reuse.

The quantities of low-level radioactive wastes are the accumulation of waste generated over years of operation and various construction and decomissioning activities. Some low-level radioactive waste is generated from maintenance operations. This type of waste generation tends to be sporadic.

\subsection{Waste Management}

\subsubsection{Resource Conservation and Recovery Act}

The Resource Conservation and Recovery Act (RCRA) of 1976 provides "cradle-to-grave" authority to regulate hazardous wastes from their generation to their ultimate disposal. This is accomplished through a system of recordkeeping, permitting, monitoring, and reporting.

The primary objective of RCRA is to protect human health and the environment. A secondary objective of RCRA, however, is to conserve valuable material and energy resources by promoting beneficial solid waste management, resource recovery, and resource conservation systems.

In order to meet the second objective, Congress required that the Federal government employ its purchasing power to help create and sustain markets for recycled materials. Under Section 6002 of RCRA, the Federal Government established a program that requires Federal purchasing of specified recycled content products. Aspects of this portion of RCRA are discussed in Section 3.5.2, which covers waste prevention, recyling, and federal acquisition.

The different aspects of RCRA as it relates to hazardous waste management activities at SLAC are discussed in Sections 3.5.1.1 through 3.5.1.4.

\subsubsection{Hazardous Waste Management}

Management of hazardous waste at SLAC is performed by the Hazardous Waste Management Group of the WM Department. SLAC is a generator of hazardous waste and is not permitted to treat hazardous waste or store it for longer than 90 days. The SMC/DHS is the agency responsible for inspecting SLAC as a generator of hazardous waste for compliance with federal, state, and local hazardous waste laws and regulations.

The US DOE Oakland Operations Office, (DOE/OAK) coordinates with the State of California EPA Department of Toxic Substances Control on issues pertaining to radioactive and hazardous waste.

\subsubsection{Hazardous Waste Tracking System}

SLAC utilizes a self-developed, site-specific computerized hazardous waste tracking system (WTS). Hazardous waste containers are tracked from the time they are issued to the generator to eventual disposal off-site. The WTS includes electronic information fields which generate information for the Biennial, Superfund Amendments and Reauthorization Act (SARA) Title III, and TSCA PCB annual reports. 
The majority of hazardous waste generated from operations throughout the site is accumulated in Waste Accumulation Areas (WAAS). Each WAA is managed by a Hazardous Waste and Materials Coordinator, who is provided training and written guidelines on proper management of WAAS. Training includes spill response preparedness, waste minimization, SLAC's wastetracking system, and required "refresher" generator training.

SLAC has the potential to generate radioactive hazardous waste non-routinely. Waste that has been activated with accelerator-induced radioactivity is considered to be hazardous, but, by regulation, is not defined as mixed. The type of waste generated at SLAC is sometimes referred to as "combined waste" by the state of California, indicating that the waste contains both accelerator-induced radioactivity and a state or federal hazardous component.

Historically, SLAC has generated small quantities of activated liquids used for experiments and cleaning of accelerator machine parts. Other machine parts and materials used in support of operations have the potential to become activated. These include metal pipe and fittings that contain regulated components at levels above the regulatory threshold, and cooling-line cleaning solutions.

The generation of combined waste at SLAC, as previously noted, occurs on a non-routine basis. SLAC and the DOE are continuing to assess treatment and disposal options for waste streams in this category as well as opportunities for minimizing the generation of this type of waste.

\subsubsection{Hazardous Waste Treatment}

SLAC currently performs hazardous waste treatment under the State of California Tiered Permit Program (program) using both Permit-by-Rule and Conditional Authorization tier permits. Under this program, SLAC is authorized to treat listed or characteristic hazardous wastes, and currently performs hazardous waste treatment at the BTP and the Rinsewater Treatment Plant (RTP).

Currently, there are two fixed units that have Permit-By-Rule tier permits, and one fixed unit that has a Conditional Authorization permit. Hazardous wastes in these units are the result of waste generated during treatment of:

- Non-hazardous rinse or wastewaters.

- Hazardous wastes specifically authorized by the State of California.

Non-hazardous rinse and wastewaters are treated in these units to ensure the water discharged to the sanitary sewer will meet industrial and sanitary wastewater discharge requirements.

Some wastes (typically acid and alkaline) generated from metal finishing operations are also authorized for treatment. The filtered solids generated in these treatment units are hazardous and are further treated in a sludge dryer to remove water and reduce waste volume. In November 1999, the SLAC Permit-by-Rule (PBR) was inspected by the San Mateo County DHS. The PBR was found to be in compliance with "No violations noted". 


\subsubsection{Hazardous Waste Generator Inspection}

The San Mateo County Division of Environmental Health last conducted a Hazardous Waste Generator Inspection during the period of March through September 1998. The county issued its report in December 1998. From this report, corrective actions were developed and implemented. These actions were detailed in a Certification of Compliance to the County in February 1999. The county stated that it intends to conduct a hazardous waste generator inspection in the first quarter of 2000.

\subsubsection{Waste Prevention, Recycling, and Federal Acquisition}

In earlier years, most of the RCRA Subtitle C Program effort was focused on regulating the management of hazardous waste. The emphasis was shifted on September 14, 1998, when the President signed Executive Order 13101, Greening the Government through Waste Prevention, Recycling, and Federal Acquisition, which required Federal facilities to increase their attention to the purchase of designated products which meet EPA recovered material content requirements.

This year, SLAC received a compliance assistance inspection from the US Environmental Protection Agency - Region 9 as part of a pilot program being conducted by the agency to evaluate Federal facility compliance with Section 6002. The inspection indicated that SLAC was procuring some of the designated vehicular products that did not meet the EPA recovered materials content requirements. EPA encouraged SLAC to review the Comprehensive Procurement Guidelines (CPG) for all designated items and incorporate them in SLAC purchasing procedures.

SLAC is currently reviewing the procurement of designated products in the CPG with the key departments involved with these products. An affirmative procurement program is under development through ES\&H in association with key departments to determine roles and responsibilities and how the departments will implement the program.

\subsection{Hazardous Materials Management}

The Superfund Amendments and Reauthorization Act (SARA) Title III, also known as the Emergency Planning and Community Right-to-Know Act (EPCRA), is primarily directed toward developing an inventory of the information needed to compile the various reports required by EPCRA. These reports also address the implementation requirements for statutes in the State of California (the La Follette and Waters Bills).

On 5/14/99, SLAC submitted a Hazardous Materials Business Plan (HMBP) which details the response in the event of a release of hazardous material. This plan designated an emergency coordinator, described the first response and several levels of escalation, delineated the means by which all mandated notification will be made to the local authority (LA) and local fire department, and described the facility's evacuation, containment, and cleanup capability. The site maps have not changed significantly since the last submittal in 1997.

Under Section 312 of EPCRA, SLAC must provide to the LA and the local fire department, on an annual basis, an annual inventory of hazardous substances that are present in quantities greater than 55 gallons, 500 pounds, or 200 cubic feet. The LA requires a report to be filed for each individual hazardous substance.

Compliance for CY99 was achieved by sending out chemical inventories to the Chemical Inventory Coordinators (CICs). This information was then checked against the chemical inventory database and any discrepancies were checked for verification with the appropriate CIC. 
For a discussion of the TRI reporting requirements under Section 313 of the EPCRA, see Section 3.2.3 on pages 25 and 26. The SARA Title III report, and the State equivalent, HMBP report, were submitted to SMC/DHS for CY99. See Table 3-6 for report information.

Table 3-6 EPCRA Compliance Information

\begin{tabular}{|l|l|c|c|}
\hline Article & Title & Report Required & Report Submitted \\
\hline \hline $302-303$ & Planning Notification & YES & YES \\
\hline 304 & EHS Release Notification & YES & YES \\
\hline $311-312$ & MSDS/Chemical Inventory & YES & YES \\
\hline
\end{tabular}

\subsection{PCB and Tank Management}

\subsubsection{Toxic Substances Control Act}

TSCA regulates equipment that is filled with oil or other dielectric fluids containing PCBs. SLAC has some equipment that falls into this category. PCBs, their use, and their disposal are regulated by TSCA. TSCA regulations include provisions for phasing out PCBs and other chemicals that pose a risk to health or the environment. The EPA is responsible for ensuring that facilities are in compliance with TSCA. The State of California further regulates PCBs as a non-RCRA hazardous waste. No EPA inspections regarding TSCA were conducted at SLAC during CY99.

In CY99, the annual document logs from 1992 to present were compiled and are now located in the EPR Library (Building 299). The site inventory of oil-filled equipment was updated for the Spill Prevention Control and Countermeasure (SPCC) plan. The SPCC plan was prepared by SLAC to prevent, control, and mitigate the discharge of any oil or oil products, as defined in 40CFR112.2.

The Mark II transformer, located at the Collider Experimental Hall (CEH), is designated as the only "PCB Transformer" remaining in the SLAC inventory. At the cost of $\$ 6,000$ to reclassify the transformer, the project is being evaluated.

\subsubsection{Tank Management}

SLAC has no remaining underground storage tanks in use. Petroleum storage tanks with capacities over 10,000 gallons are regulated under Title 40, Code of Federal Regulations, Part 112 (40CFR112), and the "Aboveground Petroleum Storage Act" in the California Health and Safety Code, Division 20, Chapter 6.67. SLAC currently has one diesel tank subject to this Act. 


\subsection{Environmental Q uality Acts}

\subsubsection{National Environmental Policy Act}

SLAC formalized a National Environmental Policy Act (NEPA) program in CY92. Under this program, proposed project and action descriptions are reviewed to determine if NEPA documentation is required. If so, the proper paperwork is prepared and submitted. The project or action is entered in a database and tracked. The resulting draft NEPA document is reviewed by specified SLAC staff for concurrence, and is forwarded to the DOE Site Office for review and approval.

NEPA provides a three-level mechanism to ensure that all environmental impacts of and alternatives to performing a proposed project are considered before it is carried out. The three types of NEPA documentation, in order of increasing complexity, are Categorical Exclusions (CXs), Environmental Assessments, and Environmental Impact Statements.

The aspects that must be considered when scoping and preparing documentation for a proposed project include archaeological sites, wetlands, floodplains, sensitive species, and critical habitats. If any extraordinary circumstances are identified during project scoping, a range of options for the project must be developed and the impacts of those options evaluated.

In CY99, SLAC submitted one CX, which was for a General Plant Project. It was for the Research Office Building, to be constructed northeast of the Administration and Engineering Building, and was approved by DOE/OAK as submitted.

\subsubsection{California Environmental Q uality Act}

NEPA compliance is considered to be the functional equivalent of compliance with the California Environmental Quality Act (CEQA). In support of this approach, the SMC Planning and Building Division (PBD) sent a letter dated November 4, 1999 to SLAC. The letter stated that PBD had elected not to exercise its CEQA and permitting authority for SLAC projects involving (for example) erosion control.

In CY99, SLAC submitted only one CX, which was for a new Research Office Building to be constructed northeast of the existing Administration and Engineering (A\&E) Building. This CX was approved by DOE/OAK. 


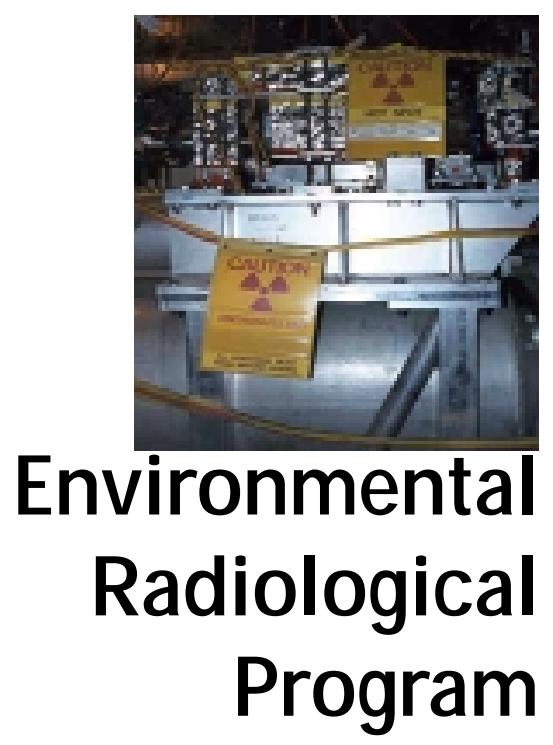

\subsection{Airborne Monitoring}

Airborne radionuclides are produced in the air volume surrounding major electron beam absorbers such as beam dumps, collimators, and targets. The degree of activation is dependent upon the beam power absorbed and the composition of the parent elements. The composition of air is well known, consisting of nitrogen, oxygen, and trace quantities of carbon dioxide and argon.

Induced radioactivity produced at high energies is composed of short-lived radionuclides, such as oxygen-15 $\left({ }^{15} \mathrm{O}\right)$ and carbon- $11\left({ }^{11} \mathrm{C}\right)$, with half-lives of 2 minutes and 20 minutes, respectively. Nitrogen-13 $\left({ }^{13} \mathrm{~N}\right)$, with a half-life of 10 minutes, is also produced, but in much lower concentrations. As a consequence of water cooling and concrete shielding, both containing large quantities of hydrogen, the thermal neutron reaction with stable argon produces argon- $41\left({ }^{41} \mathrm{Ar}\right)$, which has a half-life of 1.8 hours.

Calendar year (CY99) was an active year at the Stanford Linear Accelerator Center (SLAC). Many of the facilities at SLAC were powered up at least once during the year. Although each facility was running at dramatically different energies and durations, each had the potential to produce activated airborne radionuclides. Most facilities at SLAC had no uncontrolled venting of the accelerator housing during time of beam acceleration in CY99. There are two facilities at SLAC that are not totally enclosed, so emissions due to diffusion can occur.

For most of the facilities at SLAC, activated air is not released to the environment until the facility is opened for personnel entry. For the purpose of maintaining radiation doses to personnel as low as reasonably achievable, entries are administratively controlled to allow some time for short-half-life radionuclides to decay prior to entry. Cool-down periods are facility- and energy-dependent, varying from 30 to 60 minutes in CY99, with the norm being 60 minutes.

Of all the SLAC facilities, only End Station A (ESA) and the $B$ Factory, hereinafter referred to as PEP-II, have the potential to allow diffuse emissions of activated airborne products. Diffusion from ESA and PEP-II activities are via Beam Dump East (BDE) and Interaction Region 10 (IR-10), respectively. 
The majority of experimental facilities at SLAC are designed to transport the high-energy beams produced by the SLAC linac without high-energy losses, and thus without significant activation of the air within the facility. The accelerator, PEP-II, the Stanford Linear Collider (SLC), the Stanford Synchrotron Radiation Laboratory, and their experimental areas were designed to transport and condition (not absorb) high-energy electrons and positrons. In these structures the concentration of activated gases remaining after the "cool down" period were not measurable.

Those facilities that, by design or operation, involve losing or "dumping" high energy have the potential for producing activated airborne radionuclides. Beam-on time creates both energy loss and activation of the air surrounding the energy-loss area itself. In CY99, the following areas all experienced beam-on time:

- Beam Switchyard (BSY)

- Positron Source (PS)

- BDE at ESA

- Final Focus Test Beam

Energy-loss and beam-dump areas are sealed from access or venting, unless an emergency arises during operations or during beam-off until the required "cool-down" period has passed. The exceptions are BDE and IR-10 as noted earlier. Activation products are very short-lived (half-lives of only 2 minutes to 2 hours, inclusive), with decay during the cool down period resulting in non-measurable concentrations. In order to establish concentrations without measurable quantities, calculations were made using facility specifics. These calculations have been made using extremely conservative (protective of the public) assumptions.

As a government-owned contractor-operated facility, SLAC must, at a minimum, meet the requirements set by the Department of Energy (DOE). DOE Order 5400.5, Requirements for Radiation Protection for the Public, mandates that no individual in the general population be exposed to greater than $100 \mathrm{mrem}(1.0 \mathrm{mSv})$ in one year from all pathways due to DOE-funded activity. This Order prescribes calculations to be made to ensure that off-site releases to the public are below $100 \mathrm{mrem}$. The results of these calculations are called Derived Concentration Guides (DCGs).

A number of assumptions must be made in order to make the DCG calculations; SLAC has chosen the most conservative assumptions to err on the side of public safety. As an example of conservatism, SLAC has assumed that a member of the public would be wholly immersed in these activated gases while being off-site. Although it is obvious that this scenario is unrealistic, it allows the calculations to be made without the need to define the real scenario, and provides a wide margin of protection to the public. The DCGs, as calculated for SLAC's potential release of activated radioactive gases $\left({ }^{15} \mathrm{O},{ }^{11} \mathrm{C},{ }^{13} \mathrm{~N}\right.$, and $\left.{ }^{41} \mathrm{Ar}\right)$ are presented in Table $4-1$.

Table 4-1 Radioactive Gases Released to Atmosphere

\begin{tabular}{|c|c|c|}
\hline Radionuclide & Half-Life & DCG $\boldsymbol{\mu C} \mathbf{i} / \mathbf{c m}^{\mathbf{3}} \mathbf{a , b}$ \\
\hline \hline${ }^{15} \mathrm{O}$ & 2.1 minutes & $1.7 \times 10^{-9}$ \\
\hline${ }^{13} \mathrm{~N}$ & 9.9 minutes & $1.7 \times 10^{-9}$ \\
\hline${ }^{11} \mathrm{C}$ & 20.5 minutes & $1.7 \times 10^{-9}$ \\
\hline${ }^{41} \mathrm{Ar}$ & 1.8 hours & $1.7 \times 10^{-9}$ \\
\hline
\end{tabular}

${ }^{\mathrm{a}} \mu \mathrm{Ci}=3.7 \times 10^{4} \mathrm{~Bq}$

b Calculated from DOE Order 5400.5, assuming total submersion by dividing the averaged DCG by 10 . See Appendix A 
This same Order requires that DOE-funded activities comply with U.S. Environmental Protection Agency (EPA) requirements. Under EPA National Emission Standards for Hazardous Air Pollutants (NESHAP) Title 40 Code of Federal Regulations, Part 61 (40CFR61), SLAC must meet the requirements of this subpart by calculation of potential doses to both the maximally exposed individual and the public as a whole due to the emissions of airborne radionuclides. Continuous monitoring is not required because all of SLAC's emissions points are defined by EPA as "minor sources" of air pollution.

NESHAP emissions were derived using calculations based, again, on conservative assumptions. It was assumed that each time a beam-off situation occurred at any facility that the containment was breached by entry. If there was never a venting or breach, then the activated gases would decay to background and no emissions would result. In 20 hours time after beam-off, all activated gases would be less than $1 \%$ of their saturation values.

These emissions were derived by calculating the saturation activity for the radionuclides listed in Table 4-1, and then hypothetically releasing them instantaneously after the cool-down period. For both the IR-10 and BDE release points (which are not totally contained) a diffusion mechanism was conservatively estimated to determine releases that occurred continuously during beam-on periods.

SLAC demonstrates its fulfillment of NESHAP requirements of off-site dose to the public of less than $10 \mathrm{mrem}$. Fulfillment of this requirement is evident in the results of running the DOE-approved modeling program CAP88PC ${ }^{1}$, Version 1.0 (refer to Table 4-2, and Appendix B of this report).

\section{Table 4-2 Summary of Annual Effective Dose Equivalents D ue to 1999 Laboratory O perations}

\begin{tabular}{|c|c|c|c|c|}
\hline & $\begin{array}{l}\text { Maximum D ose } \\
\text { to G eneral } \\
\text { Public }^{a}, b \\
\text { (direct } \\
\text { radiation only) }\end{array}$ & $\begin{array}{l}\text { Maximum D ose } \\
\text { to G eneral } \\
\text { Public }{ }^{a, b} \\
\text { (airborne } \\
\text { radiation) }\end{array}$ & $\begin{array}{l}\text { Maximum Dose } \\
\text { to G eneral } \\
\text { Public }{ }^{a, b} \\
\text { (airborne + direct } \\
\text { radiation) }\end{array}$ & $\begin{array}{l}\text { Collective Dose } \\
\text { to Population } \\
\text { within } 80 \mathrm{~km} \text { of } \\
\text { SLAC }\end{array}$ \\
\hline Dose & 4.45 mrem & 0.03 mrem & 4.48 mrem & 17.42 person-rem \\
\hline $\begin{array}{l}\text { DOE Radiation Protection } \\
\text { Standard }\end{array}$ & $100 \mathrm{mrem}$ & 10 mrem & 100 mrem & - \\
\hline $\begin{array}{l}\text { Percentage of Radiation Pro- } \\
\text { tection Standard }\end{array}$ & $4.45 \%$ & $0.3 \%$ & $4.48 \%$ & - \\
\hline Background & 100 mrem & 200 mrem & 300 mrem & $\begin{array}{c}1.47 \times 10^{6} \text { person- } \\
\text { rem }\end{array}$ \\
\hline Percentage of Background & $4.45 \%$ & $<1 \%$ & $1.5 \%$ & Negligible \\
\hline
\end{tabular}

a This is the dose to the maximally exposed member of the general public. It assumes that the hypothetical individual is at the closest location to the facility continuously, 24 hours/day, 365 days/year.

b $100 \mathrm{mrem}=1 \mathrm{mSv}$ and 1 person-rem $=0.01$ person-Sv.

1 CAP88PC is a personal computer software system used for calculating both dose and risk from radionuclide emissions to air. 
The results of this modeling show that the maximum off-site dose, with all the conservative assumptions applied, from potential airborne emissions from SLAC is only $3 \times 10^{-2} \mathrm{mrem}$ $\left(3 \times 10^{-4} \mathrm{mSv}\right)$ annual effective dose equivalent (EDE). Thus, the public dose due to SLAC research is approximately 100 times lower than EPAs level of concern (10 mrem EDE).

\subsection{Wastewater Monitoring}

During CY99, wastewater containing small quantities of radioactivity within regulatory limits was periodically discharged to the sanitary sewers from the site. The only possible sources of liquid radioactive effluents were from low conductivity water (LCW) cooling systems in the BSY and certain other areas of the accelerator housing. Periodic system maintenance or leaks necessitate the disposal of LCW. In the case of leaking cooling systems, water is collected in sumps of sufficient size to hold the entire volume of LCW in the system. Along the Klystron Gallery, there are a series of polyethylene tanks that are used to hold LCW from the LINAC sumps and alcoves of the gallery prior to disposal.

The greatest sources of induced radioactivity were where the electron/positron beam was absorbed. The only significant radionuclides produced in water were the short-lived oxygen-15 $\left({ }^{15} \mathrm{O}\right)$ and carbon-11 $\left({ }^{11} \mathrm{C}\right)$; beryllium-7 $\left({ }^{7} \mathrm{Be}\right)$, with a half-life of 54 days; and longer-lived tritium $\left({ }^{3} \mathrm{H}\right)$, with a half-life of 12.3 years. Other radionuclides, which could potentially be in the water systems, would come from the activation of corrosion products in the water.

The activated corrosion products were typically gamma emitters. Oxygen-15 and ${ }^{11} \mathrm{C}$ are too shortlived to present an environmental problem in water. Beryllium-7 and corrosion products were removed from the LCW by the resin beds required to maintain the electrical conductivity of the water at a low level. Therefore, tritium was the only radioactive element present in the water that was of environmental significance in CY99. Tritium emits a weak beta particle which is detected primarily though liquid scintillation analysis.

As in previous years, SLAC discharged many batches of LCW to the sanitary sewer. All water potentially containing radioactivity was sampled and analyzed. All batches, as well as the cumulative total for the year, had contaminant levels that were within applicable radiological regulatory limits.

A summary of radioanalysis records of the wastewater discharged for each quarter of CY 99 is given in Table 4-3. A total of 1,486,000 gallons of LCW was discharged to the sanitary sewer during CY99. The total amount of tritium discharged was 7.11 millicuries.

Table 4-3 Radioanalysis Results for Wastewater D ischarged D uring CY99

\begin{tabular}{|c|c|c|}
\hline Period Released & Q uantity [gal ${ }^{\mathbf{a}}$ ] & Radioactivity [mCi $^{\mathbf{b}}$ ] \\
\hline \hline First Quarter & 377,000 & 2.1 \\
\hline Second Quarter & 361,000 & 4.7 \\
\hline Third Quarter & 421,000 & 0.3 \\
\hline Fourth Quarter & 327,000 & 0.01 \\
\hline Total: & $1,486,000$ & 7.11 \\
\hline a $1 \mathrm{gal}=3.8$ liter & \\
b $1 \mathrm{mCi}=3.7 \times 10^{7} \mathrm{~Bq}$ &
\end{tabular}


SLAC is also bound by the provisions in a contract for service with the West Bay Sanitary District, Permit No. WB970401-F and Title 10 Code of Federal Regulations,(10CFR), Part 20, Section 2003 (10CFR20.2003). These provision limited SLAC to a maximum of $5,000 \mathrm{mCi}$ (that is $5 \mathrm{Ci}$, or $1.85 \times 10^{11} \mathrm{~Bq}$ ) of all radionuclides to be discharged to the sanitary sewer each calendar year.

The concentration of radioactivity released was, in all cases, less than the DCG specified by DOE Order 5400.5. The total tritium activity released in CY99 was less than $1 \%$ of the annual limit. The history of radioactivity discharged from the SLAC site is shown in Table 4-4.

Table 4-4 History of Radioactivity Discharged

\begin{tabular}{|c|c|c|}
\hline Year & Q uantity [gal ${ }^{\mathbf{a}}$ ] & Radioactivity $\left[\mathbf{m C i}^{\mathbf{b}}\right.$ ] \\
\hline \hline 1992 & 123,000 & 40.6 \\
\hline 1993 & 193,618 & 2.51 \\
\hline 1994 & 219,875 & 1.71 \\
\hline 1995 & 307,887 & 10.8 \\
\hline 1996 & 313,427 & 338.8 \\
\hline 1997 & 298,977 & 22.3 \\
\hline 1998 & $1,502,000$ & 71.8 \\
\hline 1999 & $1,486,000$ & 7.11 \\
\hline
\end{tabular}

a $1 \mathrm{gal}=3.8$ liter

b $1 \mathrm{mCi}=3.7 \times 10^{7} \mathrm{~Bq}$

\subsection{Stormwater Monitoring}

Samples of stormwater, as described in Section 3.3.3, were analyzed for radioactivity. The results of these analyses showed no detectable levels of tritium or other radioactivity.

\subsection{G roundwater}

Tritium analyses were conducted on groundwater from Existing Well 4 (EXW-4), Monitoring Well 30 (MW-30), and all other SLAC monitoring wells sampled in CY99. These wells are described in Section 5 of this document. As in past years, tritium was detected at low levels in EXW-4 and MW30. The concentrations of tritium in samples from EXW-4 and MW-30 were 10,000 picocuries per liter $(\mathrm{pCi} / \mathrm{L})$ and $700 \mathrm{pCi} / \mathrm{L}$ respectively. Both of these concentrations are well below the maximum allowable concentration of tritium in drinking water of 20,000 pCi/L set by the United States Environmental Protection Agency and adopted by the State of California. However, groundwater at SLAC is not usable as drinking water due to a very high total dissolved solids (TDS) content, and it is not used for any other purpose. Tritium was not detected in any monitoring wells other than those listed above.

\subsection{Radiological Media Sampling Program}

Media sampling was limited to industrial wastewater (the major pathway for radionuclide release to the environment) and stormwater. Future media samples will be defined by the SLAC Radiological Environmental Monitoring Program which is under development. The low source terms proportionate to DOE's DCGs have identified only this route as a likely pathway for any potential off-site population exposure. 


\subsection{Soil Sampling}

Soil sampling in the past has been performed when activities in the accelerator area suggested that it would be prudent, such as construction inside the accelerator enclosure. The soil samples were analyzed for gamma-emitting radionuclides with a high-purity germanium detector. Environmental soil sampling will be part of the Radiological Environmental Surveillance Program which is being developed under SLAC's Radiological Environmental Monitoring Plan.

Soil from the area north of accelerator Sector 13, formerly used to store radioactive accelerator components, was one such area sampled in CY99. The analysis revealed the presence of the radionuclides ${ }^{137} \mathrm{Cs},{ }^{60} \mathrm{Co}$, and ${ }^{133} \mathrm{Ba}$ in concentrations of $.2 \mathrm{pCi} / \mathrm{gram}, .2 \mathrm{pCi} / \mathrm{gram}$ and $.3 \mathrm{pCi} / \mathrm{gram}$, respectively. Also present were the naturally occurring radionuclides ${ }^{40} \mathrm{~K}$, in concentrations ranging from 3 to $16 \mathrm{pCi} / \mathrm{gram}$, and those of the uranium and thorium chains.

The concentration of ${ }^{137} \mathrm{Cs}$ is consistent with average concentrations of fallout from weapons testing during the 1950's and 1960's. The low concentrations of ${ }^{60} \mathrm{Co}$, found only in localized areas, suggests that its presence was the result of corroding metal articles stored there. These extremely low radioactivity levels pose no threat to personnel or the environment. Further surveys are being done to ensure that all radioactive material has been removed from the area.

\subsection{Passive Thermoluminescent D osimeter Monitoring Program}

SLAC has a site boundary environmental Thermoluminescent Dosimeter (TLD) monitoring program. Landauer, a National Voluntary Laboratory Accreditation Program certified dosimetry service, was contracted to provide SLAC with quarterly TLDs. The LDR-X9 aluminum oxide TLD was designed to measure low-level photon radiation with a minimum detection level of $0.02 \mathrm{mrem}$ $(0.0002 \mathrm{mSv})$. The LDR-I9 TLD is used for monitoring neutron radiation with a minimum detection level of $10 \mathrm{mrem}(0.1 \mathrm{mSv})$. Both of these TLD systems were in use throughout CY99.

The environmental measurements using TLDs are summarized in Appendix D. Figures D-1 through D-3 in Appendix D depict the locations of these TLDs. TLD results indicated that the site boundary location with the highest accumulated dose-equivalent in CY99 reported $30.3 \mathrm{mrem}(0.303 \mathrm{mSv})$ above background.

The TLD data for CY99 were used to evaluate the radiation dose from direct radiation to the maximally exposed member of the general public and the collective dose to the general public within 80 km of SLAC. See Table 4-2 for a summary of the results and Appendix D for data.

\subsection{Low-Level Radioactive Waste Reduction}

The quantities of low-level radioactive wastes on site were the accumulation of waste generated over years of SLAC's operation. A significant portion of SLAC's low-level radioactive waste is in the form of scrap metals.

Depending on their condition and the radiological characteristics, some of the metals may be recycled because radioactive levels are very low and are candidates for regulatory exemption. This waste reduction approach is called Return-on-Investment (ROI). ROI is a DOE-sponsored pollution prevention activity that assists sites in recycling or reuse of materials or waste that contain residual radioactive material. ROI activities were moved forward in CY99. 
SLAC has found that simple things have had a marked effect on day-to-day production of radioactive waste. Better housekeeping in CY99 of accelerator areas reduced the amount of material (parts, equipment, tools, and supplies) that must be considered potentially activated when removed from high-radiation and beam-loss areas.

Here again, a concern for reduction of radioactive waste has led to a more comprehensive approach in both characterization and management of activated material that could become waste. It was found that simple disassembly of parts and equipment, where only certain material was activated, resulted in a significant reduction of waste needing to be managed as being radioactive, a process known as volume reduction. See Section 2 for performance measures for waste reduction goals. 


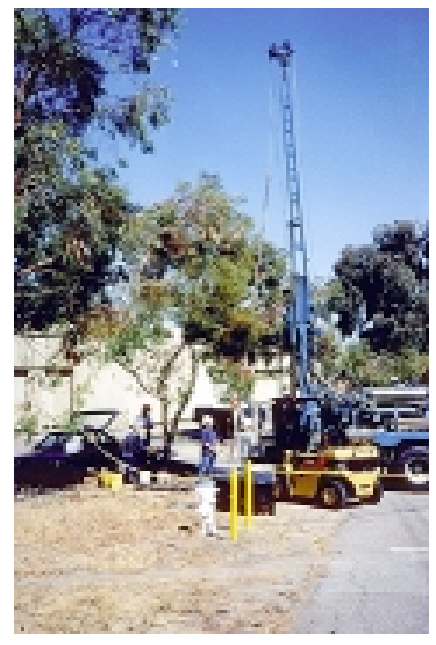

\section{G roundwater Protection and Restoration}

The Stanford Linear Accelerator Center (SLAC) performs groundwater protection through monitoring of a network of wells located for environmental surveillance as well as through investigations of contaminated soil and groundwater impacted with chemicals of concern, both radiological and non-radiological, to ensure protection of human health and the environment. Documents such as Standard Operating Procedures for Environmental Protection and Restoration, a Quality Assurance Project Plan, and a Health and Safety Plan support monitoring and investigation activities.

The Annual Well Inspection and Maintenance Manual guides inspection of wells to protect the integrity of the monitoring wells. In calendar year 1999 (CY99), groundwater monitoring data were collected on a semi-annual schedule from existing wells and from new wells as they were installed for investigative work. All reports and documents referred to in this section are available at the SLAC library, or can be obtained from the Environmental Protection and Restoration (EPR) Department at SLAC. To support this work, SLAC provides documentation of the groundwater regime with respect to quantity and quality.

\subsection{Documentation}

The groundwater regime at the SLAC facility and nearby off-site areas has been comprehensively documented in the SLAC Hydrogeologic Review completed in CY94. This report compiled data and summarized results of the numerous geologic, hydrogeologic, and hydrogeochemical investigations that have taken place at or near SLAC for various reasons:

- Water resources studies

- Research

- Geotechnical studies (used to site the structures being built at SLAC)

- Environmental and monitoring purposes 
The report developed a conceptual model of the groundwater regime at SLAC. Of particular interest to studies of contaminant transport was the fact that the major bedrock unit underlying SLAC conveyed groundwater primarily by fracture flow. Based on numerous tests in exploratory borings and wells, the hydraulic conductivity of this bedrock was much less than the range of hydraulic conductivity generally accepted as representing natural aquifer material.

A Beneficial Use Assessment, which included a well survey of the area around SLAC, provided information on possible beneficial uses of groundwater at SLAC, as outlined in the California Regional Water Quality Control Board Basin Plan. This report concluded that because groundwater at SLAC has a very high Total Dissolved Solids (TDS) content (as high as 10,000 milligrams per liter) and a very low rate of flow, it is not suitable for most potential beneficial uses. An updated survey for wells that have a potential beneficial use in proximity to SLAC was completed in CY99 as part of the site characterization of the Former Solvent Underground Storage Tank (FSUST) Area. No new wells were identified in the updates.

\subsection{Identification and Summary of Potentially Contaminated Areas}

The SLAC 1992 report entitled Identification and Summary of Potentially Contaminated Sites provides a summary of areas that may be contaminated by hazardous substances. Information for the report was collected from a variety of sources including spill reports, aerial photographs, operations records, reports on previous investigations, and interviews with SLAC personnel throughout the facility. As other potentially contaminated areas are identified, they are incorporated into a master list. As funds are available and as the areas become accessible, they are put in a workplan for evaluation. Several areas were evaluated in CY99. Reports will be generated for this work in CY00.

\subsection{Strategies for Controlling Sources of Contaminants}

Strategies for contaminant source control involve measures to control known soil or groundwater contamination, and procedures to address practices that may contribute to soil and groundwater contamination. In addition, the Stormwater Pollution Prevention Plan and the Spill Prevention, Control, and Countermeasure Plan discuss best management practices for preventing contamination at the SLAC facility. Environment, Safety, and Health Manual chapters on Secondary Containment and Oil-filled Equipment Management Programs address practices for preventing contamination from reaching soil or groundwater.

To reduce the threat of groundwater contamination further, SLAC has established Waste Minimization and Pollution Prevention Awareness programs. These programs have promoted source control through the reduction of hazardous material usage and hazardous waste generation. This was accomplished by encouraging environmentally conscious engineering and by increasing employee awareness. 


\subsection{Restoration Activities}

SLAC first began to develop a comprehensive Environmental Restoration Program (ERP) in CY91. The program delineates how SLAC will address environmental contamination problems from discovery and characterization through remediation and long-term monitoring or maintenance, if required. The restoration approach at SLAC is as follows:

1. Identify sites with actual or potential contamination (involving soil, groundwater, surface water, and/or air)

2. Prioritize contaminated sites based on site complexity, nature of contamination, associated risks, remaining data needs, and projected remedy

3. Perform investigations and identify remedies protective of human health and the environment, beginning with the highest-priority sites

SLAC is generally at step 3 above. Investigative work this past year has proceeded for contaminated groundwater sites which are discussed in this section. SLAC personnel continued to be actively involved in various public participation activities throughout CY99. In particular, SLAC participated in the Coordinated Resource Management and Planning process CRMP process, a watershed management group for San Francisquito Creek.

SLAC follows general Comprehensive Environmental Response, Compensation, and Liability Act (CERCLA) technical guidance in investigating and remediating soil and groundwater contamination. SLAC is not, however, listed in the National Priorities List as a Superfund site and is not required to follow formal CERCLA procedures. The California Regional Water Quality Control Board (RWQCB) provides oversight and approval of restoration activities that impact surface or groundwater at SLAC. The San Mateo Department of Health Services (the county) conducts oversight of environmental restoration activities involving remediation of contaminated soil.

In CY99, SLAC's ERP continued investigation for site characterization and evaluation of remedial alternatives. Four groundwater sites have been identified and are being monitored (see Figures 5-2 and 5-3, pages 59 and 60). One of these sites is monitored on a semiannual basis under state RWQCB Waste Discharge Order No. 85-88. Confirmation of an additional fifth groundwater site (located in the lower salvage yard) will be completed in CY00.

Investigation and remediation of sites impacted with Polychlorinated Biphenyls (PCBs) continued in CY99. Removal actions have taken place at a number of former transformer sites and at the active Master Substation. The final report documenting the removal action at the Master Substation was completed in CY99 and submitted to the U.S. Environmental Protection Agency, the RWQCB and the county.

A community relations plan was completed and distributed to the surrounding community in CY93. SLAC community relations activities currently center on the monthly meetings of the Steering Committee for the CRMP process for the San Francisquito Creek watershed. 


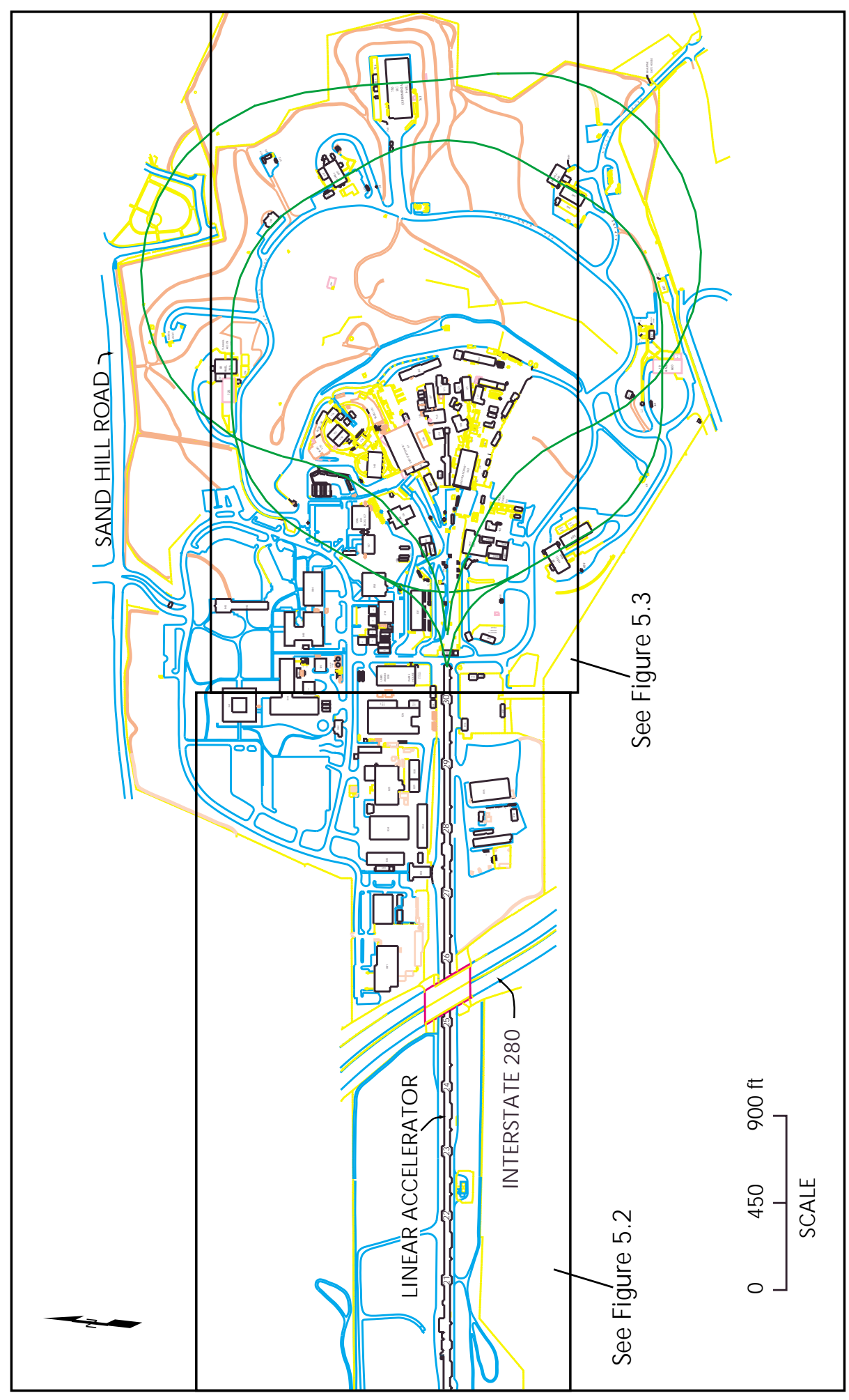

Figure 5-1 Site Map 


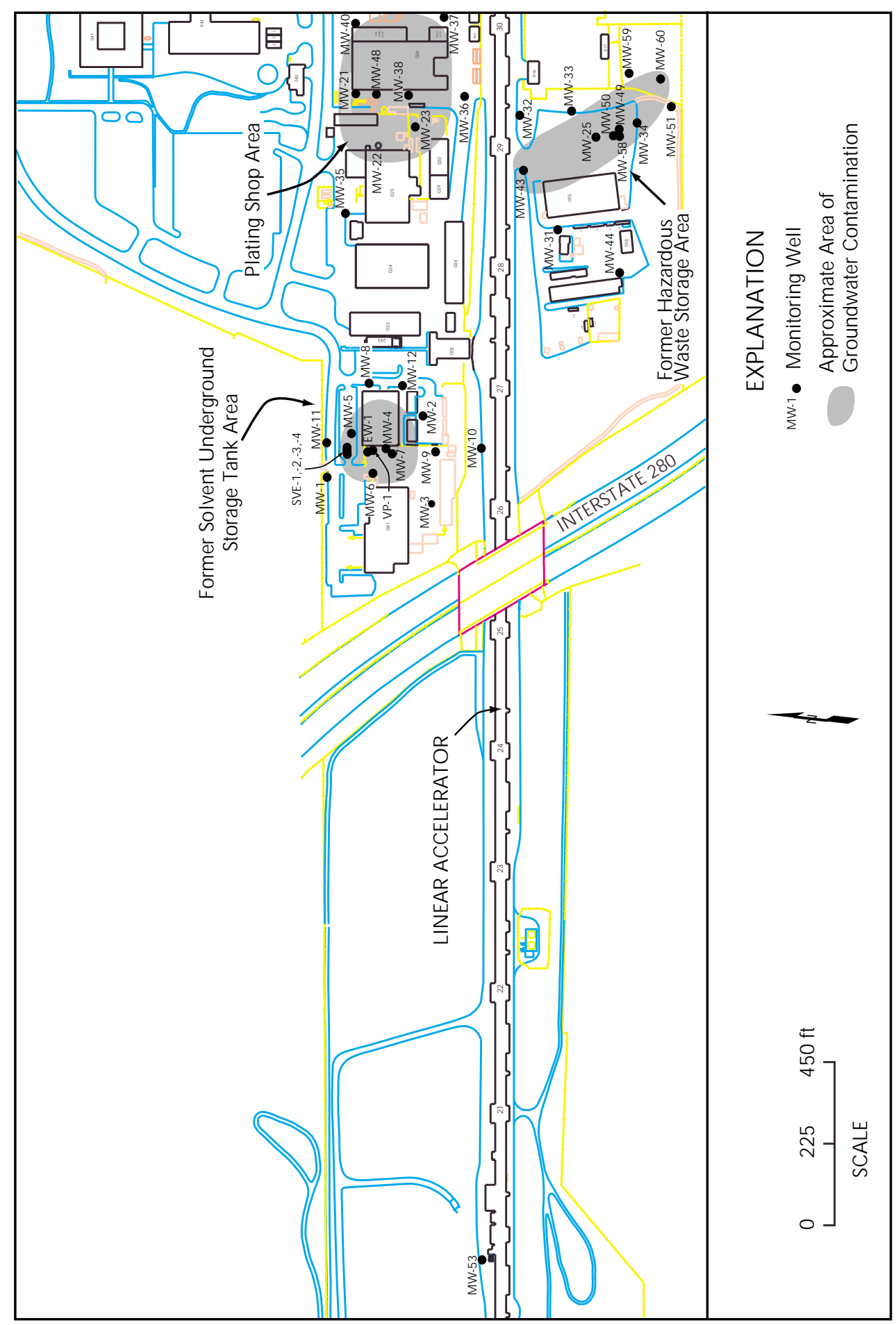

Figure 5-2 Location of Western G roundwater Monitoring Well Network and Areas with Groundwater Contamination 


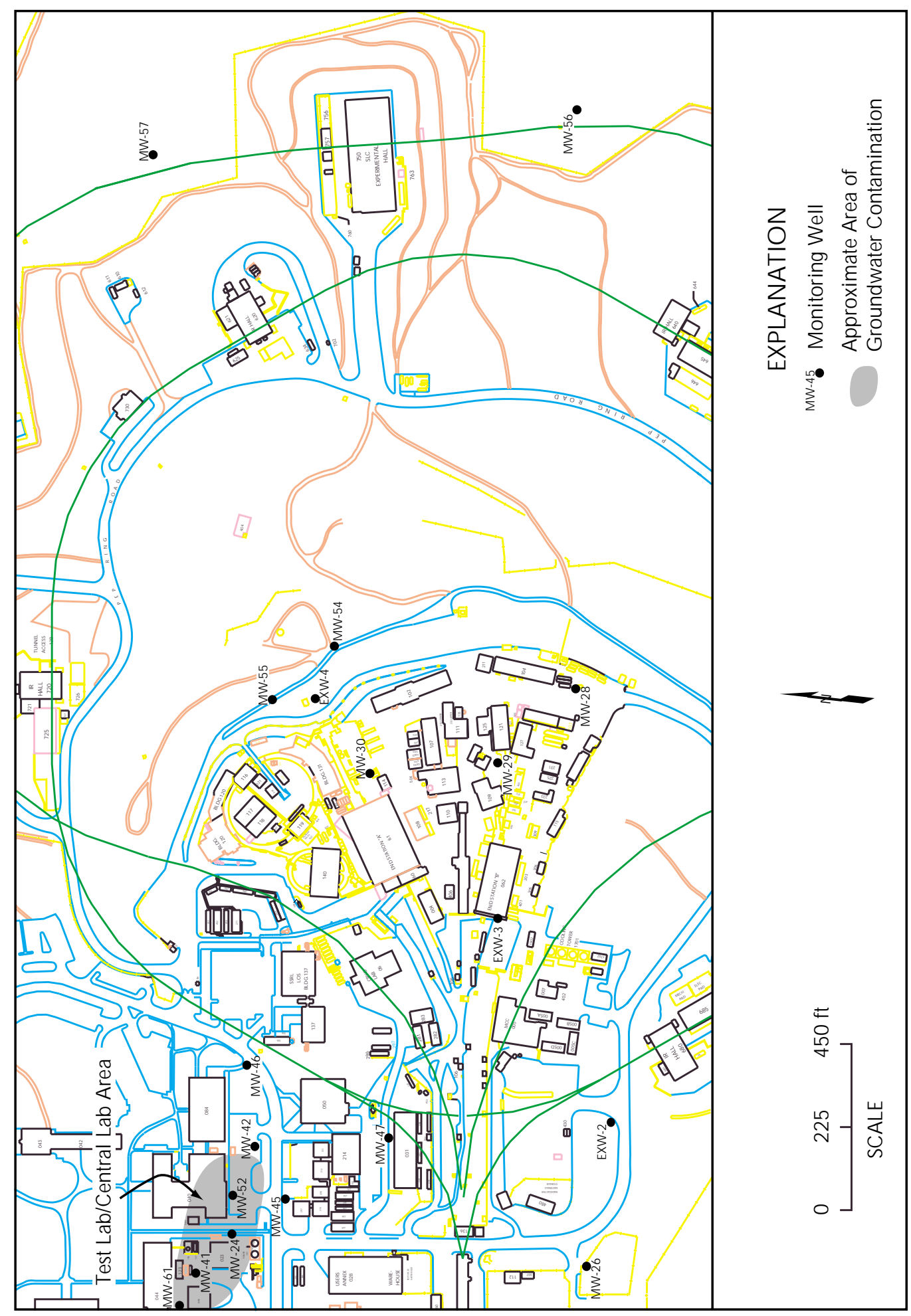

Figure 5-3 Location of Eastern G roundwater Monitoring Well N etwork and Areas with Groundwater Contamination 


\subsection{G roundwater Characterization Monitoring Network}

\subsubsection{CY99 Summary of Results and Issues}

Work continued in CY99 on putting in more wells around the four areas of known contamination to define the lateral and vertical extent of potential contamination. The draft report of the site characterization for the Test Lab/Central Lab was completed in CY99. The report, which is described below, was submitted to the State of California RWQCB for review and comment.

Groundwater samples were collected from 46 wells in CY99 and analyzed for a variety of constituents including volatile organic compounds (VOCs). Figure 5-1 on page 58 shows the portion of the site that contains the monitoring network. Figures 5-2 on page 59 and 5-3 on page 60 show the specific well locations. The groundwater analytical results were generally within each well's historic range of concentrations.

\subsubsection{Background}

SLAC characterizes groundwater at the site in order to determine and document the effects that the facility operations have had on groundwater quality. The groundwater monitoring network includes 13 wells which provide environmental surveillance of groundwater conditions. They are used to monitor general groundwater quality in the major areas of the facility that historically or presently store, handle, or use chemicals which may pose a threat to groundwater quality. In addition, the groundwater monitoring network at SLAC includes 47 wells that check groundwater at four distinct sites with known ground water contamination.

During ongoing remedial investigations, selected wells at areas with known groundwater contamination are sampled and analyzed on a semi-annual basis. Samples may be analyzed for one or more of the following:

- Volatile Organic Compounds and Semi-Volatile Organic Compounds

- Total Petroleum Hydrocarbons

- Metals

- Polychlorinated Biphenyls (PCBs)

- Total Dissolved Solids (TDS)

- General minerals

- Tritium

VOCs have been detected at levels of concern at SLAC. The results of semi-annual sampling and analysis of wells are reported to the RWQCB in semi-annual monitoring reports.

Table 5-1 on page 62 summarizes the wells at SLAC by the number of wells, area of the facility, and the purpose of the well. The purpose of the well may be either monitoring plumes with chemicals of concern or environmental surveillance, including general background monitoring. One well was installed at SLAC in CY99. As noted in Table 5-1, the four areas with groundwater contamination are:

- The Former Hazardous Waste Storage Area (FHWSA).

- FSUST.

- The Test Lab and Central Lab areas.

- The area of the Plating Shop. 
In addition, a grab groundwater sample taken at the Lower Salvage Yard during excavation of soil impacted with PCBs detected PCBs in a groundwater sample.

Wells will be installed in this area in CY00.

Table 5-1 Purpose and Location of Monitoring Wells

\begin{tabular}{|l|c|c|}
\hline & N umber of Active Wells \\
\hline Area of Site & $\begin{array}{c}\text { Monitoring Plumes with } \\
\text { Chemicals of Concern }\end{array}$ & Environmental Surveillance \\
\hline \hline FSUST $^{\mathrm{a}}$ & 18 wells & \\
\hline FHWSA $^{\mathrm{b}}$ & 12 wells & \\
\hline Test Lab/Central Lab & 7 wells & \\
\hline Plating Shop & 9 wells & 3 wells \\
\hline Research Yard & & 3 wells \\
\hline Beam Dump East & & 1 well \\
\hline $\begin{array}{l}\text { Master Substation; } \\
\text { Lower Salvage Yard }\end{array}$ & & 1 well \\
\hline CHWMA & & 1 well \\
\hline End Station B & & 4 wells \\
\hline Vacuum Assembly Building & & \\
\hline Other (remote area) & & \\
\hline
\end{tabular}

a Former Solvent Underground Storage Tank

b Former Hazardous Waste Storage Area

c Central Hazardous Waste Management Area

The locations with chemicals of concern in groundwater are shown in Figure 5-2 on page 59 and in Figure 5-3 on page 60. Except for the Lower Salvage yard, the main organic chemical in all of these areas is trichloroethene (TCE) and its breakdown products. TCE was historically used at SLAC as a cleaning solvent. TCE is no longer in general use at SLAC. It is used in very small quantities in a few research laboratories. The four groundwater sites impacted with chemicals of concern are discussed in detail in the next section. This is followed by a discussion of PCB impacted soil sites.

\subsection{G roundwater Site D escriptions and Results}

\subsubsection{Former Solvent U nderground Storage Tank}

\subsubsection{Background}

A groundwater monitoring network is located in proximity to the SLAC Plant Maintenance building in the northwestern portion of the facility (see Figure 5-2 on page 59). This network consists of eighteen wells which are being used to monitor the migration of chemical constituents associated with the FSUST. The tank was used to store organic solvents during the period of 1967 to 1978. A pressure test performed on the FSUST in 1983 indicated a leak. The tank and accessible contaminated soil were removed in December 1983. 
The California RWQCB requires that SLAC monitor selected wells at the FSUST site on a semi-annual basis (RWQCB Waste Discharge Order 85-88). Since 1987, the samples have been analyzed for VOCs (Environmental Protection Agency Methods 8010/8020) by an analytical laboratory certified by the California Department of Health Services.

\subsubsection{CY98/99 Results and Issues}

The results of investigations performed at the FSUST were provided in two draft reports, the Site Characterization for the Former Solvent Underground Storage Tank Area, and the Evaluation of Remedial Alternatives for the Former Solvent Underground Storage Tank Area. The Site Characterization report described the nature and extent of chemicals in the soil and groundwater at this site and evaluated the risks posed by these chemicals. The evaluation of the risks was used to identify remedial goals. The Evaluation of Remedial Alternatives report established remedial action objectives and then evaluated 42 alternatives in order to determine which would meet best the objectives. Comments were received from the California RWQCB. The final reports are expected to be completed in CY00.

A Remedial Action Plan describing plans for the agreed action will be prepared in CY00. The proposed plan includes installing a pump and treat system with the goal of containing the entire groundwater plume. A study was instigated to evaluate the feasibility of bioremediation to enhance groundwater cleanup. Further evaluation of bioremediation will be conducted in CY00.

\subsubsection{Former Hazardous Waste Storage Area}

\subsubsection{Background}

The FHWSA was in use from approximately 1965 to 1982 . During closure of the yard, PCBs were found in shallow soils. As a result, several inches of topsoil were removed. Monitoring well 25 (MW-25) was installed in this area in 1990, and VOCs were detected in the groundwater. Three wells were installed in CY98, in addition to the nine wells previously installed at this site. Figure 5-2 on page 59 defines the extent of VOCs in groundwater.

Results of the CY98 drilling and testing program delineated the extent of groundwater impacted with chemicals of concern to the southeast. Based on work performed in CY97, most of the impacted groundwater appears to be confined to the Santa Clara Formation which comprises the upper 20 feet of bedrock.

\subsubsection{CY99 Results and Issues}

Plans for further investigative work were conducted in CY99. Implementation of this plan will occur in CY00. 


\subsubsection{Plating Shop}

\subsubsection{Background}

In 1990, three monitoring wells, MW-21, MW-22, and MW-23, were installed downgradient of the Plating Shop. Constituents of concern were detected in all of the three wells and an investigation began as described below.

A concrete steam cleaning pad is located adjacent to the Plating Shop and work performed in CY97 identified the soil beneath it as a potential source of VOCs in the groundwater. Consequently, an Interim Removal Action was performed in CY98, which included removing the pad, and excavating approximately 200 cubic yards of contaminated soil for off-site disposal. A new steam cleaning pad was built to replace it at a location to the south of the original pad. In order to construct it at the new location, MW-22 had to be destroyed.

\subsubsection{CY99 Results and Issues}

Plans for further investigative work were conducted in CY99. Implementation of this plan will occur in CY00.

\subsubsection{Test Lab and Central Lab}

\subsubsection{Background}

Monitoring Well 24 was installed between the Test Lab and Central $\mathrm{Lab}$ in CY90 at the site of a former leaking diesel pump. Contaminated soil was removed and the well was installed to monitor for the possible presence of diesel fuel, which has never been detected in this well. Chlorinated solvents have been detected, A soil gas survey and soil borings were drilled to delineate the sources of contamination. Results of the investigation indicate three possible source areas including one adjacent to the Test laboratory and two adjacent to the Central Laboratory.

\subsubsection{CY99 Results and Issues}

Results of the investigative work at the Test Lab/ Central Lab area were detailed in the site characterization report for the Test Lab/Central Lab area. The report was submitted to the RWQCB for review and comment in late CY99. Based on the characterization studies and a risk assessment evaluating the potential risks to human health and the environment as minimal, the report proposes long term monitoring of the plume. The final report is expected to be completed in CY00.

\subsection{Soil Sites Description and Results}

\subsubsection{Lower Salvage Yard}

\subsubsection{Background}

The Lower Salvage Yard has historically been used for storage of salvaged equipment, including oil-filled equipment and other materials such as scrap metal including lead. Prior to its use as a salvage yard, SLAC's first substation occupied the area. 
Site characterization data indicated several chemicals of concern including PCBs and petroleum hydrocarbons. Thus a removal action was initiated in CY99 as described below.

\subsubsection{CY99 Results and Issues}

A total of 3,114 tons of material were excavated from the Lower Salvage Yard to achieve the cleanup goal of 1 part per million PCBs. However, PCBs above the cleanup goal remain in the side walls of the excavation. Thus additional excavation will be required in the future. In addition, PCBs were detected in a groundwater sample from a deep part of the excavation. Two downgradient groundwater-monitoring wells will be installed in CY00 to identify whether chemicals have migrated in groundwater.

\subsubsection{IR-6 D rainage Channel and Research Yard Investigation and Remediation}

\subsubsection{Background}

In CY91, the first phase of an investigation was performed in two unlined drainage ditches located between IR- 6 and IR-8. PCB contamination was found in portions of the eastern ditch, the IR-6 Drainage Channel, originating on SLAC property and extending approximately 350 feet off-site onto adjacent undeveloped property owned by Stanford but once leased to a private party. SLAC constructed a fence to prevent uncontrolled access to this contaminated area.

In CY92, soil and sediment samples were taken along a 2.5 mile length of San Francisquito Creek and analyzed for a variety of constituents. The results showed no detectable PCBs. Lead analysis showed only background levels. However, sample analysis of the storm drain catch-basin sediments upstream of the contaminated areas in the Research Yard indicated both PCB and lead contamination.

Additional study of the drain system and removal and off-site disposal of contaminated sediments from the catch basins and the IR-6 off-site drainage channel occurred in CY95. The IR-6 Drainage Channel Engineering Evaluation and Cost Analysis was written in CY95 to establish clean-up standards based on risk analysis and to guide the removal action. The RWQCB as the lead agency reviewed the report.

In CY97, it was found that sediments with PCBs were still entering the IR-6 Drainage Channel. Video taping of the storm drain lines indicated sediment was trapped in the lines. This sediment in the storm drain lines was the presumed main source of residual PCB. In CY97, all removable solids were flushed out of the Research Yard drain lines.

\subsubsection{CY99 Results and Issues}

In CY99 extensive further evaluation of the Research Yard indicated several potential sources of PCBS in to the IR-6 Drainage Channel. These former transformer sites will be further investigated in CY00 and remediated if necessary. 
An urgent removal was performed in CY99 at one of these former transformer sites, the 1.0/1.5 Megawatt Power Supply Substation, due to concentrations as high as tens of thousands of parts per million of PCBs detected in surface sediment.

The work was completed in CY99 with involvement from the U.S. Environmental Protection Agency, Region 9, and the San Mateo County Department of Health Services. Approximately 38 tons of material was excavated. The rest of the substation will be characterized in more detail in CY00.

During the course of these studies, lead and PCBs were found in sediment that has accumulated on the asphalt near buildings and equipment in the Research Yard. Cleaning of this accumulated sediment in a given area and several downgradient catch basins occurred in CY99.

The cleaning consisted of vacuuming up accumulated sediment and debris and then pressure washing. The area will be retested in CY00 and if it has remained clean then other surficial areas of the Research Yard will be cleaned.

Samples were collected at a 50-foot interval down the length of the off-site IR-6 Drainage Channel. The concentrations are consistent with last year's monitoring results, which indicate that PCBs are only present in the upper reaches of the channel and have not migrated. Where present, PCBS are at or below last year's concentrations. Lead concentration in channel sediments are within background levels for this area.

\subsection{Q uality Assurance}

As described in the Quality Assurance Project Plan and the Standard Operating Procedures, SLAC conducts a data validation review for all data collected. 


\section{$\mathbf{A}$}

\section{Model for Potential D ose Assessment}

According to Department of Energy (DOE) Orders, an assessment of whole-body dose equivalent (in person-rem) to the general population near SLAC is required where appropriate. For this report, the term dose equivalent simply will be called dose. SLAC's dose to the maximally exposed member of the general public due to accelerator operations was conservatively estimated to be $4.48 \mathrm{mrem}(0.0048 \mathrm{mSv})$ in CY99 from penetrating radiation. The $4.48 \mathrm{mrem}(0.048 \mathrm{mSv})$ value is approximately $1.5 \%$ of the total natural background dose and is $4.48 \%$ of the dose limit for members of the general population, that is, $100 \mathrm{mrem}(1 \mathrm{mSv})$ per year (DOE Order 5400.5).

There are three major pathways leading to human exposure from human-made ionizing radiation:

- Airborne Radioactivity.

- Food Chain Radioactivity.

- Direct Exposure to Penetrating Radiation.

Of these three major pathways, only direct exposure to penetrating radiation is of any measurable significance from SLAC operations. The sources of this exposure are from neutrons resulting from the absorption of high-energy electrons, from photons from klystron operations, and/or from the experimental areas where energetic particles are created, some of which may escape from the heavily shielded enclosures.

In order to make an accurate and realistic assessment of radiation exposure to the public at low doses, it is necessary that exposure from the natural radiological environment be known, that is, background radiation. This is true because the instruments used respond to natural radiation sources as well as human-made sources, and the portion due to natural radiation must be subtracted from the total measurement. The population exposure assessments appearing in this report are in all cases overstatements, due to the conservative modeling assumptions used compared to the likely actual impact; hence, the resulting values are representative of an upper limit of the possible range.

While the annual radiation dose from accelerator operations at the site boundary has generally been measurable, it has always amounted to less than $10 \%$ of the total annual individual dose from natural background radiation. According to an Environmental Protection Agency (EPA) report, the average dose from cosmic, terrestrial, and internal radiation (not including radon) in California is $125 \mathrm{mrem}(1.25 \mathrm{mSv})$. For purposes of comparison, we have rounded this number down to $100 \mathrm{mrem}(1 \mathrm{mSv})$. 
Another quantity of interest is the population dose in units of person-rem (person-cSv). This is simply the product of average individual dose and the total population exposed. For example, if 1,000 people are exposed to an average annual background dose of $0.1 \mathrm{rem}(1 \mathrm{mSv})$, then the population dose is $0.1 \times 1,000$ or 100 person-rem (1 person-Sievert) from natural background radiation. The annual variation of exposure to natural background radiation may be $\pm 20 \%$, largely caused by differences in naturally occurring uranium, thorium, and potassium present in the ground and in building material where people live and work.

Most of the high energy accelerator laboratories have made measurements to determine the characteristic attenuation of radiation fields from their facilities. These measurements are unique to each facility because of design differences, types of machines, and surrounding topography. We have chosen a conservative formula for calculating the dose at distances other than the point of measurement. Lindenbaum gave a method for evaluating skyshine which was later verified by Ladu using Monte Carlo techniques. Lindenbaum approximated the falloff by $\left(e^{-R /} \lambda\right)\left(R^{-1}\right)$ where $R$ is distance in meters from the source and $\lambda=250 \mathrm{~m}$. This equation fits the SLAC data fairly well for neutron doses and is the one used to predict skyshine doses beyond our measuring stations (see Figure A-1). It is likely that the methods used and reported in this document could overestimate the true population dose by at least an additional factor of two. This model is used for photon skyshine as well as a conservative model for neutron.

In CY99, the doses to the public were dominated by photon radiation from either the klystrons or the accelerator with neutron doses being insignificant. The model used for evaluating the dose to the general public was as follows:

A. Maximally Exposed Member of the General Public:

1. Determined the closest locations of the general public to the facility.

2. Evaluated the thermoluminescent dosimeter (TLD) data closest to these locations.

3. Determined the source of the radiation as seen by the TLD station.

4. Extrapolated the photon dose from the source to the general public using a conservative line source geometry ( $1 / \mathrm{R}$ relationship), if the source was klystron radiation. In locations where the line source geometry may not have been accurate, it was conservative.

5. Extrapolated the neutron dose or photon dose from accelerator radiation using the Lindenbaum approximation.

6. Evaluated TLD data to determine the highest dose locations.

7. Determined the location of the general public closest to these TLD locations.

8. Extrapolated the photon dose from the source to the general public using a conservative line source geometry ( $1 / \mathrm{R}$ relationship), if the source was klystron radiation. In locations where the line source geometry may not have been accurate, it was conservative.

9. Extrapolated the neutron dose or photon dose from accelerator radiation using the Lindenbaum approximation.

10. Reported the highest dose to any member of the general public as the maximally exposed individual.

B. Collective Dose to the General Public:

1. Established a population grid out to $80 \mathrm{~km}$ from the facility.

2. Determined the highest site boundary TLD dose. 
3. Applied this dose conservatively to the whole facility.

4. Applied this dose to the population grid using a line source geometry ( $1 / \mathrm{R}$ relationship) out to 500 meters of the facility and a point source geometry (1/R $R^{2}$ relationship) from 501 meters to 80,000 meters.

5. Extrapolated the neutron dose using the Lindenbaum approximation.

6. Summed all the population doses from the grid.

The population demographics in the vicinity of SLAC, that is, within an $80 \mathrm{~km}$ radius, include a mixture of commercial and residential dwellings. Based on the data from the 1990 census, the population estimate in this area is about 4,917,443 residents. Based on the TLD results, the maximum dose at the SLAC site boundary was about $30.3 \mathrm{mrem}$ in CY99. Using this maximum dose value, it was estimated that the collective dose to the population within $80 \mathrm{~km}$ of SLAC was about 17.16 person-rem ( 0.1716 person-Sv). 


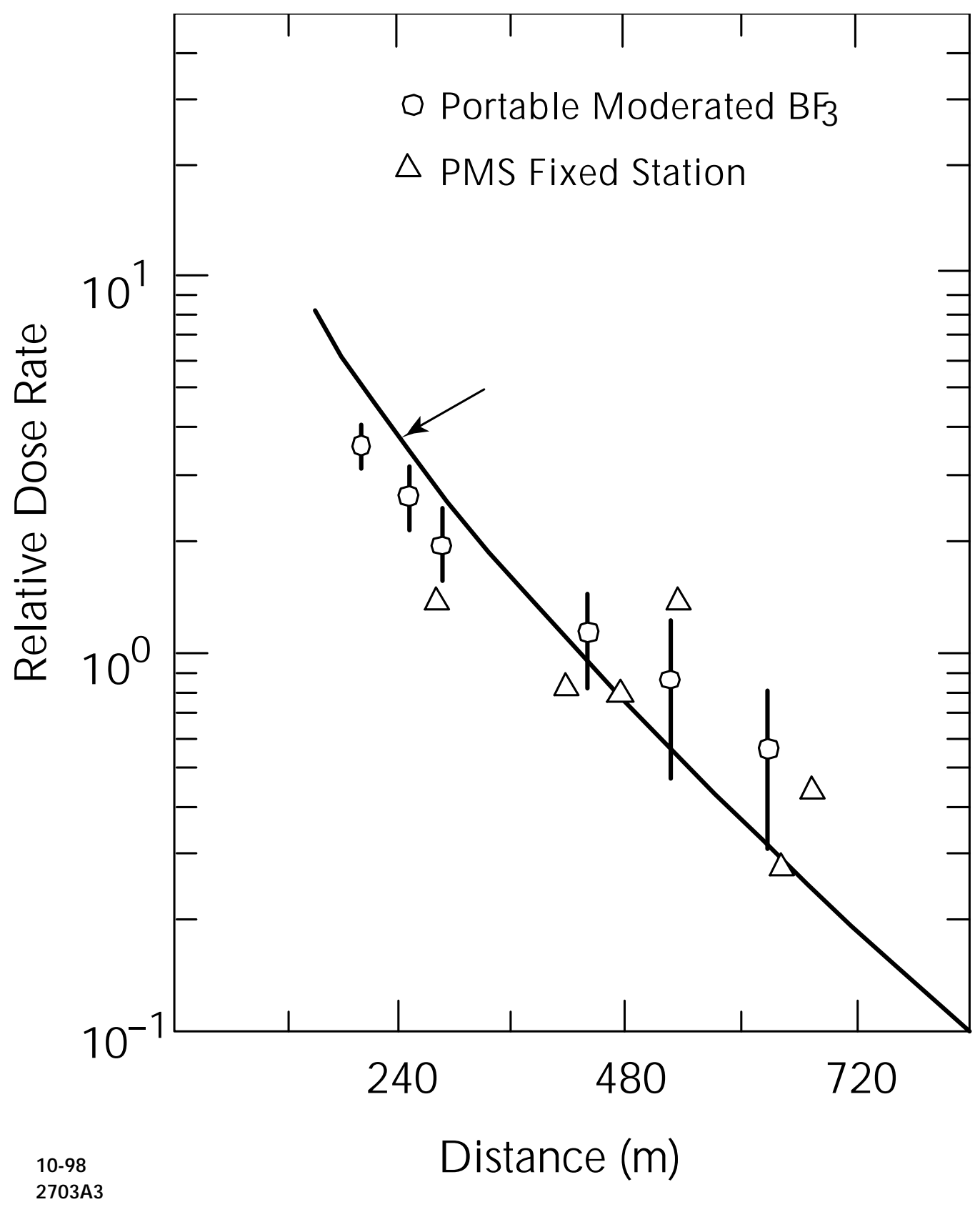

Figure A-1 Neutron Measurements Made Along a Line Between End Station A and the Site Boundary.

Note: The relative dose rate is normalized with respect to beam power. 


\section{NESHAPs Report \\ 0 riginal report published separately. Table and section formats reflect those of the original.}

\section{Facility Information}

Stanford Linear Accelerator Center (SLAC) was in full compliance in calendar year 1999 (CY99) with the requirements set forth in 40 CFR Part 61 Subpart $H$.

\subsection{Site Description}

SLAC is a national facility operated by Stanford University under contract with the U.S. Department of Energy (DOE). It is located on the San Francisco peninsula, about halfway between San Francisco and San Jose, California. The site area is a belt of low, rolling foothills, lying between the alluvial plain bordering the San Francisco Bay on the east and the Santa Cruz Mountains on the west.

The whole accelerator site varies in elevation from 53 to 114 meters (175 to 375 feet) above sea level, whereas the alluvial plain to the east around the Bay lies less than 46 meters (150 feet) above sea level. The mountains to the west rise abruptly to 610 meters (2,000 feet). The SLAC site occupies 170 hectares (420 acres) of land. The site is located in an unincorporated portion of San Mateo County. It is bordered on the north by Sand Hill Road and on the south by San Francisquito Creek.

The SLAC staff is roughly 1,400 employees, temporary staff, and visiting scientists. The climate in the SLAC area is Mediterranean. Winters are cool, with intermittent rains, and summers are mostly warm and dry.

The populated area around SLAC is a mix of office, school, university, condominiums, apartments, single family housing, and pasture. SLAC is mainly surrounded by 5 communities: Atherton town, West Menlo Park, Woodside town, Portola Valley town, and Stanford. Population distribution and housing data from the 1990 census for these five communities are shown in Table 1 below:

\section{Table 1: Demographic Data}

\begin{tabular}{|l|c|c|c|c|}
\hline G eographic Area & $\begin{array}{c}\text { Population } \\
\text { [persons] }\end{array}$ & $\begin{array}{c}\text { Pop. D ensity } \\
\text { [persons/sq. mile] }\end{array}$ & $\begin{array}{c}\text { Housing } \\
\text { [units] }\end{array}$ & $\begin{array}{c}\text { Land Area } \\
\text { [sq. mile] }\end{array}$ \\
\hline Atherton town & 7,163 & $1,463.32$ & 2,518 & 4.895 \\
\hline West Menlo Park & 3,959 & $7,086.19$ & 1,701 & 0.559 \\
\hline Portola Valley town & 4,194 & 458.02 & 1,675 & 9.157 \\
\hline Woodside town & 5,035 & 428.88 & 1,892 & 11.740 \\
\hline Stanford & 18,097 & $6,569.14$ & 4,770 & 2.755 \\
\hline Total: & 38,448 & NA & 12,556 & 29.106 \\
\hline
\end{tabular}


SLAC is a component of the U.S. high-energy physics program. The laboratory uses a 3.2 $\mathrm{km}$ ( 2 mile) long electron accelerator to produce and accelerate both electrons and positrons for basic particle physics research.

SLAC also operates the Stanford Synchrotron Radiation Laboratory (SSRL), a synchrotron research facility. This laboratory uses $3 \mathrm{GeV}$ stored electrons to generate synchrotron radiation for basic energy research.

The facilities at SLAC are used to maintain the accelerator, to design and construct new detector systems, and to support research in accelerator technology. There are a variety of facilities at SLAC that may be used at any given time. Experimental needs and schedules dictate facility use. Therefore, not every facility is significantly utilized each year. Facilities that are utilized are included in Section 1.2.

\subsection{Source Description}

Radioactive material is inevitably produced by the operation of the accelerator. During the acceleration process some electrons strike accelerator components and induce radioactivity in the material. In addition, some high-energy particles interact with air molecules producing relatively short-lived radionuclides such as $15 \mathrm{O}, 13 \mathrm{~N}, 11 \mathrm{C}$, and $41 \mathrm{Ar}$. These radioactive gases are normally produced in areas where the beam strikes beam line components (beam loss).

In a January 1998 letter to the Environmental Protection Agency (EPA), SLAC discussed three separate issues, one being what constituted an air pollution "source". The other two issues are discussed in subsequent sections. The LINear ACcelerator (linac), damping rings, positron source (PS), and the beam switchyard (BSY) can be expected to be operational on a near-constant basis. This results in potentially high accumulations of activated radionuclide gases within these specific areas. This is not true for the other facilities here, as their usage will rise and fall as experiments begin and end.

The commissioning of the Positron-Electron Project (PEP) rings, the minimal use of End Station A (ESA), and the Next Linear Collider Test Accelerator (NLCTA) at End Station B (ESB), are all examples of the changing use of these major research facilities. New experiments are continually being developed at SLAC to test newer theory. The letter to EPA stressed that SLAC has only the potential to emit radionuclides from areas of high-energy beam-loss, and that other possible sources simply did not have the potential to cause impact to the public.

There were nine potential beam loss areas identified at SLAC for CY99 where the saturation air radioactivity was produced. The SLC Beam Dumps were inactive during CY99. SLAC's nine current research facilities are as follows:

- Accelerator Housing (LINAC).

- Positron Source.

- Beam Switchyard (BSY).

- SLC Damping Rings.

- Stanford Synchrotron Radiation Laboratory (SSRL) Booster Injector.

- Final Focus Test Beam (FFTB).

- Next Linear Collider Test Accelerator (NLCTA).

- Asymmetric B-Factory (PEP-II).

- End Station A (ESA). 
The saturation radioactivity is defined to be the equilibrium air radioactivity level inside these areas when the accelerator is running. Calculations of saturation activity in each of these nine beam loss areas are conservatively based on the specific beam power loss and the area geometry (that is, air path length, air volume, and other factors).

Potential release points from these areas are either from the access openings (that is, entrance doors, access ways) or from the forced air ventilation ducts. All the access openings are closed and administratively secured during beam operation; therefore, potential releases occur only after turning off the beam. Ventilation is not used during beam operations.

SLAC operational practices use the As Low As Reasonably Achievable (ALARA) concept to minimize exposures of personnel to radiological hazards. ALARA takes precedence over research concerns at SLAC. With respect to release of activated gases due to beam loss, the gases are so short lived (a half-life of only 2 minutes for the main O-15 constituent), that simply allowing an hour to pass before unsealing an area diminishes exposures dramatically.

With ALARA as standard policy at SLAC, it is common for a sealed area to remain closed (i.e., no breach by venting or entry) until an appropriate cool-down period passes. The cool-down period allows for decay of expected activated gases and results in the ability to work without other hazards present. Electrical transients and high thermal regimes (much of the equipment runs at temperatures over 100 degrees F) pose far greater immediate risks to SLAC personnel than do radionuclides.

For SLAC's seven sealed experimental facilities, cool-down periods run from 30 to 60 minutes after the beam is shut off (refer to Tables 2 through 10). The other two facilities, PEP-II and ESA, have continuous diffusion to the atmosphere via Beam Dump East (BDE) and Interaction Region 10 (IR 10), respectively. In CY99, NLCTA was operated at low power allowing a 30-minute decay time to adequately reduce the gases produced there.

Conversely, the Positron Vault (PV) has very high energy beam losses due to interception of the linac's electron beam to produce positrons. Most of SLAC's experiments have beamloss energies between that of NLCTA and the PV, resulting in the ALARA practice of a 60minute cool-down period before venting (or entry).

It should be noted here that in some cases, if not most, the estimated diffusion to the atmosphere of activated gases is a gross over-statement of what can reasonably be expected to have been released. Even with these conservative calculations, SLAC emissions are still below EPA's accepted limits.

The calculated source terms in each area include the assumptions that the total value of air in the area is at saturation levels, and is instantaneously released whenever that area was shut down for repair or maintenance. These calculated source terms are presented in Tables 2 through 11. In addition, the "number of releases/year" was conservatively estimated for many systems.

The decay time for the produced radioactive gases prior to release varied for the different beam loss areas. Detailed descriptions of the beam loss areas and their associated radionuclide concentrations are discussed in Section 1.2.1. 


\subsubsection{Accelerator Housing}

The accelerator, or LINear ACcelerator (LINAC), is enclosed in a $3.2 \mathrm{~km}$ (2-mile) long housing. The housing is located 7.6 meters ( 25 feet) below ground. Access to the housing is through $76.2-\mathrm{cm}$ (30-inch) diameter shafts every 100.5 meters (330 feet). These shafts (release points) are also used as intake and exhaust shafts for the accelerator housing. Before machine operation, the housing is searched and locked. There is a solid cover across each access way shaft, which is interlocked with the accelerator. The cover must be in place for machine operation; consequently, the housing is not vented when the accelerator is in operation. There are no releases from these points when the machine is on. After the machine is turned off, that is, no beams are being produced, the housing can be vented.

The radioactive gas concentration is very low in the accelerator housing because there is very little beam loss, as evidenced by the level of activation in the accelerator structure. It is conservatively assumed that the saturation activities in this area are similar to those in one of the SLC Beam Dump areas.

Table 2: Accelerator Housing Activity

\begin{tabular}{|c|c|c|c|c|c|}
\hline Radionuclide & $\begin{array}{c}\text { Saturation } \\
\text { Activity (Ci) }\end{array}$ & $\begin{array}{c}\text { Estimated } \\
\text { Number of } \\
\text { Releases }\end{array}$ & $\begin{array}{c}\text { Typical Decay } \\
\text { Time (min) }\end{array}$ & $\begin{array}{c}\text { Activity } \\
\text { Released (Ci/y) }\end{array}$ & $\begin{array}{l}\text { Percent of } \\
\text { Contribution }\end{array}$ \\
\hline O-15 & $1.0 \mathrm{E}-01$ & 3 & 60 & $3.82-10$ & $0.00 \%$ \\
\hline N-13 & $2.0 \mathrm{E}-02$ & 3 & 60 & $9.23 \mathrm{E}-04$ & $5.91 \%$ \\
\hline C-11 & $3.0 \mathrm{E}-02$ & 3 & 60 & $1.16 \mathrm{E}-02$ & $74.35 \%$ \\
\hline Ar-41 & $1.5 \mathrm{E}-03$ & 3 & 60 & $3.08 \mathrm{E}-03$ & $19.74 \%$ \\
\hline Total: & $1.5 \mathrm{E}-01$ & & & $1.56 \mathrm{E}-02$ & $100.00 \%$ \\
\hline \multicolumn{7}{|c|}{ *1 Ci=3.7 x 1010 Bq } \\
\hline
\end{tabular}

After the electron beam leaves the accelerator, it is guided to an area where it may interact with a stationary target or be directed to collide with a beam of positrons. The distance from this facility to the nearest receptor (receptor defined as a member of the general public) is about 305 meters (1,000 feet). 


\subsubsection{Positron Vault}

The positron vault is located in an area separated from the accelerator housing by a thick concrete shield. The beam is deflected out of the accelerator into the positron target. The electron beam produces electron/positron pairs in the target. The positrons are separated and transported back to the beginning of the accelerator. The air activation associated with the operation of the positron target has been evaluated with respect to the saturation activities. The saturation activities of potential radioactive gases in this area are listed in Table 3.

Table 3: Positron Vault Activity

\begin{tabular}{|c|c|c|c|c|c|}
\hline Isotope & $\begin{array}{c}\text { Saturation } \\
\text { Activity (Ci) }\end{array}$ & $\begin{array}{c}\text { Estimated } \\
\text { N umber of } \\
\text { Releases }\end{array}$ & $\begin{array}{c}\text { Typical Decay } \\
\text { Time (min) }\end{array}$ & $\begin{array}{c}\text { Activity } \\
\text { Released (Ci/y) }\end{array}$ & $\begin{array}{c}\text { Percent of } \\
\text { Contribution }\end{array}$ \\
\hline O-15 & $1.4 \mathrm{E}+00$ & 9 & 60 & $1.60 \mathrm{E}-09$ & $0.00 \%$ \\
\hline N-13 & $3.0 \mathrm{E}-01$ & 9 & 60 & $4.15 \mathrm{E}-03$ & $8.10 \%$ \\
\hline $\mathrm{C}-11$ & $3.0 \mathrm{E}-01$ & 9 & 60 & $3.48 \mathrm{E}-02$ & $67.88 \%$ \\
\hline Ar-41 & $2.0 \mathrm{E}-02$ & 9 & 60 & $1.23 \mathrm{E}-02$ & $24.03 \%$ \\
\hline Total: & $2.0 \mathrm{E}+00$ & & & $5.13 \mathrm{E}-01$ & $100.00 \%$ \\
\hline
\end{tabular}

The positron source has a separate exhaust fan (release point). The positron source is not vented during machine operation. The distance to the nearest receptor is about 640 meters $(2,100$ feet).

\subsubsection{Beam Switchyard}

There are four vents (release points) at BSY. The vents at BSY and Beam Dump East (BDE) have covers. The covers are closed during beam operation. Use of the saturation activity produced in the accelerator housing, as the release from these four vents will give a conservative estimate of the effective dose equivalent. The distance from this facility to the nearest receptor is about 457 meters (1,500 feet).

\section{Table 4: Beam Switchyard Activity}

\begin{tabular}{|c|c|c|c|c|c|}
\hline Isotope & $\begin{array}{l}\text { Saturation } \\
\text { Activity (Ci) }\end{array}$ & $\begin{array}{l}\text { Estimated } \\
\text { N umber of } \\
\text { Releases }\end{array}$ & $\begin{array}{l}\text { Typical Decay } \\
\text { Time (min) }\end{array}$ & $\begin{array}{l}\text { Activity } \\
\text { Released (Ci/ } \\
\text { Y)* }\end{array}$ & $\begin{array}{l}\text { Percent of } \\
\text { Contribution }\end{array}$ \\
\hline O-15 & $1.0 \mathrm{E}-01$ & $0^{* *}$ & 60 & 0 & 0 \\
\hline $\mathrm{N}-13$ & 2.0E-02 & $0^{* *}$ & 60 & 0 & 0 \\
\hline C-11 & $3.0 \mathrm{E}-02$ & $0^{* *}$ & 60 & 0 & 0 \\
\hline Ar-41 & $1.5 \mathrm{E}-03$ & $0^{* *}$ & 60 & 0 & 0 \\
\hline Total: & $1.5 \mathrm{E}-01$ & & & 0 & 0 \\
\hline
\end{tabular}




\subsubsection{Damping Rings}

There are two damping rings associated with the SLC. The rings are located on the north and south sides of the accelerator at the end of Sector 1 . The distance from these two rings to the nearest receptor is about 274 meters (900 feet). Each ring has a forced air ventilation system (release point). No ventilation is carried out during beam operation. The saturation activity produced in each ring has been calculated. The radionuclides produced and the saturation activities are listed in Table 5.

Table 5: Damping Rings Activity

\begin{tabular}{|c|c|c|c|c|c|}
\hline Isotope & $\begin{array}{c}\text { Saturation } \\
\text { Activity (Ci) }\end{array}$ & $\begin{array}{c}\text { Estimated } \\
\text { N umber of } \\
\text { Releases }\end{array}$ & $\begin{array}{c}\text { Typical Decay } \\
\text { Time (min) }\end{array}$ & $\begin{array}{c}\text { Activity Released } \\
\text { (Ci/y) }\end{array}$ & $\begin{array}{c}\text { Percent of } \\
\text { Contribution }\end{array}$ \\
\hline O-15 & $1.8 \mathrm{E}-02$ & 7 & 60 & $1.60 \mathrm{E}-10$ & $0.00 \%$ \\
\hline N-13 & $3.2 \mathrm{E}-03$ & 7 & 60 & $3.45 \mathrm{E}-04$ & $17.84 \%$ \\
\hline C-11 & $6.0 \mathrm{E}-04$ & 7 & 60 & $5.42 \mathrm{E}-04$ & $28.05 \%$ \\
\hline Ar-41 & $2.2 \mathrm{E}-04$ & 7 & 60 & $1.04 \mathrm{E}-03$ & $54.11 \%$ \\
\hline Total: & $2.2 \mathrm{E}-02$ & & & $1.93 \mathrm{E}-03$ & $100.00 \%$ \\
\hline
\end{tabular}

$* 1 \mathrm{Ci}=3.7 \times 1010 \mathrm{~Bq}$

\subsubsection{SSRL Booster Injector}

SSRL has a $3 \mathrm{GeV}$ booster ring and linac (injector) that produce very low concentrations of radioactive gases. The Stanford Positron Electron Asymmetric Ring (SPEAR) ring of SSRL produces negligible radioactive gases because there is little to no beam loss; therefore, the SPEAR ring is not considered to be a source. The radionuclides and their saturation activities are listed in Table 6.

\section{Table 6: SSRL Booster/Injector Activity}

\begin{tabular}{|c|c|c|c|c|c|}
\hline Isotope & $\begin{array}{c}\text { Saturation } \\
\text { Activity (Ci) }\end{array}$ & $\begin{array}{c}\text { Estimated } \\
\text { Number of } \\
\text { Releases }\end{array}$ & $\begin{array}{c}\text { Typical Decay } \\
\text { Time (min) }\end{array}$ & $\begin{array}{c}\text { Activity Released } \\
\text { (Ci/y) }\end{array}$ & $\begin{array}{c}\text { Percent of } \\
\text { Contribution }\end{array}$ \\
\hline O-15 & $3.7 \mathrm{E}-04$ & 12 & 60 & $5.65 \mathrm{E}-12$ & $0.00 \%$ \\
\hline $\mathrm{N}-13$ & $7.0 \mathrm{E}-04$ & 12 & 60 & $1.29 \mathrm{E}-04$ & $37.18 \%$ \\
\hline $\mathrm{C}-11$ & $8.0 \mathrm{E}-05$ & 12 & 60 & $1.24 \mathrm{E}-04$ & $35.63 \%$ \\
\hline Ar-41 & $1.2 \mathrm{E}-05$ & 12 & 60 & $9.45 \mathrm{E}-05$ & $27.19 \%$ \\
\hline Total: & $1.2 \mathrm{E}-03$ & & & $3.47 \mathrm{E}-04$ & $100.00 \%$ \\
\hline
\end{tabular}

The booster ring does not have forced air ventilation; thus the entrance door is the only potential release point. The distance from this facility to the nearest receptor is about 427 meters (1,400 feet). 


\subsubsection{Final Focus Test Beam}

The FFTB is an extension of the old C-line from the BSY and extends out into the research yard. This facility tests technology that is used to reduce electron beam pulse sizes and increase collision probabilities for the next generation linear accelerators. The radionuclides produced and their saturation activities are listed in Table 7.

\section{Table 7: Final Focus Test Beam Activity}

\begin{tabular}{|c|c|c|c|c|c|}
\hline Isotope & $\begin{array}{c}\text { Saturation } \\
\text { Activity (Ci) }\end{array}$ & $\begin{array}{c}\text { Estimated } \\
\text { Number of } \\
\text { Releases }\end{array}$ & $\begin{array}{c}\text { Typical Decay } \\
\text { Time (min) }\end{array}$ & $\begin{array}{c}\text { Activity Released } \\
\text { (Ci/y) }\end{array}$ & $\begin{array}{c}\text { Percent of } \\
\text { Contribution }\end{array}$ \\
\hline O-15 & $1.7 \mathrm{E}-04$ & 7 & 60 & $1.51 \mathrm{E}-12$ & $0.00 \%$ \\
\hline N-13 & $3.1 \mathrm{E}-04$ & 7 & 60 & $3.34 \mathrm{E}-05$ & $46.80 \%$ \\
\hline C-11 & $3.3 \mathrm{E}-05$ & 7 & 60 & $2.98 \mathrm{E}-05$ & $41.77 \%$ \\
\hline Ar-41 & $1.7 \mathrm{E}-06$ & 7 & 60 & $8.15 \mathrm{E}-06$ & $11.43 \%$ \\
\hline Total: & $5.1 \mathrm{E}-04$ & & & $7.13 \mathrm{E}-05$ & $100.00 \%$ \\
\hline
\end{tabular}

The FFTB does not have forced air ventilation; thus the entrance door is the only potential release point. The distance from this facility to the nearest receptor is about 487 meters $(1,550$ feet).

\subsubsection{End Station A}

The End Station A (ESA) facility is used for fixed target experiments utilizing up to $50 \mathrm{GeV}$ electrons from the A-line of the BSY. The majority of the beam loss occurs at BDE, which is a 400-gallon water dump at the end of the line from ESA. The radionuclides produced and the saturation activities are listed in Table 8 . The saturation activities are recalculated for CY99 based on a new assumption for beam loss at BDE.

Table 8: End Station A Activity

\begin{tabular}{|c|c|c|c|c|c|}
\hline Isotope & $\begin{array}{c}\text { Saturation } \\
\text { Activity (Ci) }\end{array}$ & $\begin{array}{c}\text { Estimated } \\
\text { Number of } \\
\text { Releases }\end{array}$ & $\begin{array}{c}\text { Typical Decay } \\
\text { Time (min) }\end{array}$ & $\begin{array}{c}\text { Activity Released } \\
\text { (Ci/y) }\end{array}$ & $\begin{array}{c}\text { Percent of } \\
\text { Contribution }\end{array}$ \\
\hline O-15 & $4.9 \mathrm{E}-03$ & 13 & 0 & $6.41 \mathrm{E}-02$ & $31.5 \%$ \\
\hline N-13 & $9.2 \mathrm{E}-03$ & 13 & 0 & $1.20 \mathrm{E}-01$ & $58.85 \%$ \\
\hline C-11 & $9.9 \mathrm{E}-04$ & 13 & 0 & $1.28 \mathrm{E}-02$ & $6.3 \%$ \\
\hline Ar-41 & $5.2 \mathrm{E}-04$ & 13 & 0 & $6.80 \mathrm{E}-03$ & $3.343 \%$ \\
\hline Total: & $1.6 \mathrm{E}-02$ & & & $2.03 \mathrm{E}-01$ & $100.00 \%$ \\
\hline
\end{tabular}

The ESA beam loss area is located at BDE. The distance from this facility to the nearest receptor is about 457 meters (1,500 feet). BDE does not have forced air ventilation; thus the entrance door to $\mathrm{BDE}$ is the only potential release point. This entrance door is a gate and does not constitute an area isolated from the environs. Continuous air diffusion to the environs is assumed at a rate of one tunnel volume per week. For this reason, the typical decay time of 0 minutes is used. 


\subsubsection{NLCTA}

The Next Linear Collider Test Accelerator (NLCTA) facility is designed to test certain key operating principles of a large scale accelerator, the Next Linear Collider (NLC). The NLCTA is a 42 meter beamline housed in End Station B (ESB) and powered by three $50 \mathrm{MW}$ klystrons. The radionuclides produced and their saturation activities are listed in Table 9.

Table 9: NLCTA Activity

\begin{tabular}{|c|c|c|c|c|c|}
\hline Isotope & $\begin{array}{c}\text { Saturation } \\
\text { Activity (Ci) }\end{array}$ & $\begin{array}{c}\text { Estimated } \\
\text { Number of } \\
\text { Releases }\end{array}$ & $\begin{array}{c}\text { Typical D ecay } \\
\text { Time (min) }\end{array}$ & $\begin{array}{c}\text { Activity Released } \\
\text { (Ci/y) }\end{array}$ & $\begin{array}{c}\text { Percent of } \\
\text { Contribution }\end{array}$ \\
\hline O-15 & $2.5 \mathrm{E}-04$ & 9 & 30 & $7.93 \mathrm{E}-08$ & $34.45 \%$ \\
\hline N-13 & $3.8 \mathrm{E}-04$ & 9 & 30 & $1.22 \mathrm{E}-07$ & $53.00 \%$ \\
\hline C-11 & $1.9 \mathrm{E}-05$ & 9 & 30 & $6.10 \mathrm{E}-09$ & $2.65 \%$ \\
\hline Ar-41 & $7.1 \mathrm{E}-05$ & 9 & 30 & $2.28 \mathrm{E}-08$ & $9.90 \%$ \\
\hline Total: & $7.2 \mathrm{E}-04$ & & & $2.30 \mathrm{E}-07$ & $100.00 \%$ \\
\hline
\end{tabular}

The NLCTA beam loss area is located at ESB. The distance from this facility to the nearest receptor is about 580 meters (1,900 feet) to the north. The NLCTA does not have forced ventilators; thus the entrance door is the only potential release point.

\subsubsection{PEP-II}

The PEP-II Asymmetric B-Factory (PEP-II) facility consists of two independent storage rings, which store $9 \mathrm{GeV}$ electrons and $3.1 \mathrm{GeV}$ positrons, respectively. This facility is designed to collide electrons and positrons with different energies; thus studying the physics behind $\mathrm{CP}$ violations. The radionuclides produced and the saturation activities are listed in Table 10. The saturation activities and activity released have increased due to higher power levels and facility usage.

Table 10: PEP-II Activity

\begin{tabular}{|c|c|c|c|c|c|}
\hline Isotope & $\begin{array}{c}\text { Saturation } \\
\text { Activity (Ci) }\end{array}$ & $\begin{array}{c}\text { Estimated } \\
\text { Number of } \\
\text { Releases }\end{array}$ & $\begin{array}{c}\text { Typical Decay } \\
\text { Time (min) }\end{array}$ & $\begin{array}{c}\text { Activity Released } \\
\text { (Ci/y) }\end{array}$ & $\begin{array}{c}\text { Percent of } \\
\text { Contribution }\end{array}$ \\
\hline O-15 & $2.46 \mathrm{E}-03$ & 3020 & 0 & $7.43 \mathrm{E}+00$ & $28.08 \%$ \\
\hline N-13 & $4.60 \mathrm{E}-03$ & 3020 & 0 & $1.39 \mathrm{E}+01$ & $52.5 \%$ \\
\hline C-11 & $4.92 \mathrm{E}-04$ & 3020 & 0 & $1.49 \mathrm{E}+00$ & $5.62 \%$ \\
\hline Ar-41 & $1.21 \mathrm{E}-03$ & 3020 & 0 & $3.65 \mathrm{E}+00$ & $13.81 \%$ \\
\hline Total: & $8.8 \mathrm{E}-03$ & & & $2.65 \mathrm{E}+01$ & $100.00 \%$ \\
\hline
\end{tabular}

The PEP-II beam loss areas are located at IR- 8 and IR-10. A conservative assumption is made that all activated air for the PEP-II facility will be released from the IR-10 facility, which is located closer to the site boundary. The closest member of the general public is located NNE or IR 10 at 427 meters (1,400 feet). The IR-8 facility does not constitute an area isolated from the environs.

Continuous air diffusion to the environs is assumed at a rate of one facility volume every 2 hours. For this reason, the typical decay time of 0 minutes is used. The radionuclide activities used for assessing compliance are listed in Table 12. These activities were calculated using internal reports and memorandum to file. 
Table 11: Summary Activity by Location for CY99

\begin{tabular}{|c|c|c|c|c|c|c|c|c|c|c|c|}
\hline Isotope & $\begin{array}{c}\text { Accelerator } \\
\text { Housing } \\
{\left[\mathrm{CC}^{\mathrm{a}}\right]}\end{array}$ & $\begin{array}{c}\text { Positron } \\
\text { Source } \\
\text { [Ci*] }\end{array}$ & $\begin{array}{c}\text { Beam } \\
\text { Switchyard } \\
{\left[\mathrm{Ci}^{\mathbf{1}}\right]}\end{array}$ & $\begin{array}{c}\text { SLC Damping } \\
\text { Rings }\left[\mathrm{Ci}^{1}\right]\end{array}$ & $\begin{array}{l}\text { SSRL Booster/ } \\
\text { Injector }\left[\mathrm{Ci}^{1}\right]\end{array}$ & FFIB $\left[\mathrm{Ci}^{\mathbf{1}}\right]$ & $\begin{array}{l}\text { ESA } \\
{\left[\mathrm{Ci}^{\mathbf{1}}\right]}\end{array}$ & $\begin{array}{c}\text { NLCTA } \\
{\left[\mathrm{Ci}^{\mathbf{1}}\right]}\end{array}$ & $\begin{array}{c}\text { PEP-II } \\
{\left[\mathrm{Ci}^{\mathbf{1}}\right]}\end{array}$ & $\begin{array}{c}\text { All Site } \\
\text { Total }\left(\mathbf{C i}^{1}\right)\end{array}$ & $\begin{array}{l}\text { Percent of } \\
\text { Contribution }\end{array}$ \\
\hline O-15 & $3.8 \mathrm{E}-10$ & $1.6 \mathrm{E}-08$ & $0.0 \mathrm{E}-00$ & $1.6 \mathrm{E}-10$ & $5.6 \mathrm{E}-12$ & $1.5 \mathrm{E}-12$ & 6.4E-02 & $7.9 \mathrm{E}-08$ & $7.4 \mathrm{E}+00$ & $7.5 \mathrm{E}+00$ & $27.55 \%$ \\
\hline $\mathrm{N}-13$ & $9.2 \mathrm{E}-04$ & $4.2 \mathrm{E}-02$ & $0.0 \mathrm{E}-00$ & $3.4 \mathrm{E}-04$ & $1.3 \mathrm{E}-04$ & 3.3E-05 & $1.2 \mathrm{E}-01$ & $1.2 \mathrm{E}-07$ & $1.4 \mathrm{E}+01$ & $1.4 \mathrm{E}+01$ & $51.68 \%$ \\
\hline C-11 & $1.2 \mathrm{E}-02$ & $3.5 \mathrm{E}-01$ & $0.0 \mathrm{E}-00$ & 5.4E-04 & $1.2 \mathrm{E}-04$ & $3.0 \mathrm{E}-05$ & $1.3 \mathrm{E}-02$ & $6.1 \mathrm{E}-09$ & $1.5 \mathrm{E}+00$ & $1.9 \mathrm{E}+00$ & $6.84 \%$ \\
\hline Ar-41 & $3.1 \mathrm{E}-03$ & $1.2 \mathrm{E}-01$ & $0.0 \mathrm{E}-00$ & $1.0 \mathrm{E}-03$ & $9.4 \mathrm{E}-05$ & $8.1 \mathrm{E}-06$ & $6.8 \mathrm{E}-03$ & $2.3 \mathrm{E}-08$ & $3.7 \mathrm{E}+00$ & $3.8 \mathrm{E}+00$ & $13.93 \%$ \\
\hline Total: & $1.6 \mathrm{E}-02$ & 5.1E-01 & $0.0 \mathrm{E}-00$ & $1.9 \mathrm{E}-03$ & 3.5E-04 & 7.1E-05 & 2.0E-01 & 2.3E-07 & $2.6 \mathrm{E}+01$ & 2.7E+01 & \\
\hline \begin{tabular}{|c|} 
Percent of \\
Contribution \\
\end{tabular} & $0.04 \%$ & $1.26 \%$ & $0.00 \%$ & $0.00 \%$ & $0.00 \%$ & $0.00 \%$ & $0.75 \%$ & $0.00 \%$ & $97.30 \%$ & & $100.00 \%$ \\
\hline
\end{tabular}

a $1 \mathrm{Ci}=3.7 \times 1010 \mathrm{~Bq}$ 


\section{Air Emissions Data}

\begin{tabular}{|c|c|c|c|}
\hline Nearest Point Source & Type Control $^{\text {a }}$ & Efficiency $^{3}$ & Distance to Receptor \\
\hline Positron Source & Not vented during beam operation & $100 \%$ & $640 \mathrm{~m} \quad$ (NNE) \\
\hline Damping Ring & Not vented during beam operation & $100 \%$ & $274 \mathrm{~m} \quad(\mathrm{WNW})$ \\
\hline Accelerator Housing & Not vented during beam operation & $100 \%$ & $305 \mathrm{~m}$ \\
\hline Beam Switchyard & Not vented during beam operation & $100 \%$ & $457 \mathrm{~m}(\mathrm{NNW})$ \\
\hline SSRL Booster/Injector & Not vented during beam operation & $100 \%$ & $427 \mathrm{~m}$ \\
\hline FFTB & Not vented during beam operation & $100 \%$ & $487 \mathrm{~m}$ \\
\hline End Station A & $\begin{array}{l}\text { Not vented during beam operation; how- } \\
\text { ever since this is not a closed facility, emis- } \\
\text { sion occurs by diffusion. }\end{array}$ & $100 \%$ & $457 \mathrm{~m}$ \\
\hline NLCTA & Not vented during beam operation. & $100 \%$ & $580 \mathrm{~m}$ \\
\hline PEP-II & $\begin{array}{l}\text { Not vented during beam operation; how- } \\
\text { ever since this is not a closed facility, emis- } \\
\text { sion occurs by diffusion. }\end{array}$ & $100 \%$ & $(\mathrm{NNE})$ \\
\hline
\end{tabular}

a There are no controls during venting, so efficiency is not applicable.

\begin{tabular}{|c|c|}
\hline Non-Point Source & Annual Quantity (Ci) \\
\hline None Identified & 0.0 \\
\hline
\end{tabular}

Table 12: Total Radioactive Gases Potentially Released in CY99 (Decay/Venting Delay Corrected)

\begin{tabular}{|c|c|c|}
\hline Isotope & All Site Total $\left(\mathbf{C i}^{\mathbf{a}}\right)$ & Percent of Contribution \\
\hline $\mathrm{O}-15$ & $7.5 \mathrm{E}+00$ & $27.55 \%$ \\
\hline $\mathrm{N}-13$ & $1.4 \mathrm{E}+01$ & $51.68 \%$ \\
\hline $\mathrm{C}-11$ & $1.9 \mathrm{E}+00$ & $6.84 \%$ \\
\hline Ar-41 & $3.8 \mathrm{E}+00$ & $13.93 \%$ \\
\hline Total $(\mathrm{Ci}):$ & $2.7 \mathrm{E}+01$ & $100.00 \%$ \\
a $1 \mathrm{Ci}=3.7 \times 1010 \mathrm{~Bq}$ &
\end{tabular}




\section{Dose Assessments}

\subsection{Description of the Dose Model}

The EPA atmospheric dispersion/radiation dose calculation computer code, CAP88-PC Version 1.0, was used to calculate the average radiation dose to individuals at specified distances and directions from the facility and to individuals within each population segment around the facility. Collective population dose is calculated as the average radiation dose to an individual in a specified area, multiplied by the number of individuals in that area.

The CY99 radioactivity air emissions were conservatively derived and are shown in Table 11 in Section 2. The "number of releases/year" was estimated for each release point. This parameter was purely based on the number of times that the machine was shut down for repair or maintenance in CY99, and was independent of whether or not venting was carried out. The typical period of time after the accelerator was shut down till the opening of the housing for entries in CY99 was about one hour for each of the beam loss areas. These beam loss areaspecific decay times were used to calculate the remaining inventory of radioactive gases prior to release.

As noted in the previous discussion in sections 1.2.7 and 1.2.9, potential releases from ESA and PEP-II are atypical of SLAC release points. Through BDE, ESA is not isolated from the environs and has been calculated to diffuse through the BDE entrance door at the rate of one tunnel volume per week. Similarly PEP-II operations at IR 8 and IR 10 allow diffusion to the atmosphere, as each of these areas is unisolated from the environs. It is assumed that all diffusion takes place from IR 10, which is more proximal to the general public; and at a rate of one facility volume every two hours.

Each release point was conservatively modeled as a single point source with a stack height of 0.0 meter and a diameter of 0.0 meter. The distances in meters (feet) from each single release point to the respective nearest receptors were specifically noted. The dose assessment model consisted of two parts:

1 Individual source term releases, which took into account the closest receptor and contributions from all other sources to that receptor in order to find the appropriate or "real" Maximally Exposed Individual (MEI).

2 A collective source term release, which was used to determine a collective Effective Dose Equivalent (EDE) to the surrounding population, out to $80 \mathrm{~km}$.

Part 1 of the assessment model included determining where the closest and highest exposed individual resides for each source term and adding the dose contributions from all the other source terms to that individual. This calculation was carried out for each of the ten source terms separately since a point source model of release from the collective sources at SLAC was inappropriate for the nearest receptors. The MEI from each source term (with the appropriate contributions from the other source terms) was compared and the highest of these was considered the MEI for SLAC.

Determination of the MEI resulted in locating that individual near Sand Hill Road on the North/Northeast side of the SLAC facility. Details of this evaluation can be found in Table 13. 
Part 2 of the assessment model utilized the radial population grid (shown in Table 14) to calculate the collective dose in person-rem to the surrounding population out to $80 \mathrm{~km}$. In this case, the source term was modeled as the ten sources taken as a point source to the population. The point source model was appropriate for the collective EDE calculations at distances out to $80 \mathrm{~km}$.

An estimate of the population residing within $80 \mathrm{~km}$ of SLAC was made using 1990 census data. An area defined by a circle of $80 \mathrm{~km}$ radius around the center of SLAC (Sector 30) was further divided into 16 equal sectors, with segments formed by the intersection of the sectors and a total of 13 radial distances of $0.1,0.3,0.5,1.0,2.0,4.0,6.0,8.0,10.0,30.0,40.0,60.0$, and $80.0 \mathrm{~km}$. The population within each segment was derived by multiplying the segment area by the population density of the appropriate city/cities. Unpopulated areas, that is, mountains and pastures were also taken into account in this population study.

Since SLAC does not have a qualified weather station, meteorological input data for CY99 was based on the averaged data provided for San Francisco Airport (SFO) which most closely represented the local conditions at SLAC. The January 1998 EPA letter references the SFO data as the most valid and representative data set that applies to SLAC. In addition, previous parametric studies have shown that meteorological data did not significantly affect the final results and the use of SFO meteorological data in CAP88-PC yielded reasonably conservative results for both the MEI and the collective EDE. 
Table 13: Determination of Maximally Exposed Individual

\begin{tabular}{|c|c|c|c|c|c|c|}
\hline Run Name & & Source & Contributors & Location & ED E (mrem/yr) & Total (mrem/yr) \\
\hline \multirow[t]{11}{*}{ SLC99 } & \multirow[t]{11}{*}{1} & \multirow[t]{11}{*}{ SLC Beam Dumps } & & $274 m \quad N E$ & 0.00 & \\
\hline & & & SSRL & $792 m \quad$ ENE & $1.90 \mathrm{E}-07$ & \\
\hline & & & BSY & $1,097 \mathrm{~m} \quad \mathrm{NE}$ & 0.00 & \\
\hline & & & LINAC & $1,372 \mathrm{~m} \quad \mathrm{ENE}$ & $2.70 \mathrm{E}-06$ & \\
\hline & & & Positron Vault & $2,195 \mathrm{~m} \quad \mathrm{E}$ & $7.50 \mathrm{E}-05$ & \\
\hline & & & Damping Rings & $3,962 \mathrm{~m} \quad \mathrm{E}$ & $3.40 \mathrm{E}-07$ & \\
\hline & & & FFTB & $852 \mathrm{~m} \quad$ ENE & $2.70 \mathrm{E}-08$ & \\
\hline & & & ESA & 822m $\quad$ ENE & $5.000 \mathrm{E}-05$ & \\
\hline & & & NLCTA & $730 \mathrm{~m} \quad \mathrm{NE}$ & $6.30 \mathrm{E}-11$ & \\
\hline & & & PEP-II & 915m ENE & $7.040 \mathrm{E}-03$ & \\
\hline & & & & & & $7.16 \mathrm{E}-03$ \\
\hline \multirow[t]{11}{*}{ SSRL99 } & \multirow[t]{11}{*}{2} & \multirow[t]{11}{*}{ SSRL } & & $427 \mathrm{~m} \quad \mathrm{~N}$ & $1.30 \mathrm{E}-06$ & \\
\hline & & & Dumps & $731 \mathrm{~m} \quad \mathrm{NW}$ & 0.00 & \\
\hline & & & BSY & $640 \mathrm{~m} \quad \mathrm{NNE}$ & 0.00 & \\
\hline & & & LINAC & $792 \mathrm{~m} \quad \mathrm{NE}$ & $6.50 \mathrm{E}-06$ & \\
\hline & & & Positron Vault & $1,554 \mathrm{~m} \quad \mathrm{NE}$ & $5.30 \mathrm{E}-05$ & \\
\hline & & & Damping Rings & $3,353 \mathrm{~m} \quad \mathrm{ENE}$ & $1.80 \mathrm{E}-07$ & \\
\hline & & & FFTB & $487 \mathrm{~m} \mathrm{~N}$ & $1.70 \mathrm{E}-07$ & \\
\hline & & & ESA & $457 \mathrm{~m} \mathrm{~N}$ & 3.60E-04 & \\
\hline & & & NLCTA & $580 \mathrm{~m} \quad \mathrm{~N}$ & $2.50 \mathrm{E}-10$ & \\
\hline & & & PEP-II & $427 \mathrm{~m} \mathrm{~N}$ & $3.150 \mathrm{E}-02$ & \\
\hline & & & & & & 3.19E-02 \\
\hline \multirow[t]{11}{*}{ BSY99 } & \multirow[t]{11}{*}{3} & \multirow[t]{11}{*}{ BSY } & \multicolumn{2}{|r|}{$457 \mathrm{~m} \quad \mathrm{NNW}$} & 0.00 & \\
\hline & & & SSRL & $640 \mathrm{~m} \quad \mathrm{NW}$ & $2.50 \mathrm{E}-07$ & \\
\hline & & & Dumps & $1,280 \mathrm{~m} \quad$ WNW & 0.00 & \\
\hline & & & LINAC & $366 \mathrm{~m} \quad \mathrm{NNW}$ & $4.00 \mathrm{E}-05$ & \\
\hline & & & Positron Vault & $640 \mathrm{~m} \quad \mathrm{NE}$ & $3.50 \mathrm{E}-04$ & \\
\hline & & & Damping Rings & $2,743 \mathrm{~m} \quad$ ENE & $2.80 \mathrm{E}-07$ & \\
\hline & & & FFTB & $700 \mathrm{~m} \quad \mathrm{NW}$ & $3.50 \mathrm{E}-08$ & \\
\hline & & & ESA & $670 \mathrm{~m} \quad \mathrm{NW}$ & $6.70 \mathrm{E}-05$ & \\
\hline & & & NLCTA & $820 \mathrm{~m} \quad \mathrm{WNW}$ & 3.30E-11 & \\
\hline & & & PEP-II & $610 \mathrm{~m} \quad \mathrm{~W}$ & $5.78 \mathrm{E}-03$ & \\
\hline & & & & & & $6.240 \mathrm{E}-03$ \\
\hline \multirow[t]{11}{*}{ Linac99 } & \multirow[t]{11}{*}{4} & \multirow[t]{11}{*}{ Linac } & \multicolumn{2}{|r|}{$305 \mathrm{~m} \quad \mathrm{~N}$} & $1.20 \mathrm{E}-04$ & \\
\hline & & & BSY & $457 \mathrm{~m} \quad \mathrm{NW}$ & 0.00 & \\
\hline & & & SSRL & $640 \mathrm{~m} \quad \mathrm{WNW}$ & $1.50 \mathrm{E}-07$ & \\
\hline & & & Dumps & $1,280 \mathrm{~m} \quad W N W$ & 0.00 & \\
\hline & & & Positron Vault & $792 \mathrm{~m} \quad \mathrm{NE}$ & $2.20 \mathrm{E}-04$ & \\
\hline & & & Damping Rings & $2,438 \mathrm{~m} \quad$ ENE & 3.70E-07 & \\
\hline & & & FFTB & $700 \mathrm{~m} \quad \mathrm{WNW}$ & $2.20 \mathrm{E}-08$ & \\
\hline & & & ESA & $670 \mathrm{~m} \quad \mathrm{WNW}$ & $4.400 \mathrm{E}-05$ & \\
\hline & & & NLCTA & $820 \mathrm{~m} \quad \mathrm{WNW}$ & $3.30 \mathrm{E}-11$ & \\
\hline & & & PEP-II & $610 \mathrm{~m} \quad \mathrm{~W}$ & $5.78 \mathrm{E}-03$ & \\
\hline & & & & & & 6.16E-03 \\
\hline \multirow[t]{10}{*}{ PV99 } & \multirow[t]{10}{*}{5} & \multirow[t]{10}{*}{ Positron Vault } & & $640 \mathrm{~m} \quad \mathrm{NNE}$ & $3.60 \mathrm{E}-04$ & \\
\hline & & & LINAC & $731 \mathrm{~m} \quad \mathrm{NNW}$ & $9.00 \mathrm{E}-06$ & \\
\hline & & & BSY & $914 \mathrm{~m} \quad \mathrm{NW}$ & 0.00 & \\
\hline & & & SSRL & $1,097 \mathrm{~m} \quad \mathrm{NW}$ & 7.70E-08 & \\
\hline & & & Dumps & $1,676 \mathrm{~m} \quad \mathrm{NW}$ & 0.00 & \\
\hline & & & Damping Rings & $2,195 \mathrm{~m} \quad \mathrm{NE}$ & $3.40 \mathrm{E}-07$ & \\
\hline & & & FFTB & $1,157 \mathrm{~m} \quad \mathrm{NW}$ & $1.10 \mathrm{E}-08$ & \\
\hline & & & ESA & $1,127 \mathrm{~m} \quad \mathrm{NW}$ & $1.80 \mathrm{E}-05$ & \\
\hline & & & NLCTA & $820 \mathrm{~m} \quad \mathrm{WNW}$ & 3.30E-11 & \\
\hline & & & PEP-II & $610 \mathrm{~m} \quad \mathrm{~W}$ & 5.78E-03 & 6.17E-03 \\
\hline
\end{tabular}

* Location is defined as the distance and direction from the source to the closest and highest dose individual. 
Table 13 (continued) Determination of Maximally Exposed Individual

\begin{tabular}{|c|c|c|c|c|c|c|}
\hline \multirow{2}{*}{\begin{tabular}{|c|} 
Run Name \\
\end{tabular}} & \multicolumn{2}{|c|}{ Source } & Contributors & Location & \multirow{2}{*}{\begin{tabular}{|c} 
ED E (mrem/yr) \\
$2.30 \mathrm{E}-05$
\end{tabular}} & \multirow[t]{2}{*}{ Total (mrem/yr) } \\
\hline & 6 & Damping Rings & \multicolumn{2}{|r|}{$274 \mathrm{~m} \mathrm{WNW}$} & & \\
\hline & & & Positron Vault & $2,195 \mathrm{~m} \quad W$ & 1.30E-05 & \\
\hline & & & LINAC & $2,743 \mathrm{~m}$ & $2.20 \mathrm{E}-07$ & \\
\hline & & & BSY & $3,048 \mathrm{~m}$ & 0.00 & \\
\hline & & & SSRL & $3,353 \mathrm{~m}$ & 3.30E-09 & \\
\hline & & & Dumps & $3,962 \mathrm{~m}$ & 0.00 & \\
\hline & & & FFTB & $3,353 \mathrm{~m}$ & $4.60 \mathrm{E}-10$ & \\
\hline & & & ESA & $3,353 \mathrm{~m} \quad W$ & $5.90 \mathrm{E}-07$ & \\
\hline & & & NLCTA & $3,600 \mathrm{~m} \quad$ WSW & $6.80 \mathrm{E}-13$ & \\
\hline & & & PEP-II & $3,440 \mathrm{~m} \quad$ WSW & $1.20 \mathrm{E}-04$ & \\
\hline & & & & & & $1.57 \mathrm{E}-04$ \\
\hline \multirow[t]{11}{*}{ FFTB99 } & 7 & FFTB & \multicolumn{2}{|r|}{$487 \mathrm{~m} \quad \mathrm{~N}$} & 1.70E-07 & \\
\hline & & & Damping Rings & $3,353 \mathrm{~m} \quad \mathrm{ENE}$ & $1.80 \mathrm{E}-07$ & \\
\hline & & & Positron Vault & $1,554 \mathrm{~m} \quad \mathrm{NE}$ & 5.30E-05 & \\
\hline & & & LINAC & $792 \mathrm{~m} \quad \mathrm{NE}$ & $6.50 \mathrm{E}-06$ & \\
\hline & & & BSY & $640 \mathrm{~m} \quad \mathrm{NNE}$ & 0.00 & \\
\hline & & & SSRL & $427 \mathrm{~m} \quad \mathrm{~N}$ & 1.30E-06 & \\
\hline & & & Dumps & $731 \mathrm{~m} \quad \mathrm{NW}$ & 0.00 & \\
\hline & & & ESA & $457 \mathrm{~m} \quad \mathrm{~N}$ & $3.60 \mathrm{E}-04$ & \\
\hline & & & NLCTA & $580 \mathrm{~m} \quad \mathrm{~N}$ & $2.50 \mathrm{E}-10$ & \\
\hline & & & PEP-II & $427 \mathrm{~m} \quad \mathrm{~N}$ & $3.150 \mathrm{E}-02$ & \\
\hline & & & & & & 3.19E-02 \\
\hline \multirow[t]{11}{*}{ ESA99 } & \multirow[t]{11}{*}{8} & \multirow[t]{11}{*}{ ESA } & \multicolumn{2}{|r|}{$457 \mathrm{~m} \quad \mathrm{~N}$} & 3.60E-04 & \\
\hline & & & Damping Rings & $3,353 \mathrm{~m} \quad \mathrm{ENE}$ & 1.80E-07 & \\
\hline & & & Positron Vault & $1,554 \mathrm{~m} \quad \mathrm{NE}$ & $5.30 \mathrm{E}-05$ & \\
\hline & & & LINAC & $792 \mathrm{~m} \quad \mathrm{NE}$ & $6.50 \mathrm{E}-06$ & \\
\hline & & & BSY & $640 \mathrm{~m} \quad \mathrm{NNE}$ & 0.00 & \\
\hline & & & SSRL & $427 \mathrm{~m} \quad \mathrm{~N}$ & 1.30E-06 & \\
\hline & & & Dumps & $731 \mathrm{~m} \quad \mathrm{NW}$ & 0.00 & \\
\hline & & & FFTB & $487 \mathrm{~m} \quad \mathrm{~N}$ & $1.70 \mathrm{E}-07$ & \\
\hline & & & NLCTA & $580 \mathrm{~m} \quad \mathrm{~N}$ & $1.10 \mathrm{E}-10$ & \\
\hline & & & PEP-II & $427 \mathrm{~m} \quad \mathrm{NNE}$ & $3.15 \mathrm{E}-02$ & \\
\hline & & & & & & 3.19E-02 \\
\hline \multirow[t]{11}{*}{ NLCTA99 } & \multirow[t]{11}{*}{9} & \multirow[t]{11}{*}{ NLCTA } & \multicolumn{2}{|r|}{$580 \mathrm{~m} \quad \mathrm{NNW}$} & $1.30 \mathrm{E}-10$ & \\
\hline & & & Damping Rings & $3,353 \mathrm{~m} \quad$ ENE & $1.80 \mathrm{E}-07$ & \\
\hline & & & Positron Vault & $1,554 \mathrm{~m} \quad \mathrm{NE}$ & $5.30 \mathrm{E}-05$ & \\
\hline & & & LINAC & $792 \mathrm{~m} \quad \mathrm{NE}$ & $6.50 \mathrm{E}-06$ & \\
\hline & & & BSY & $640 \mathrm{~m} \quad \mathrm{NNE}$ & 0.00 & \\
\hline & & & SSRL & $427 \mathrm{~m} \quad \mathrm{~N}$ & $1.30 \mathrm{E}-06$ & \\
\hline & & & Dumps & $731 \mathrm{~m} \quad \mathrm{NW}$ & 0.00 & \\
\hline & & & ESA & $457 \mathrm{~m} \quad \mathrm{~N}$ & $3.60 \mathrm{E}-04$ & \\
\hline & & & FFTB & $487 \mathrm{~m} \quad \mathrm{~N}$ & $1.70 \mathrm{E}-07$ & \\
\hline & & & PEP-II & $427 \mathrm{~m} \quad \mathrm{NNE}$ & $3.15 \mathrm{E}-02$ & \\
\hline & & & & & & $3.19 \mathrm{E}-02$ \\
\hline PEP-II99 & 10 & PEP-II & & $427 \mathrm{~m} \quad \mathrm{NNE}$ & $3.15 \mathrm{E}-02$ & \\
\hline & & & Damping Rings & $3,353 \mathrm{~m} \quad$ ENE & $1.80 \mathrm{E}-07$ & \\
\hline & & & Positron Vault & $1,554 \mathrm{~m} \quad \mathrm{NE}$ & 5.30E-05 & \\
\hline & & & LINAC & $792 \mathrm{~m}$ & $6.50 \mathrm{E}-06$ & \\
\hline & & & BSY & $640 \mathrm{~m} \quad \mathrm{NNE}$ & 0.00 & \\
\hline & & & SSRL & $427 \mathrm{~m} \quad \mathrm{~N}$ & $1.30 \mathrm{E}-06$ & \\
\hline & & & Dumps & $731 \mathrm{~m} \quad \mathrm{NW}$ & 0.00 & \\
\hline & & & FFTB & $487 \mathrm{~m}$ & $1.70 \mathrm{E}-07$ & \\
\hline & & & ESA & $457 \mathrm{~m} \quad \mathrm{~N}$ & $3.60 \mathrm{E}-04$ & \\
\hline & & & NLCTA & $580 \mathrm{~m} \quad \mathrm{NNW}$ & $1.30 \mathrm{E}-10$ & \\
\hline & & & & & & $3.19 \mathrm{E}-02$ \\
\hline
\end{tabular}

* Location is defined as the distance and direction from the source to the closest and highest dose individual. 
Table 14: Radial Population Data for CAP88-PC

\begin{tabular}{|c|c|c|c|c|c|c|c|c|c|c|c|c|c|c|}
\hline Direction & $0.1 \mathrm{~km}$ & $0.3 \mathrm{~km}$ & $0.5 \mathrm{~km}$ & $1.0 \mathrm{~km}$ & $2.0 \mathrm{~km}$ & $4.0 \mathrm{~km}$ & $6.0 \mathrm{~km}$ & $8.0 \mathrm{~km}$ & $10.0 \mathrm{~km}$ & $30.0 \mathrm{~km}$ & $40.0 \mathrm{~km}$ & $60.0 \mathrm{~km}$ & $80.0 \mathrm{~km}$ & Total \\
\hline $\mathrm{N}$ & 0 & 0 & 125 & 403 & 1100 & 1331 & 4103 & 23994 & 18447 & 28176 & 0 & 330284 & 321492 & 729455 \\
\hline NNW & 0 & 0 & 126 & 403 & 1292 & 1696 & 4956 & 21485 & 19690 & 127166 & 96225 & 816270 & 184076 & 1273385 \\
\hline NW & 0 & 0 & 127 & 403 & 1292 & 1231 & 1803 & 2671 & 2617 & 25645 & 18835 & 0 & 0 & 54624 \\
\hline WNW & 0 & 0 & 127 & 403 & 1289 & 910 & 650 & 503 & 503 & 13312 & 3002 & 0 & 0 & 20699 \\
\hline $\mathrm{W}$ & 0 & 0 & 125 & 379 & 149 & 793 & 650 & 0 & 0 & 100 & 0 & 0 & 0 & 2196 \\
\hline WSW & 0 & 0 & 12 & 0 & 0 & 715 & 520 & 503 & 0 & 120 & 0 & 0 & 0 & 1870 \\
\hline SW & 0 & 0 & 12 & 0 & 0 & 242 & 668 & 210 & 0 & 420 & 0 & 0 & 0 & 1552 \\
\hline SSW & 0 & 0 & 12 & 0 & 0 & 417 & 690 & 0 & 420 & 0 & 0 & 0 & 0 & 1539 \\
\hline$S$ & 0 & 0 & 12 & 0 & 1195 & 1529 & 913 & 1118 & 5590 & 0 & 6725 & 37754 & 24520 & 79356 \\
\hline SSE & 0 & 0 & 12 & 0 & 1195 & 1529 & 3579 & 1878 & 3006 & 28061 & 27357 & 24520 & 58692 & 149829 \\
\hline ESE & 0 & 0 & 12 & 0 & 896 & 598 & 4855 & 17926 & 25498 & 130550 & 391124 & 234674 & 0 & 806133 \\
\hline E & 0 & 0 & 125 & 0 & 1195 & 5976 & 4855 & 22360 & 11180 & 50686 & 156449 & 0 & 0 & 252826 \\
\hline ENE & 0 & 0 & 125 & 40 & 1322 & 5976 & 5174 & 15870 & 4690 & 107196 & 69336 & 78923 & 28370 & 317022 \\
\hline $\mathrm{NE}$ & 0 & 0 & 125 & 391 & 869 & 4944 & 3773 & 8669 & 5608 & 53762 & 22300 & 23229 & 0 & 123670 \\
\hline NNE & 0 & 0 & 125 & 403 & 1416 & 2597 & 3623 & 12564 & 6607 & 0 & 170278 & 160746 & 321492 & 679851 \\
\hline TOTAL: & 0 & 0 & 1214 & 2825 & 14106 & 31679 & 42832 & 131629 & 114377 & 665574 & 1232353 & 1716571 & 964283 & 4917443 \\
\hline
\end{tabular}

-SEE ATTACHMENTS FOR OTHER INPUT PARAMETERS 


\subsection{Compliance Assessment}

During EPA's December 1997 meeting with SLAC representatives, the question of confirmatory monitoring was raised. The question was subsequently answered in detail in a January 9 letter from Roger Sit to Mr. Rosenblum. In that letter, SLAC defended the practice of demonstrating that a large degree of conservatism was used in the selection of inputs to the NESHAPs-mandated CAP88PC modeling, and the use of grab samples to confirm the conservatism of the saturation activities.

This intentional "double conservatism" in SLAC's selection of input parameters and calculations-based data, coupled with confirmatory grab samples, offers reasonable assurance that the results of our CAP88PC modeling portray an overstatement of the potential emissions from SLAC. SLAC believes that it has met the intention of the 40CFR61 $\mathrm{H}$ requirements, and has adequately addressed the request for detailed rationale requested by the regulators in this matter.

This assessment of the potential radioactivity released is based on calculations of the activity produced and other conservative assumptions as stated in Section 3.1, Description of the Dose Model. This compliance assessment used the computer code CAP88-PC Version 1.0 to calculate the dose for CY99.

Maximally Exposed Individual

Effective Dose Equivalent:

$\underline{3.19 \times 10^{-2}} \underline{\underline{\mathrm{mrem}} / \text { year }\left(3.19 \times 10^{-4}\right.} \underline{\underline{\mathrm{mSv}} / \text { year })}$

Location of Maximally

Exposed Individual:

$\underline{427 \text { meters North/Northeast(Sand Hill Road) }}$

\subsection{Certification}

I certify under penalty of law that I have personally examined and am familiar with the information submitted herein, and based on my inquiry of those individuals immediately responsible for obtaining the information, I believe that the submitted information is true, accurate and complete. I am aware that there are significant penalties for submitting false information including the possibility of fine and imprisonment. (See 18 U.S.C. 1001.) 


\section{Additional Information}

As mentioned earlier in this report, all nine active SLAC research facilities had beam-on activities in calendar year 1999 (CY99). As is shown in section 3.3 of this report, even with all nine facilities powered-up, SLAC's potential emission of activated gases is extremely minor. At a calculated dose due to emissions of about three one-hundreths $(<0.0319)$ of a mrem per year, SLAC is below the ten mrem $(0.1$ mSv) NESHAPs annual threshold limit. In addition, there were no unplanned (emergency) releases of potentially activated radionuclides to contribute to the minute amounts that were calculated to have been emitted at SLAC.

\section{Supplemental Information}

- During CY99, the collective effective dose equivalent for the population within $80 \mathrm{~km}$ from SLAC 's site boundary ( 4,917,443 persons) was estimated to be $2.6 \times 10-1$ person-rem $(2.6 \times 10-3$ person-Sv).

- The reported source terms in the NESHAP's report for CY99 included all unmonitored sources that were identified at SLAC.

- Compliance with Subparts Q and T of 40 CFR Part 61 was not applicable at SLAC.

- Information on Rn-220 emissions from sources containing U-232 and Th-232 where emissions potentially could exceed $0.1 \mathrm{mrem}$ in one year to the public or $10 \%$ of the non-radon dose to the public was not applicable at SLAC.

- Information on non-disposal/non-storage sources of Rn-222 emissions where emissions potentially could exceed $0.1 \mathrm{mrem}$ in one year to the public or $10 \%$ of the non-radon dose to the public was not applicable at SLAC.

- SLAC did not have any emission points that contributed to more than $1 \%$ of the 10 mrem in one year ( $0.1 \mathrm{mSv}$ in one year) NESHAP's limit. Thus, continuous monitoring of these emission points was not required. 


\section{Calibration and Q uality Assurance Procedures}

The recording of natural background radiation provides continuous verification that the monitoring equipment at SLAC is connected and functioning properly. Also, backgrounds collected during accelerator downtimes and any interrupted operations provide additional information for establishing the calibration baseline.

\section{C.1 Direct Radiation Monitoring Equipment}

A regular calibration procedure was performed on the Peripheral Monitoring Stations in CY99. Radiation sources were placed at a measured distance from the detector to produce a known dose equivalent rate, for example, $1 \mathrm{mrem} / \mathrm{h}(0.01 \mathrm{mSv} / \mathrm{h})$.

The equipment is kept in normal operation during these checks. The data printout is marked so that the calibration data is not confused with actual measurements of machineproduced radiation. This procedure will be carried out at least once each year, and following any equipment repair or maintenance actions.

An appropriate response to natural background radiation provides evidence that the instruments are operating properly. An improved calibration program is under development.

\section{C.2 Liquid Radiological Effluents}

Water samples are analyzed in-house with a liquid scintillation counter and a hyper-pure germanium detector as necessary. Both pieces of equipment are calibrated with appropriate National Institute of Standards and Technology traceable sources. 


\section{Environmental TLD Measurements for CY99}

This appendix contains data on environmental thermoluminescent dosimeter (TLD) measurements for CY99, including:

- Summary of net photon and neutron doses for CY99.

- Environmental TLD Monitoring Stations (Table D-1).

Notes:

\begin{tabular}{|c|c|c|}
\hline TLD Type & $\begin{array}{c}\text { Nominal Minimum } \\
\text { Detectable Levels }\end{array}$ & Type of Radiation Detected \\
\hline $\begin{array}{c}\mathrm{Al}_{2} \mathrm{O}_{3}: \mathrm{C} \\
\text { (LDR-X9 Landauer Company) }\end{array}$ & $0.02 \mathrm{mrem}$ & Neutron \\
\hline $\begin{array}{c}\text { NeutrakER } \\
\text { (LDR-I9 Landauer Company) }\end{array}$ & $10 \mathrm{mrem}$ & \\
\hline
\end{tabular}


D-1 Net Annual Doses for CY99

\begin{tabular}{|c|c|c|c|c|}
\hline TLD Location & TLD \# & Net I & $\begin{array}{l}\text { oton D ose } \\
\text { rem) }\end{array}$ & $\begin{array}{c}\text { Net N eutron Dose } \\
\text { (mrem) }\end{array}$ \\
\hline Transport Control & - & & NA & $\mathrm{M}^{\mathrm{a}}$ \\
\hline Deployment Control & - & & NA & $M^{\mathrm{a}}$ \\
\hline SB at Region 6 & 1 & 4.0 & $+/-\quad 5.9$ & $\mathrm{M}^{\mathrm{a}}$ \\
\hline SB at Injector & 2 & 1.7 & $+/-\quad 6.0$ & $\mathrm{M}^{\mathrm{a}}$ \\
\hline Computer Center SE Corner & 3 & 0.9 & $+/-\quad 6.3$ & $M^{a}$ \\
\hline SB at Region 4 & 4 & 4.1 & $+/-\quad 6.1$ & $\mathrm{M}^{\mathrm{a}}$ \\
\hline SB at North Damping Ring & 5 & 16.9 & $+/-\quad 6.2$ & $\mathrm{M}^{\mathrm{a}}$ \\
\hline I-280 Overpass South & 6 & 8 & $+/-\quad 5.8$ & $\mathrm{M}^{\mathrm{a}}$ \\
\hline SB at Sector 10 south & 7 & 6.5 & $\begin{array}{ll}+/- & 7.2\end{array}$ & $\mathrm{M}^{\mathrm{a}}$ \\
\hline SB across from $\mathrm{B}$ of $\mathrm{A}$ & 8 & 4.4 & $+/-\quad 5.7$ & $\mathrm{M}^{\mathrm{a}}$ \\
\hline Alpine Gatehouse & 9 & 2.2 & $+/-\quad 6.3$ & $\mathrm{M}^{\mathrm{a}}$ \\
\hline Meteorological Tower & 10 & -0.6 & $+/-\quad 5.7$ & $\mathrm{M}^{\mathrm{a}}$ \\
\hline SB at SLD & 11 & 2.3 & $+/-\quad 5.8$ & $\mathrm{M}^{\mathrm{a}}$ \\
\hline SB at Region 12 & 12 & 5.8 & $\begin{array}{ll}+/- & 6.9\end{array}$ & $\mathrm{M}^{\mathrm{a}}$ \\
\hline SB at Region 2 & 13 & -6.4 & $+/-\quad 5.9$ & $\mathrm{M}^{\mathrm{a}}$ \\
\hline SLAC Entrance Gatehouse & 14 & 6.0 & $+/-\quad 6.0$ & $\mathrm{M}^{\mathrm{a}}$ \\
\hline SLAC Cafeteria & 15 & 9.8 & $+/-\quad 5.4$ & $\mathrm{M}^{\mathrm{a}}$ \\
\hline SB at Region 8 & 16 & -1.3 & $\begin{array}{ll}+/- & 6.8\end{array}$ & $\mathrm{M}^{\mathrm{a}}$ \\
\hline SB at Addison Wesley Building & 17 & 8.5 & $+/-\quad 6.2$ & $\mathrm{M}^{\mathrm{a}}$ \\
\hline SB at Positron Vault & 18 & 11.7 & $\begin{array}{ll}+/- & 5.7\end{array}$ & $\mathrm{M}^{\mathrm{a}}$ \\
\hline Control & 19 & 2.7 & $+/-\quad 6.6$ & $\mathrm{M}^{\mathrm{a}}$ \\
\hline SB at Sector 20 south & 20 & 7.8 & $+/-\quad 6.3$ & $\mathrm{M}^{\mathrm{a}}$ \\
\hline SB at South Damping Ring & 21 & -0.6 & $+/-\quad 6.5$ & $\mathrm{M}^{\mathrm{a}}$ \\
\hline I-280 Overpass North & 22 & 6.9 & $+/-\quad 5.9$ & $\mathrm{M}^{\mathrm{a}}$ \\
\hline SB at Sector 21 south & 23 & 7.0 & $+/-\quad 8.3$ & $\mathrm{M}^{\mathrm{a}}$ \\
\hline SB at building 81 & 24 & -10.1 & $+/-\quad 6.8$ & $\mathrm{M}^{\mathrm{a}}$ \\
\hline RAMSY & 25 & -13.1 & $+/-\quad 5.6$ & $\mathrm{M}^{\mathrm{a}}$ \\
\hline PMS 1 & 26 & 12.5 & $+/-\quad 6.1$ & $\mathrm{M}^{\mathrm{a}}$ \\
\hline PMS 2 & 27 & 5.0 & $+/-\quad 6.1$ & $\mathrm{M}^{\mathrm{a}}$ \\
\hline PMS 3 & 28 & 7.8 & $+/-\quad 6.2$ & $\mathrm{M}^{\mathrm{a}}$ \\
\hline PMS 4 & 29 & 1.9 & $+/-\quad 5.6$ & $\mathrm{M}^{\mathrm{a}}$ \\
\hline PMS 5 & 30 & 0.5 & $+/-\quad 6.0$ & $\mathrm{M}^{\mathrm{a}}$ \\
\hline PMS 6 & 31 & 14.8 & $+/-\quad 6.4$ & $\mathrm{M}^{\mathrm{a}}$ \\
\hline PMS 7 & 32 & 1.1 & $+/-\quad 5.8$ & $\mathrm{M}^{\mathrm{a}}$ \\
\hline SB at Sector 24 north & 33 & -3.8 & $+/-\quad 5.6$ & $\mathrm{M}^{\mathrm{a}}$ \\
\hline SB at Sector 17 north & 34 & 9.0 & $+/-\quad 5.6$ & $\mathrm{M}^{\mathrm{a}}$ \\
\hline SB at Sector 5 north & 35 & 30.3 & $+/-\quad 6.4$ & $\mathrm{M}^{\mathrm{a}}$ \\
\hline
\end{tabular}

a Below the minimum detection limit. 


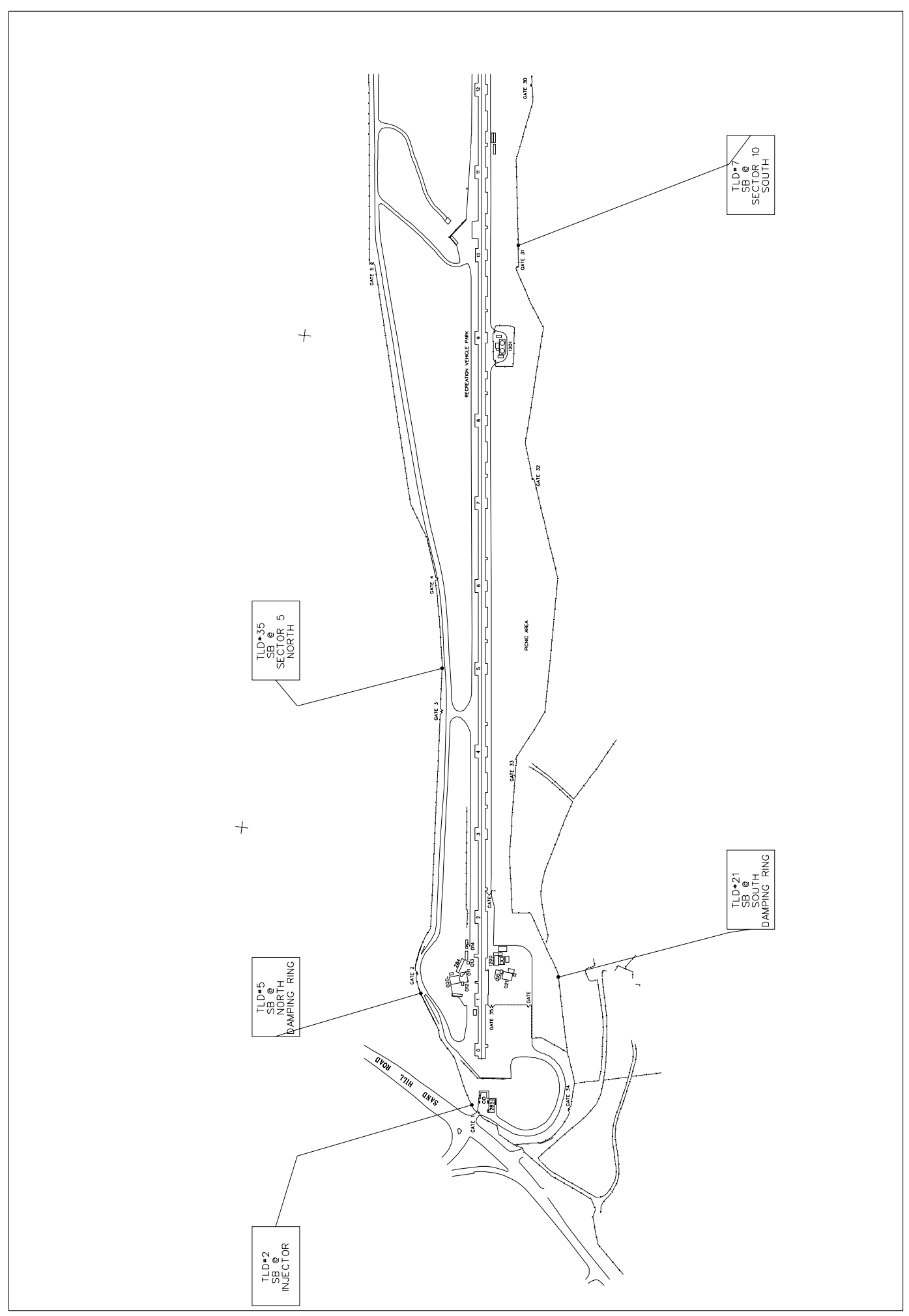

Figure D-1 Environmental TLD Monitoring Stations, Sectors 0 through 12 

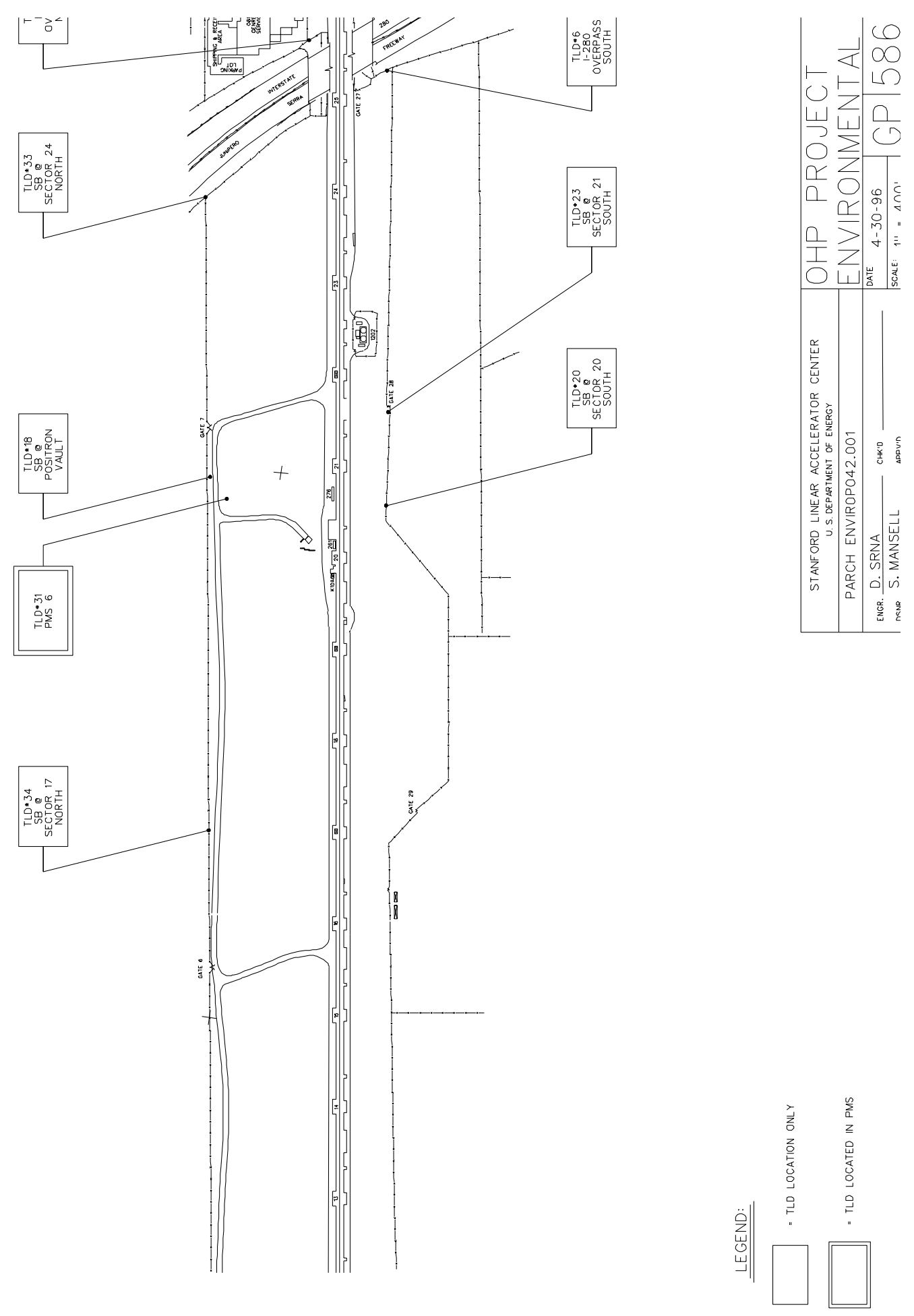

Figure D-2 Environmental TLD Monitoring Stations, Sectors 12 through 27 


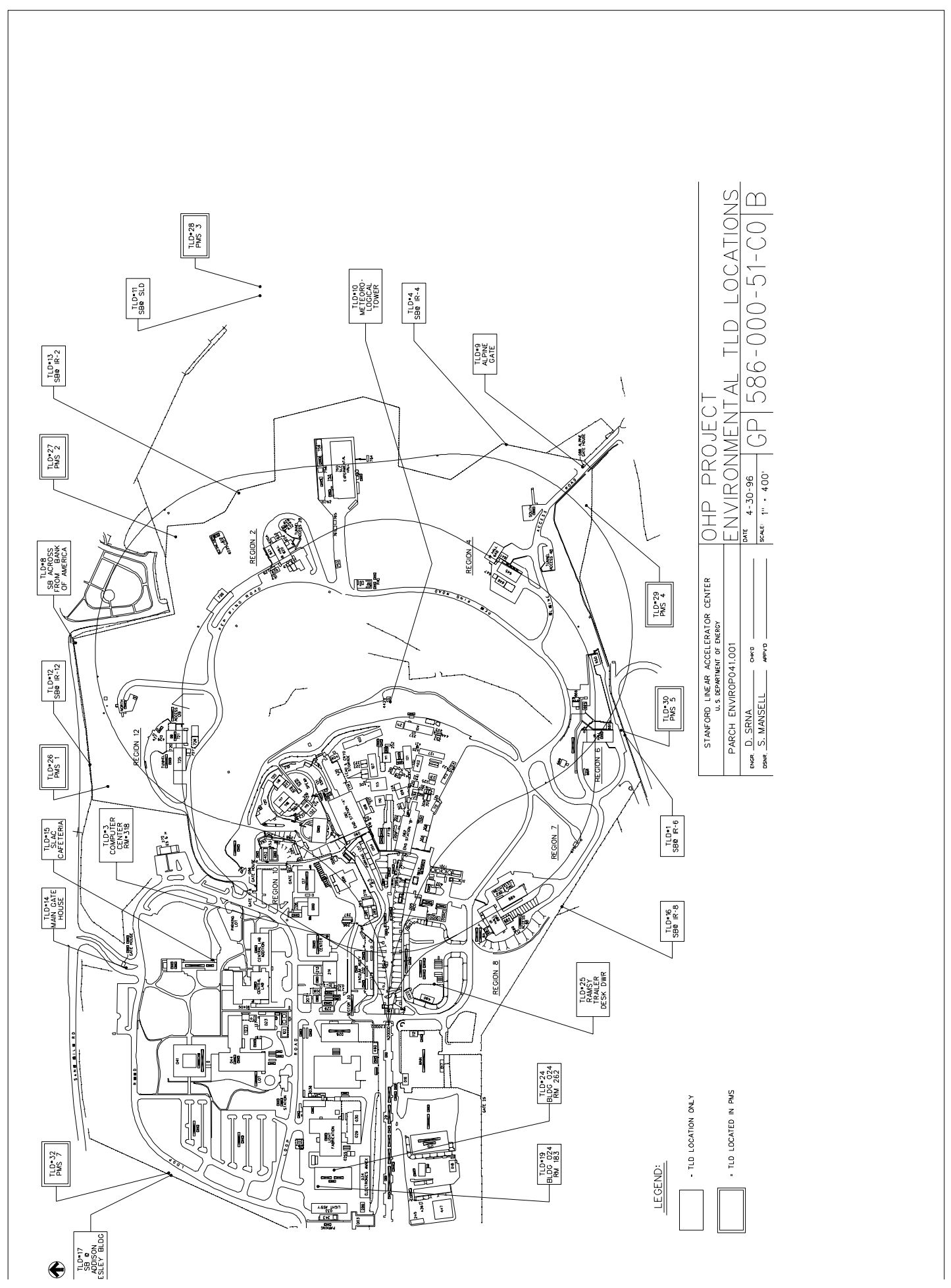

Figure D-3 Environmental TLD Monitoring Stations, Sector 27 through SLC 


\section{Acronym List}

A

ALARA As Low As Reasonably Achievable

B

BAAQ MD Bay Area Air Q uality Management District

BDE Beam Dump East

BMP Best M anagement Practice

BPO Basin Plan Objective

BSY Beam Switchyard

BTP Batch Treatment Plant

C

CAA Clean Air Act

CalARP California Accidental Release Prevention Program

CERCLA Comprehensive Environmental Response, Compensation, and Liability Act

CEQ A California Environmental Q uality Act

CHWMA Central Hazardous W aste Management Area

COE Army Corp of Engineers

CPM Counts Per Minute

CRMP Comprehensive Resource Management and Planning

CW A Clean Water Act

CX Categorical Exclusion

CY Calendar Year

D

DCE Dichloroethene

DCG Derived Concentration Guide

DEAR DOE Acquisition Regulations

DFG Department of Fish and Game

DOE Department of Energy

DOE/OAK DOE O akland O perations O ffice

E

EA Environmental Assessment

EC Electrical Conductivity

EDE Effective Dose Equivalent 


\begin{tabular}{|c|c|}
\hline EEECA & Engineering Evaluation and Cost Analysis \\
\hline EIS & Environmental Impact Statement \\
\hline EPA & Environmental Protection Agency \\
\hline EPCRA & Emergency Planning and Community Right-to-Know Act \\
\hline EML & Environmental M easurements Laboratory \\
\hline EMSL-LV & Environmental M onitoring Systems Laboratory- Las Vegas \\
\hline EPR & Environmental Protection and Restoration \\
\hline ERP & Environmental Restoration Program \\
\hline ES\&H & Environment, Safety, and Health \\
\hline $\mathrm{ESA}_{2}$ & End Station A \\
\hline $\mathrm{ESA}_{1}$ & Endangered Species Act \\
\hline ESHCC & Environment, Safety, and Health Coordinating Council \\
\hline \multicolumn{2}{|l|}{$\mathbf{F}$} \\
\hline FEMA & Federal Emergency M anagement Agency \\
\hline FFS & Final Focus System \\
\hline FFTB & Final Focus Test Beam \\
\hline FHW SA & Former Hazardous W aste Storage Area \\
\hline FIFRA & Federal Insecticide, Fungicide, and Rodenticide Act \\
\hline FMS & Flow Meter Station \\
\hline FSU ST & Former Solvent U nderground Storage Tank \\
\hline FUST & Former U nderground Storage Tank \\
\hline \multicolumn{2}{|l|}{$\mathbf{G}$} \\
\hline G PMP & Groundwater Protection M anagement Program \\
\hline G PP & General Plant Project \\
\hline \multicolumn{2}{|l|}{ H } \\
\hline HMBP & H azardous M aterials Business Plan \\
\hline HPGe & H yper-pure G ermanium \\
\hline HWMC & H azardous W aste and M aterial Coordinator \\
\hline HWMG & H azardous W aste Management G roup \\
\hline \multicolumn{2}{|l|}{ I } \\
\hline IR & Interaction Region \\
\hline IRA & Interim Removal Action \\
\hline \multicolumn{2}{|l|}{$K$} \\
\hline kWh & kilowatt-hour \\
\hline \multicolumn{2}{|l|}{$\mathbf{L}$} \\
\hline LA & Local Authority \\
\hline LCW & Low Conductivity Water \\
\hline linac & Linear Accelerator \\
\hline LSC & Liquid Scintillation Counter \\
\hline
\end{tabular}


M

MCC Main Control Center

MCL Maximum Concentration Level

MEI Maximally Exposed Individual

MFD Mechanical Fabrication Department

MPMWD Menlo Park Municipal W ater Department

MW mega-watt

N

NCP National O il and Hazardous Substances Pollution Contingency Plan

NEPA National Environmental Policy Act

N ESH APS N ational Emission Standards for Hazardous Air Pollutants

NHPA National Historic Preservation Act

NIST N National Institute of Standards and Technology

NLC N ext Linear Collider

NLCTA N ext Linear Collider Test Accelerator

NOI Notice of Intent

NOX Nitrogen Oxides

N PDES N National Pollutant D ischarge Elimination System

N PL N National Priorities List

NVLAP National Voluntary Laboratory Accreditation Program

0

ODS Ozone-D epleting Substance

OHP O perational Health Physics

$\mathbf{P}$

PCB Polychlorinated Biphenyl

PCi/I Pico-curies per Liter

PED Plant Engineering Department

PEL Physical Electronics Laboratory

PEP Positron-Electron Project

PEP-II Asymmetric B Factory

PMS Peripheral Monitoring Station

ppb parts per billion

ppm parts per million

POTW Publicly O wned Treatment W orks

PPO Program Planning Office

PS Positron Source 
Q

$\begin{array}{ll}\text { Q A } & \text { Quality Assurance } \\ \text { Q AP } & \text { Quality Assessment Program } \\ \text { QC } & \text { Quality Control }\end{array}$

$\mathbf{R}$

RCRA Resource Conservation and Recovery Act

RI Remedial Investigation

RI/FS Remedial Investigation/Feasibility Study

RMP Risk Management Plan

ROI Return-on-Investment

RP Radiation Physics

RQ Reportable Quantity

RW Q CB Regional Water Q uality Control Board

RWTP Rinse W ater Treatment Plant

S

S\&E

Safety and Environmental

SARA Superfund Amendments and Reauthorization Act

SBSA South Bayside System Authority

SD W A Safe D rinking Water Act

SER Site Environmental Report

SHA Safety, Health, and Assurance

SLAC Stanford Linear Accelerator Center

SLC Stanford Linear Collider

SLD SLAC Large D etector

SMC/DHS San Mateo County Department of Health Services

SMS Safety M anagement System

SPCC Spill Prevention, Control, and Countermeasure Plan

SPEAR Stanford Positron-Electron Asymmetric Ring

SSRL Stanford Synchrotron Radiation Laboratory

Sv Sievert

SW PPP Storm W ater Pollution Prevention Plan

$\mathbf{T}$

TCA

TCE

Trichloroethane

TDS

Trichloroethene

TLD

TPH

Total Dissolved Solids

Thermoluminescent D osimeter

TRI

Total Petroleum Hydrocarbons

TSCA

Toxic Release Inventory

TSDF

Toxic Substances Control Act

TSS

Treatment, Storage, and Disposal Facility

TTO

Total Suspended Solids

Total Toxic Organics 
U

U SEPA US Environmental Protection Agency

V

VOC Volatile O rganic Compound

W

WAA Waste Accumulation Area

WBSD West Bay Sanitary District

WSS Work Smart Standards

WM Waste Management

WTS Waste Tracking System 


\title{
ASER D istribution List
}

\author{
Bill Griffin \\ Head, \\ Environment, Safety, and Health Section \\ Fermi N ational Accelerator Laboratory MS 119 \\ P.O. Box 500 \\ Batavia, IL 60510 \\ District M anager \\ West Bay Sanitary District \\ 500 Laurel Street \\ Menlo Park, CA 94025 \\ Rebecca Failor \\ ES\&H Team 3 Division Leader \\ L-143 \\ P.O. Box 808 \\ Lawrence Livermore National Laboratory \\ Livermore, CA 94551 \\ Paul Frame \\ TM SD/PTP \\ O RISE \\ PO Box 117 \\ O ak Ridge, TN 37830 \\ Steve H su \\ State of California \\ Department of Health Services \\ Radiological Health Branch \\ P.O. Box 942732 \\ Sacramento, CA 95634-7320 \\ Bill Klokke \\ South Bayside System Authority \\ 1400 Radio Road \\ Redwood City, CA 94065 \\ Leslie Laudon \\ State Water Resources Control Board \\ Division of Clean Water Programs \\ P.O. Box 94412 \\ Sacramento, CA 95834-2120
}


William Lent

San Mateo Department of H ealth Services

O ffice of Environmental Health

County $O$ ffice Building

590 Hamilton Street

Redwood City, CA 94063

Librarian

Oak Ridge N ational Laboratory

Technical Information Center

O ak Ridge, TN 37830

Felicia Marcus

U.S. Environmental Protection Agency

Region IX

75 Haw thorne

San Francisco, CA 94105

Bob May

Head

TJNAL/SURA Radiation Control Group

Mail Stop 12 A 1

12000 Jefferson Avenue

Newport News, VA 23606

John Muhlestein

U.S. Department of Energy

$O$ akland $O$ perations $O$ ffice

Stanford Site O ffice

Stanford Linear Accelerator Center

P.O. Box $4349 \mathrm{M} / \mathrm{S} 8 \mathrm{~A}$

Stanford, CA 94309

John B. Murphy

Environmental Coordinator

$\mathrm{O}$ ak Ridge $\mathrm{N}$ ational Laboratory

Building 4500N, MS 6198

O ak Ridge, TN 37831

Ross N atoli

U.S. Department of Energy, ES-412

Forrestal Building, Room 3G-089

1000 Independence Avenue, S.W.

Washington D.C. 20585

Charles NeSmith

State Water Resources Control Board

Division of Clean Water Programs

Solid Waste Assessment Test U nit

P.O. Box 944212

Sacramento, CA 94244-2120 
James N usrala

California Regional Water Q uality Control Board

San Francisco Bay Region

1515 Clay Street

O akland, CA 94612

OSTI

U.S. Department of Energy O ffice of Scientific and Technical Information

P.O. Box 62

O ak Ridge, Tennessee 37831

Phil Rutherford

Manager, Radiation Safety

Rocketdyne Propulsion \& Power

The Boeing Company

6633 Canoga Ave.

P. O. Box 7922 (M S T487)

Canoga Park, CA 91309-7922

John Semerau

Bay Area Air Q uality M anagement District

939 Ellis Street

San Francisco, CA 94109

Annette Walton

Stanford M anagement Company

2770 Sand Hill Road

M enlo Park, CA 94025 